"CORRUPTION AND INTERNAL FRAUD IN

TURKISH CONSTRUCTION INDUSTRY"

OYTUN ÖNDER

AUGUST 2011 


\section{"CORRUPTION AND INTERNAL FRAUD IN}

TURKISH CONSTRUCTION INDUSTRY"

\section{A THESIS SUBMITTED TO}

THE GRADUATE SCHOOL OF NATURAL AND APPLIED SCIENCES $\mathrm{OF}$

MIDDLE EAST TECHNICAL UNIVERSITY

BY

OYTUN ÖNDER

IN PARTIAL FULFILLMENT OF THE REQUIREMENTS

FOR

THE DEGREE OF MASTER OF SCIENCE

IN

CIVIL ENGINEERING

AUGUST 2011 
Approval of the thesis:

\section{“CORRUPTION AND INTERNAL FRAUD IN TURKISH CONSTRUCTION INDUSTRY"}

submitted by OYTUN ÖNDER in partial fulfillment of the requirements for the degree of Master of Science in Civil Engineering Department, Middle East Technical University by,

Prof. Dr. Canan Özgen

Dean, Graduate School of Natural and Applied Sciences

Prof. Dr. Güney Özcebe

Head of Department, Civil Engineering

Assoc. Prof. Dr. Murat Gündüz

Supervisor, Civil Engineering Department, METU

\section{Examining Committee Members:}

Prof. Dr. M. Talat Birgönül

Civil Engineering Department, METU

Assoc. Prof. Dr. Murat Gündüz

Civil Engineering Department, METU

Prof. Dr. Irem Dikmen Toker

Civil Engineering Department, METU

Assoc. Prof. Dr. Rifat Sönmez

Civil Engineering Department, METU

Gonca Okur Buffington

Manager, Ernst and Young

Date: $\quad 12 / 08 / 2011$ 
I hereby declare that all information in this document has been obtained and presented in accordance with academic rules and ethical conduct. I also declare that, as required by these rules and conduct, I have fully cited and referenced all material and results that are not original to this work.

Name, Last name: Oytun ÖNDER

Signature: 


\title{
ABSTRACT \\ CORRUPTION AND INTERNAL FRAUD IN \\ TURKISH CONSTRUCTION INDUSTRY
}

\author{
Önder, Oytun \\ M.Sc., Department of Civil Engineering \\ Supervisor: Assoc. Prof. Dr. Murat Gündüz
}

August 2011, 155 pages

The purpose of this thesis is to develop an understanding about internal fraud and corruption problem in Turkish construction industry. During the research, the reasons behind the internal fraud and corruption problem, types of internal fraud and prevention methods for internal fraud and corruption were investigated and various recommendations were developed. Moreover, fraud risk awareness questionnaire was implemented to understand the likelihood occurrence of internal fraud types in construction sector and proactive and reactive measures against these problems. Moreover, types of fraud incidences experienced by Turkish construction companies were also investigated with the questionnaire. The questionnaire reached to 89 respondents and, recommendations to prevent internal fraud and corruption problem were developed by detailed statistical analyses.

Keywords: Corruption, Internal Fraud 


\title{
Öz
}

\section{TÜRK INNȘAAT İSSLERINNDE \\ YOLSUZLUK VE İÇ USULSÜZLÜK}

\author{
Önder, Oytun \\ Yüksek Lisans, İnşaat Mühendisliği Bölümü \\ Tez Yöneticisi: Doç. Dr. Murat Gündüz
}

Ağustos 2011, 155 sayfa

Bu tezin amacı, Türkiye'de inşaat sektörünün iç usulsüzlük ve yolsuzluk problemi ile ilgili bir bakış açısı oluşturmaktır. Araştırma kapsamında, iç usulsüzlük ve yolsuzluk problemlerini oluşturan nedenler, iç usulsüzlük türleri ve iç usulsüzlük ve yolsuzluk problemlerini önleme yöntemleri incelenmiş, çeşitli öneriler geliştirilmiştir. Ayrıca, inşaat sektöründe yaygın olarak karşılaşılan iç usulsüzlük yöntemleri ve bu yöntemlere karşı inşaat sökteründe kullanılan proaktif ve reaktif önlemlerin tespit edilebilmesi için usulsüzlük riski farkındalık anketi oluşturulmuş ve uygulanmıştır. Bunların yanı sıra ankette, Türk inşaat şirketlerinin başlarına gelen usulsüzlük vakaları araştırılmıştır. Bu anket, 89 kişi tarafından doldurulmuş ve anketin detaylı istatistiki analizi ışığında iç usulsüzlük ve yolsuzluk problemlerini önleme konusunda öneriler geliştirilmiştir.

Anahtar Kelimeler: Yolsuzluk, İç usulsüzlük 


\section{ACKNOWLEDGEMENTS}

The author wishes to express his deepest gratitude to his supervisor Assoc. Prof. Dr. Murat GÜNDÜZ for his guidance, advice, criticism, encouragements and insight throughout the research.

I would like to thank all of the people for their contributions which helped the study. Especially to my colleagues, Gonca Buffington, Çağlar Kirik and Ekin İlhan for sharing their ideas and time for me and my friend, Onur Erdoğan, for sharing his statistical knowledge with me.

I would like to thank TUBITAK for supporting me as a scholar during my graduate education.

I would also like to thank my parents and my sister. They always supported and encouraged me with their best wishes.

Finally, I would like to thank my wife, Seçil Akdemir Önder. She was always there cheering me up and stood by me through the good times and bad. 


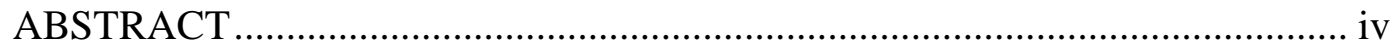

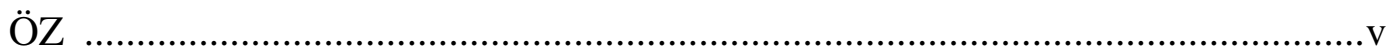

ACKNOWLEDGEMENTS ........................................................................ vi

TABLE OF CONTENTS ........................................................................... vii

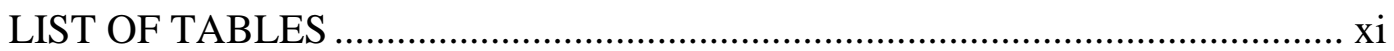

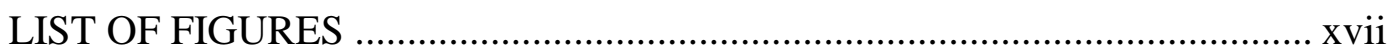

LIST OF ABBREVIATIONS …................................................................ xviii

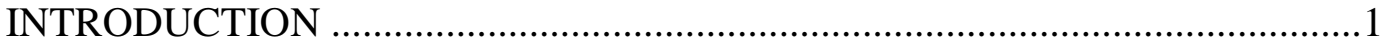

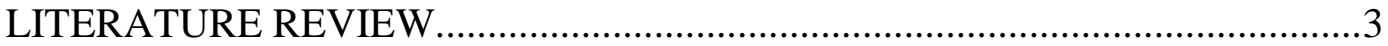

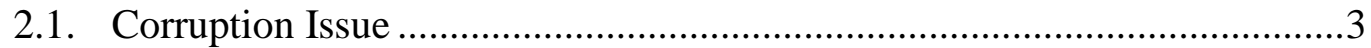

2.1.1. Corruption Issue in Construction Industry ................................................. 3

2.1.2. Magnitude, Results and Future of The Corruption Problem in

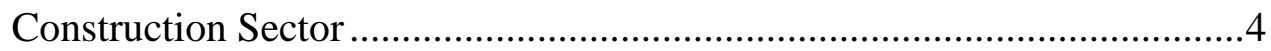

2.2. Parties in Corruption and Potentially Corrupted Acts..................................5

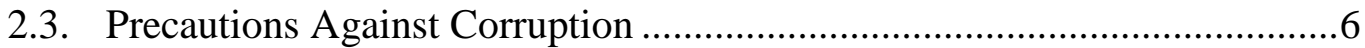

2.3.1. Methods For Preventing Corruption .......................................................6

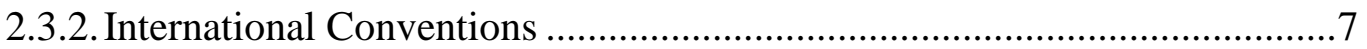

2.3.3. Precautions Developed By Federations, Institutions and

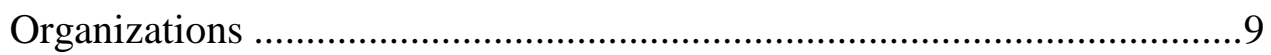

2.3.3.1. International Federation of Consulting Engineers ............................... 9

2.3.3.2. World Economic Forum ….............................................................10

2.3.3.3. The World Federation of Engineering Organizations...........................10

2.3.3.4. Global Infrastructure Anti Corruption Centre ....................................10

2.3.3.5. Civil Engineering Institutions and Associations..................................10

2.3.3.6. International Federation of Accountants.............................................11

2.4. Corruption Problem in Turkey ......................................................................11 
2.4.1. Turkey`s Legal Status Against Corruption.

2.5. International Surveys Related to Internal Fraud and Corruption

2.5.1. Report to The Nations on Occupational Fraud and Abuse

Performed By Association of Certified Fraud Examiners .........................15

2.5.2. Ernst and Young's $11^{\text {th }}$ Global Fraud Survey ..........................................16

2.5.3.EY's European Fraud Survey, 2009........................................................19

2.5.4. Pricewaterhousecoopers`s Engineering and Construction Part of Global Economic Crime Survey, 2010 ................................................21

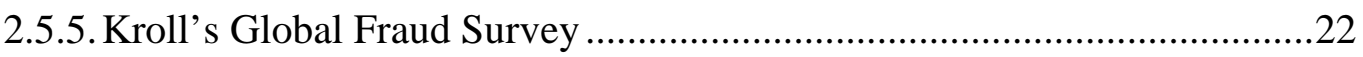

2.5.6. KPMG's Global Construction Survey, 2010............................................24

2.5.7. KPMG's Global Construction Survey, 2005...........................................24

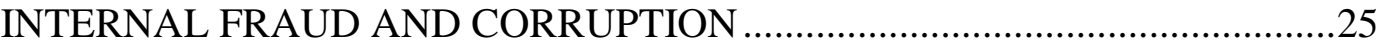

3.1. The Definition and Description of Fraud .............................................25

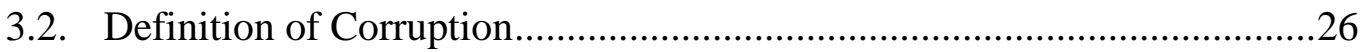

3.3. Main Differences between Fraud and Corruption.....................................26

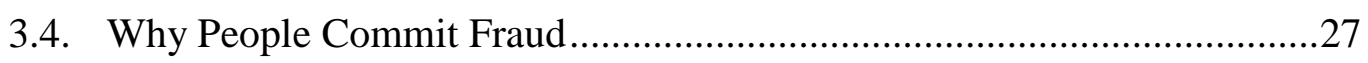

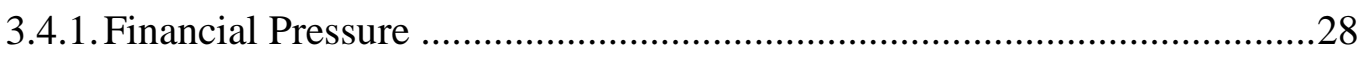

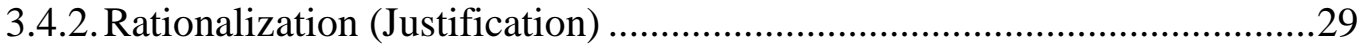

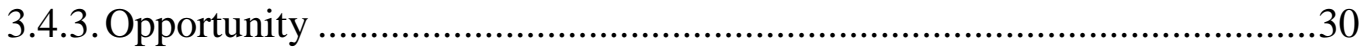

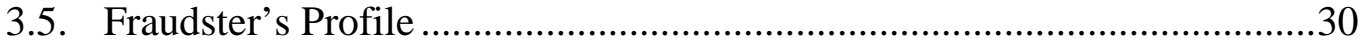

3.6. Internal and External Indicators of Fraud Risks........................................32

3.6.1. Internal Indicators of Fraud Risks - Company Structure ............................32

3.6.2. Internal Indicators of Fraud Risks - Employee Behaviors..........................33

3.6.3. External Indicators - Market Conditions ....................................................34

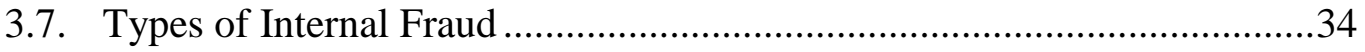

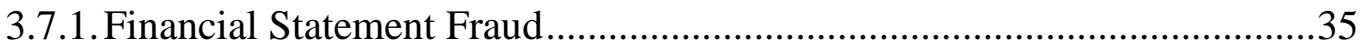

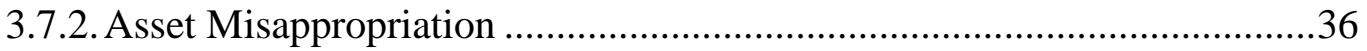

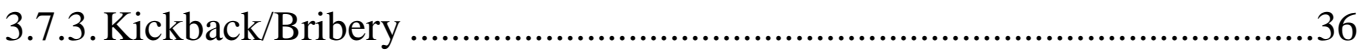

3.7.3.1. Fraud Schemes in Vendor Selection through Negotiation

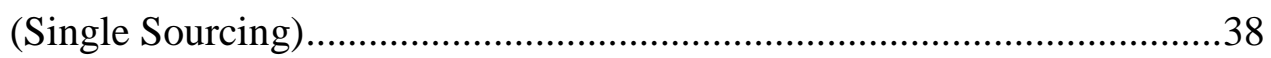


3.7.3.2. Fraud Schemes in Competitive Bidding Process.

3.7.3.2.1. Bid Rigging in Pre-solicitation Phase .............................................40

3.7.3.2.2. Bid Rigging in Solicitation-Negotiation Phase ...............................41

3.7.3.2.3. Bid Rigging in Submission Phase ...............................................42

3.7.3.3. Reasons for Not Preventing Kickback/Bribery Schemes ...................43

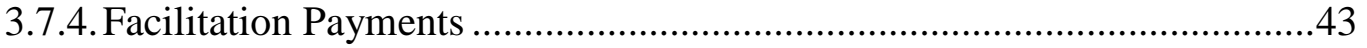

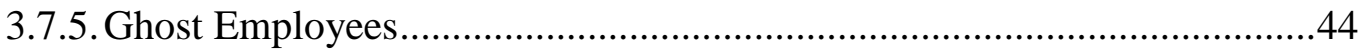

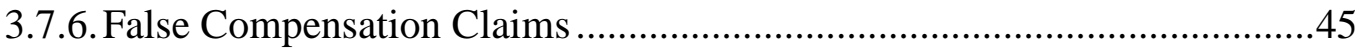

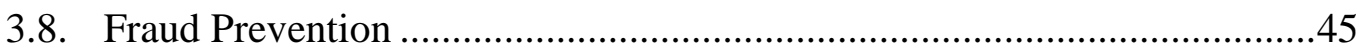

3.8.1. Segregation of Duties Principle ............................................................. 45

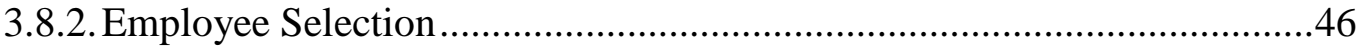

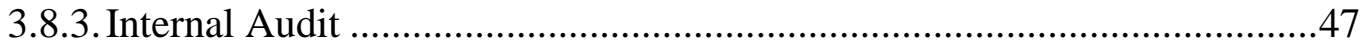

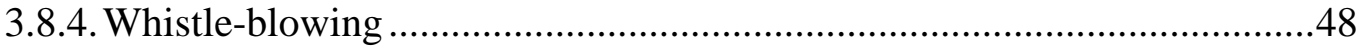

3.8.5. Code of Ethics and Code of Business Conduct ..........................................50

3.8.6. Periodic Vendor Contract Reviews .........................................................51

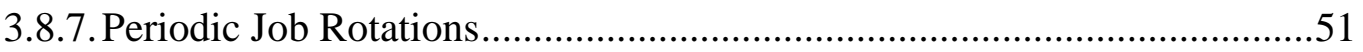

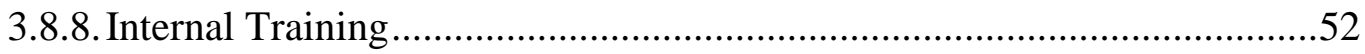

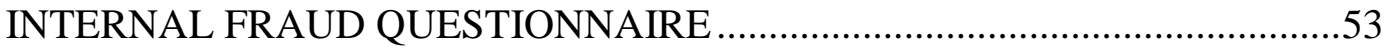

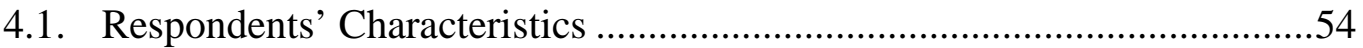

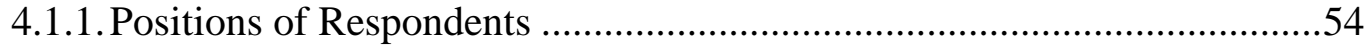

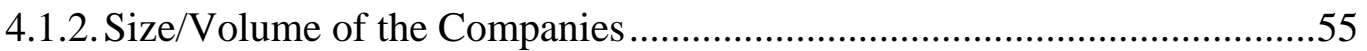

4.1.3. Type and Place of Contracts and Expertise Areas of the Companies ........58

4.1.4. Fraud Risk Awareness of the Respondents ...............................................60

4.1.5. Wrongdoings on Behalf of The Company ................................................64

4.1.6. Fraud Prevention Status of the Companies ...............................................66

4.1.7. Internal Fraud Cases and Responsive Actions ..........................................70

4.1.8. Important Results From The Fraud Awareness Survey ............................73

STATISTICAL ANALYSES OF THE FRAUD SURVEY …............................75

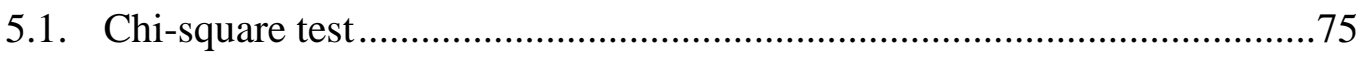

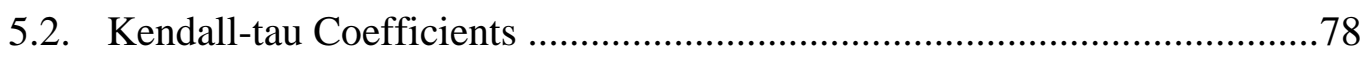


5.3. Testing the Relationships between Variables...........................................8

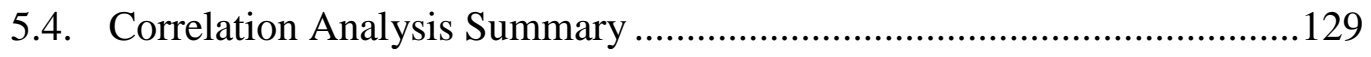

RECOMMENDATION TO CONSTRUCTION PROFESSIONALS ................152

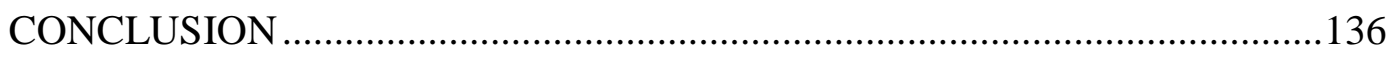

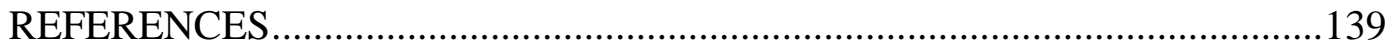

APPENDICES

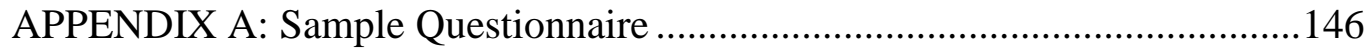




\section{LIST OF TABLES}

\section{TABLES}

Table 1: Most significant compliance issues .................................................. 17

Table 2: Most effective fraud prevention methods ............................................ 18

Table 3: Best mechanisms to detect frauds sooner ........................................... 18

Table 4: Fraud prevention methods used by the companies .............................. 20

Table 5: Justifiable actions in order to survive business.................................... 21

Table 6: Types of internal fraud in construction sector ................................... 23

Table 7: Areas those companies invest in order to prevent fraud ........................ 23

Table 8: Main conceptual differences between fraud and corruption.................. 27

Table 9: Positions of the respondents ................................................................... 54

Table 10: Number of employees working in the headquarters of the Companies'

Table 11: Annual average revenues of the Companies (Average of last three years)

Table 12: Main types of contracts signed by the Companies (in the last three years) 58

Table 13: Number of expertise areas of the Companies 59

Table 14: The Companies that performed construction projects abroad 60

Table 15: Respondents think the Companies are under the risk of fraud 60

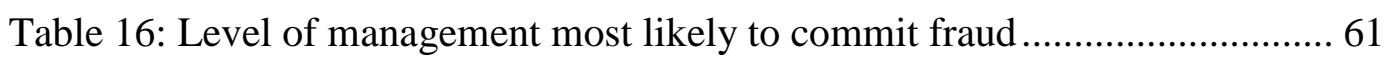

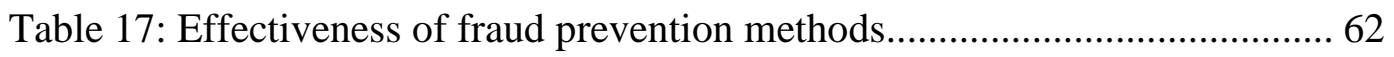

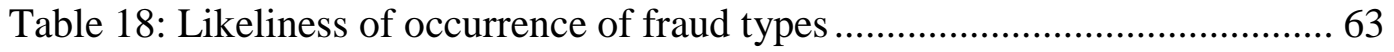

Table 19: The Companies that permit facilitation payments .............................. 64

Table 20: Wrongdoings perceived as acceptable during an economic crisis........ 65

Table 21: The soonest date of fraud risk assessment on the Companies .............. 66

Table 22: Fraud prevention methods used by the Companies ............................. 68

Table 23: Controls applied during vendor selection/purchase process .................69 69 
Table 24: Controls applied during employee selection.

Table 25: The Companies experienced internal fraud cases .............................. 71

Table 26: Types of fraud cases experienced by the Companies ......................... 72

Table 27: Actions of the Companies after experiencing internal fraud cases....... 73

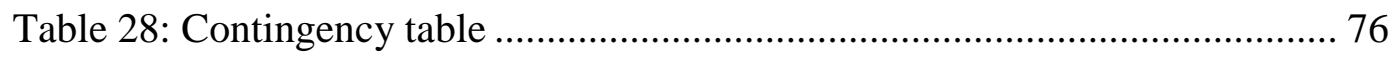

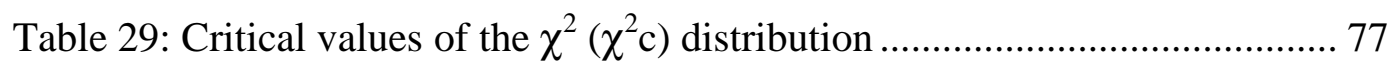

Table 30: Contingency table of the Companies performed construction

projects abroad vs. importance level of management reviews according to

respondents.

Table 31: Cross tabular of the Companies performed construction projects

abroad vs. importance level of management reviews according to

respondents.

Table 32: Kendall-tau tests for the Companies performed construction

projects abroad vs. importance level of management reviews according to respondents.

Table 33: The variables and expected associations.

Table 34: Contingency table of performing projects abroad and thinking that

the Company is under fraud risk

Table 35: Chi Square tests for correlation between performing projects

abroad and thinking that the Company is under fraud risk

Table 36: Kendall-tau tests for association between performing projects

abroad and thinking that the Company is under fraud risk

Table 37: Contingency table of the annual revenue of the Company and

having code of business conduct

Table 38: Chi Square tests for correlation between the annual revenue of the

Company and having code of business conduct

Table 39: Kendall-tau tests for the annual revenue of the Company and having code of business conduct.

Table 40: Contingency table of the number of employees and having code of business conduct 91 
Table 41: Chi Square tests for correlation between the number of employees and having code of business conduct

Table 42: Kendall-tau tests for the number of employees and having code of business conduct

Table 43: Contingency table of the number of employees and getting external audit services

Table 44: Chi Square tests for correlation between the number of employees and getting external audit services

Table 45: Kendall-tau tests for the number of employees and getting external audit services

Table 46: Contingency table of the annual revenue of the Company and having internal audit function 95

Table 47: Chi Square tests for correlation between the annual revenue of the Company and having internal audit function

Table 48: Kendall-tau tests for the annual revenue of the Company and having internal audit function

Table 49: Contingency table of the number of employees and having list of qualified/selected vendors .

Table 50: Chi Square tests for correlation between the number of employees and having list of qualified/selected vendors 98

Table 51: Kendall-tau tests for the number of employees and having list of qualified/selected vendors.

Table 52: Contingency table of the annual revenue of the Company and having list of qualified/selected vendors.....

Table 53: Chi Square tests for correlation between the annual revenue of the Company and having list of qualified/selected vendors

Table 54: Kendall-tau tests for the annual revenue of the Company and having list of qualified/selected vendors.

Table 55: Contingency table of the annual revenue of the Company and having requirements to obtain bids from multiple vendors 
Table 56: Chi Square tests for correlation between the annual revenue of the Company and having requirements to obtain bids from multiple vendors

Table 57: Kendall-tau tests for the annual revenue of the Company and having requirements to obtain bids from multiple vendors

Table 58: Contingency table of the annual revenue of the Company and having segregated purchase order and vendor selection functions 104

Table 59: Chi Square tests for correlation between the annual revenue of the Company and having segregated purchase order and vendor selection function

Table 60: Kendall-tau tests for the annual revenue of the Company and having segregated purchase order and vendor selection functions

Table 61: Contingency table of the number of employees and verification of education and certificate information of job applicants 106

Table 62: Chi Square tests for correlation between the number of employees and verification of education and certificate information of job applicants

Table 63: Kendall-tau tests for the number of employees and verification of education and certificate information of job applicants

Table 64: Contingency table of experiencing a fraud case and thinking that the Company is under fraud risk 108

Table 65: Chi Square tests for correlation between experiencing a fraud case and thinking that the Company is under fraud risk

Table 66: Kendall-tau tests for experiencing a fraud case and thinking that the Company is under fraud risk

Table 67: Contingency table of the annual revenue of the Company and being victim of internal fraud.

Table 68: Chi Square tests for correlation between the annual revenue of the Company and being victim of internal fraud

Table 69: Contingency table of the number of expertise areas and being victim of internal fraud 
Table 70: Chi Square tests for correlation between the number of expertise areas and being victim of internal fraud

Table 71: Contingency table of performing projects abroad and being victim of internal fraud

Table 72: Chi Square tests for correlation between performing projects abroad and being victim of internal fraud

Table 73: Contingency table of having internal audit services in place and being victim of internal fraud

Table 74: Chi Square tests for correlation between having internal audit services in place and being a victim of internal fraud.

Table 75: Contingency table of checking the references of job applicants and being victim of internal fraud..... 116

Table 76: Chi Square tests for correlation between checking the references of job applicants and being victim of internal fraud

Table 77: Kendall-tau tests for checking the references of job applicants and being victim of internal fraud

Table 78: Contingency table of permitting/encouraging facilitation

payments and being victim of internal fraud

Table 79: Chi Square tests for correlation between permitting/encouraging facilitation payments and being victim of internal fraud

Table 80: Kendall-tau tests for permitting/encouraging facilitation payments and being victim of internal fraud

Table 81: Contingency table of organizing entertainments for employers for the survival of your company and being victim of internal fraud

Table 82: Chi Square tests for correlation organizing entertainments for employers for the survival of your company and being victim of internal fraud

Table 83: Contingency table of bribe employers for the survival of the Company and being victim of internal fraud 
Table 84: Chi Square tests for correlation between giving presents to employers for the survival of the Company and being victim of internal fraud

Table 85: Kendall-tau tests for giving presents to employers for the survival of the Company and being victim of internal fraud

Table 86: Contingency table of bribing employers for the survival of the Company and being victim of internal fraud

Table 87: Chi Square tests for correlation bribing employers for the survival of the Company and being victim of internal fraud

Table 88: Contingency table of permitting/encouraging facilitation

payments and being victim of "Misuse of an Inventory"

Table 89: Chi Square tests for correlation permitting/encouraging facilitation payments and being victim of "Misuse of an Inventory" 126

Table 90: Kendall-tau tests for permitting/encouraging facilitation payments and being victim of "Misuse of an Inventory".

Table 91: Contingency table of permitting/encouraging facilitation payments and being victim of "Cash Theft"

Table 92: Chi Square tests for correlation between permitting/encouraging facilitation payments and being victim of "Cash Theft".

Table 93: Kendall-tau tests for permitting/encouraging facilitation payments and being victim of "Cash Theft"

Table 94: Correlation analysis summary..... 


\section{LIST OF FIGURES}

\section{FIGURES}

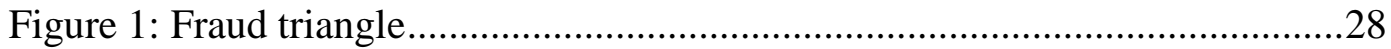

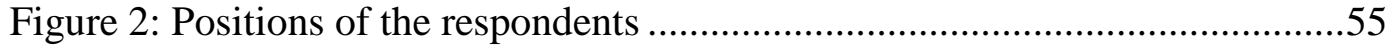

Figure 3: Number of employees working in the headquarters of the

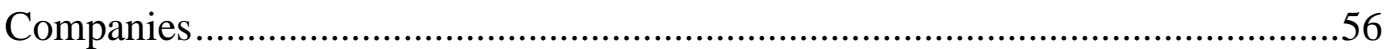

Figure 4: Annual average revenues of the Companies.......................................57

Figure 5: Respondents think the companies are under the risk of fraud ................61

Figure 6: The Companies that permit facilitation payments ................................64

Figure 7: The soonest date of fraud risk assessment on the Companies ...............67

Figure 8: Fraud prevention methods used by the Companies ...............................68

Figure 9: The Companies experienced internal fraud cases...............................71 


\section{LIST OF ABBREVIATIONS}

\begin{tabular}{|c|c|}
\hline ACFE & : Association of Certified Fraud Examiners \\
\hline ASCE & : American Society of Civil Engineers \\
\hline ASOSAI & : Asian Organization of Supreme Audit Institutions \\
\hline $\mathrm{B}$ & : Billion \\
\hline BIMS & : Business Integrity Management System \\
\hline $\mathrm{CEO}$ & : Chief Executive Officer \\
\hline CFE & : Certified Fraud Examiner \\
\hline $\mathrm{CFO}$ & : Chief Financial Officer \\
\hline CIMA & : The Chartered Institute of Management Accountants \\
\hline CPI & : Corruption Perception Index \\
\hline $\mathrm{DF}$ & : Degrees of Freedom \\
\hline EU & : European Union \\
\hline $\mathrm{EV}$ & : Expected Value \\
\hline EY & : Ernst and Young \\
\hline FIDIC & : International Federation of Consulting Engineers \\
\hline GIACC & : Global Infrastructure Anti Corruption Center \\
\hline HVAC & : Heating Ventilating and Air Conditioning \\
\hline IFAC & : International Federation of Accountants \\
\hline IIA & : Institute of Internal Auditors \\
\hline IT & : Information Technology \\
\hline IP & : Intellectual Property \\
\hline K & : Thousand \\
\hline $\mathrm{M}$ & : Million \\
\hline MASAK & : Financial Crimes Investigation Board \\
\hline OECD & : Organization for Economic Cooperation and \\
\hline & Development \\
\hline
\end{tabular}




$\begin{array}{ll}\text { OV } & : \text { Observed Value } \\ \text { PACI } & : \text { Partnering against Corruption Initiative } \\ \text { PWC } & : \text { Pricewaterhousecoopers } \\ \text { QA/QC } & : \text { Quality Assurance/Quality Control } \\ \text { SAS } & : \text { Statement on Auditing Standards } \\ \text { SPSS } & : \text { Statistical Package for Social Sciences } \\ \text { TI } & : \text { Transparency International } \\ \text { TL } & : \text { Turkish Lira } \\ \text { UK } & : \text { United Kingdom } \\ \text { UN } & : \text { United Nations } \\ \text { USA } & : \text { United States of America } \\ \text { USD } & : \text { World Economic Forum } \\ \text { WEF } & : \text { The World Federation of Engineering Organizations } \\ \text { WFEO } & \end{array}$




\section{CHAPTER 1}

\section{INTRODUCTION}

Construction sector is one of the most risky industries regarding internal fraud due to its complex and costly nature and dense third-party contracting relationships. This very nature of construction business creates suitable circumstances for things to go wrong. Organizations lose up to 7 percent of their annual revenue to fraud according to the Association of Certified Fraud Examiners. In addition to monetary loss, internal fraud may also cause reputation loss, business disruption and regulatory sanctions.

Construction contractors should identify where risks of fraudulent acts and corrupt practices may exist and then implement controls to mitigate those risks. However, growing complexity of construction business, high employee turnover ratios in the sector, low frequency of construction projects, insufficient regulations and understaffing due to cost deduction strategies, make difficult to develop control mechanisms. Moreover, management supervision and control over operations are very low on the operations since the operations are performed at a remote site, mostly far away from the company headquarters. Prevention of internal fraud should not be the only reason for contractors to think about adopting audit mechanism and control processes as efficient control structures streamline operations, reduce waste time and material, and support accounting functions.

In this study, it is aimed to develop an understanding about internal fraud and corruption problem in construction industry. The study consists of explanation of common fraud types experienced in construction industry and respective 
prevention methods. Moreover, in the study, the results of fraud awareness survey applied to Turkish construction contractors are also shared. 


\section{CHAPTER 2}

\section{LITERATURE REVIEW}

Literature review is performed on the subject of corruption and internal fraud in construction industry. While reviewing the literature, mostly international references are used. However, where available the information related to Turkey is also introduced. The aim of this review is to understand the magnitude of the corruption problem, to present governmental and non-governmental precautions against corruption and internal fraud, and to demonstrate the results of selected international surveys on corruption and internal fraud carried by independent firms.

\subsection{Corruption Issue}

\subsubsection{Corruption Issue in Construction Industry}

Transparency International's ${ }^{1}$ (TI) Bribe Payers Index ${ }^{2}$ of 2008 stated that public works contracts and construction was the most corrupt sector (Riaño, J. and Hodess, R., 2008). It was followed by real estate and property development sector and oil and gas sector. Krishnan (2009) mentioned that it was not a surprising fact that the construction sector was the most corrupt sector due to its complex nature of doing business and involvement of so many different parties. There are also some characteristics of construction sector that also make construction business

\footnotetext{
${ }^{1}$ Transparency International is a global civil society organization trying to fight with corruption.

${ }^{2}$ Bribe Payers Index is a ranking of the world's most economically influential countries according to likelihood of the companies of these countries to bribe abroad. Transparency International carried out similar surveys in the years 1999, 2002 and 2006.
} 
more complicated compared to the other sectors, such as large flow of public money, highly competitive nature of tendering process, lack of transparent selection criteria for projects, political interference, monopolistic nature of service delivery, tight margins, and close relationships between contractors (Sohail and Cavill (2008), Stansbury (2005), Rodriguez et al. (2005)). These specific properties and specific conditions of the construction sector increase the tendency of corruption.

\subsubsection{Magnitude, Results and Future of The Corruption Problem in Construction Sector}

Jong et al. (2009) indicated that the actual cost of corruption was unknown; however, estimated loss was around USD 500B per year which was almost $10 \%$ of the construction economy. When the loss due to corruption is compared against the government budgets, it is obvious that this issue needs to be analyzed in detail.

Krishnan (2009) mentioned non-monetary results of corruption in construction sector and gave some examples to non-monetary losses such as loss of lives due to corruptly constructed buildings, loss of natural resources due to unnecessary projects and environmental damages due to constructions that do not comply with the related rules and the regulations. Most the time, the indirect results of corruption are not considered thoroughly due to their imponderable nature. However, countries like Turkey, which has seismically active strike-slip fault zones, should give enough importance to the corruption issue in order to prevent unfavorable indirect consequences.

Henry (2009) stated that it was forecasted that in $2015,80 \%$ of the money spent on infrastructure projects would be spent in developing countries and according to United Nations (UN), in 2020 most of the major cities would be located in those developing countries. According to Henry (2009) emerging trends might raise potential corrupt actions especially in these developing countries; because in 
developing countries there would not be enough resources to meet the demand for construction projects. Thus, global consortiums (joint ventures) will be formed in order to support engineering, procurement and construction works in developing countries and these newly established firms and consortiums will create their own way of doing business, which will create lots of uncertainties. As a result, these uncertainties would create a great potential for corrupt practices.

In conclusion, corruption is a major problem for construction sector in the current situation due to both the monetary and non-monetary results. Moreover, it seems that corruption will keep being an important issue in the coming years due to the above-mentioned possible growth scenarios.

\subsection{Parties in Corruption and Potentially Corrupted Acts}

Corruption is a form of agreement between two parties who agree to act in a corrupted manner. For the construction/engineering businesses, Jong et al. (2009) categorized the parties that may take part in corrupted act. These potential parties were government officials, owners of the companies, responsible technical staff, material and equipment suppliers, investors, lenders and regulatory/permitting agencies.

According to Jong et al. (2009) and, Sohail and Cavill (2008), the types of corrupted acts are listed below:

- Kickback and bribery,

- Embezzlement,

- Front companies,

- Bid rigging and collusion,

- Fraud,

- Conflicts of interests. 


\subsection{Precautions Against Corruption}

\subsubsection{Methods For Preventing Corruption}

Transparency and accountability are two important subjects that should be considered while doing business in the construction sector.

Jong et al. (2009) recommended creating more open and transparent decision making processes from procurement phase till completion. These transparent processes should be performed by all parties involved in the construction project. Moreover, transparency point of view should be adopted by the owners of the project (governmental or private), regulators, engineers, contractors, subcontractors, material and equipment suppliers, founders and lenders.

Besides, Sohail and Cavill (2008) mentioned the importance of accountability and listed the benefits of greater accountability while combating with corruption:

- Forces service providers to explain their actions,

- Reduces the corruption incidences with the help of reducing the bureaucratic procedures and clearly identifying the responsibilities,

- Changes the tolerance level of citizens to poor quality services; therefore, demand for high quality services increases,

- Creates punishments for the ones who behaved immorally or performed ineffectively.

As a result, in order to develop a transparent and open business structure in construction sector governments, organizations and construction companies should constitute legislations, anti-corruption programs and specific codes of business conducts. 


\subsubsection{International Conventions}

Countries have been trying to develop legislations to improve existing anti corruption precautions. Besides, multinational organizations are also trying to make countries develop anti-corruption programs, laws, etc. There are some important multinational conventions which were announced by organizations in order to reinforce the fight against corruption and bribery. The following list shows some of the most important conventions:

- United Nations Convention against Corruption,

- Organization for Economic Cooperation and Development (OECD) Convention on Combating Bribery of Foreign Public Officials in International Business Transactions,

- Inter-American Convention against Bribery,

- Council of Europe Conventions against Corruption,

- European Union Conventions against Bribery and Corruption,

- African Union Convention on Preventing and Combating Corruption,

- OECD / Asian Development Bank Anti Corruption Action Plan for the Asia and the Pacific.

United Nations Convention against Corruption (2003) is the most noteworthy one as it covered all of the 140 member countries. The convention requests the following items from the member countries:

- Development of anti corruption policies,

- Establishment of transparent public processes,

- Criminalization of the acts both in public and private sector such as money laundering, bribery, influencing authorities, abuse of power and expanding the notion of liability of legal persons,

- Establishment of an independent anti-corruption agency, 
- Development of cooperation on international and national levels.

OECD Anti-Bribery Convention (2000) was the first international anti-corruption instrument which established compulsory standards for member countries in order to accuse bribery of foreign public officials in international business transactions.

In 2005, G8 countries demonstrated their support to OECD Anti-Bribery Convention by stating the phrase "Reduce bribery by the private sector by rigorously enforcing laws against the bribery of foreign public officials, including prosecuting those engaged in bribery; strengthening anti-bribery requirements for those applying for export credits and credit guarantees, and continuing our support for peer review, in line with the OECD Convention; encouraging companies to adopt anti-bribery compliance programs and report solicitations of bribery; and by committing to co-operate with African governments to ensure the prosecution of those engaged in bribery and bribe solicitation." in Glenagles Communiqué.

Some countries developed specific local regulations in order to prevent corruption and bribery. Foreign Corruption Practice Act (1977) developed by US government is one of the leading practices. This act prohibits bribing foreign government officials by US companies or their subsidiaries.

National Code of Practice, which is another example for preventing corruption, was adopted for construction sector by Federal and State governments of Australia in 1997. The code defined the rules for almost all parties which have roles in construction business. Moreover, according to the code; all the parties in construction business have to obey the rules defined by the code in order participate in governmental projects. Hartley (2009) summarized the main rules that need to be fulfilled by all parties in Australia: 
- "Business relationships and contracts must reflect trust, cooperation, equity, honesty, and high standards of behavior”,

- "Principles of ethical behavior must be adhered to at all times and at all levels",

- "Bidding processes must be honest and fair",

- "Anticompetitive behavior or any other practice which denies participants legitimate business opportunities are unacceptable”.

Hartley (2009) mentioned that not being in compliance with the rules have some consequences varying from verbal warning up to disqualification from tenders depending on the level of wrongdoing.

\subsubsection{Precautions Developed By Federations, Institutions and Organizations}

\subsubsection{International Federation of Consulting Engineers}

International Federation of Consulting Engineers (FIDIC) ${ }^{3}$ developed Business Integrity Management System (BIMS) ${ }^{4}$ which is an internal system within the firm to prevent corrupt behavior and to encourage integrity. According to Jong et al. (2009), this system helps the construction sector while fighting with corruption as the system tries to constitute uniform, transparent and accountable practices.

Code of ethics developed by FIDIC is also an important preventive measure of corruption. According to the code; consulting engineer should not offer or accept any kind of remuneration which seeks to influence selection process or seeks to affect the fairness of the engineer. Moreover, consulting engineer should be totally open to any legitimately constituted investigative body.

\footnotetext{
${ }^{3}$ FIDIC is the International Federation of Consulting Engineers representing globally the consulting engineering industry.

${ }^{4}$ BIMS was developed by Engeli and Pieth in 2000 on behalf of FIDIC.
} 


\subsubsection{World Economic Forum}

World Economic Forum (WEF) ${ }^{5}$ Partnering against Corruption Initiative (PACI) was formally initiated by CEOs from different industries to develop anticorruption procedures. The initiative issued PACI Principles for engineering and construction sector in 2004 in order to provide a framework for good business practices and risk management strategies for countering bribery.

\subsubsection{The World Federation of Engineering Organizations}

The World Federation of Engineering Organizations (WFEO) ${ }^{6}$ established the Anti-Corruption Standing Committee to constitute a single tone for engineers about anti-corruption.

\subsubsection{Global Infrastructure Anti Corruption Centre}

Global Infrastructure Anti Corruption Centre (GIACC) ${ }^{7}$ provides anti-corruption services such as planning and implementation of anti-corruption measures, assessment and certification of anti corruption measures, anti corruption compliance monitoring, anti corruption training and anti corruption advice.

\subsubsection{Civil Engineering Institutions and Associations}

American Society of Civil Engineers (ASCE) and The United Kingdom

\footnotetext{
${ }^{5}$ WEF is an independent international organization committed to improving the state of the world by engaging business, political, academic and other leaders of society to shape global, regional and industry agendas (www.weforum.org)

6 WFEO is an international, non-governmental organization representing the engineering profession worldwide and in existing structure it is representing more than $18 \mathrm{M}$ engineers (www.wfeo.net)

${ }^{7}$ GIACC is an independent nonprofit organization provides resources and services for the purpose of preventing corruption in the infrastructure, construction and engineering sectors (www.giaccentre.org)
} 
Institution of Civil Engineers have published several codes of business conducts and ethical conducts in order to develop anti-corruption procedures and to inform engineers about best ethical practices.

\subsubsection{International Federation of Accountants}

In 2002, the International Auditing and Assurance Standards Board of the International Federation of Accountants (IFAC) ${ }^{8}$ issued International Standards on Auditing (ISA) ${ }^{9}$ No:240: The Auditors' Responsibility to Consider Fraud in an Audit of Financial Statements. Those standards define expected fraud considerations from auditors.

\subsection{Corruption Problem in Turkey}

TI consolidates different sources of information and publishes Corruption Perceptions Index (CPI) to exhibit perceived level of corruption in different countries. According to the current index that was launched on 26 October 2010, Turkey had a score of 4.4 (10 for highly clean and 1 for highly corrupt) and ranked as $56^{\text {th }}$ least corrupt country among 178 countries.

According to the index, Turkey, like other developing countries, maintains corruption risk. Melgar et al. (2009) emphasized the devastating results of high level of perceived corruption and stated that high level of perceived corruption may generate a "culture of distrust". Moreover, if the level of perceived corruption increases, people may start to see some corruptive actions as usual such as giving and taking gifts seeking to affect decisions of others.

\footnotetext{
${ }^{8}$ IFAC is an independent standard-setting board. IFAC develops international standards on ethics, auditing and assurance, education and public sector accounting.

${ }^{9}$ International Standard on Auditing defines the standards for financial audit.
} 


\subsubsection{Turkey`s Legal Status Against Corruption}

There are some local laws, regulations and decrees against corruption in Turkey. These statements were listed below:

- New Turkish Penal Code,

- Public Procurement Act,

- The Act on Prevention of Money Laundering,

- The Act on Civil Servants,

- The Act on Declaration of Properties, Combating Bribery and Corruption,

- The Act on the Right to Access to Information,

- The Act on Combating Organizations Pursuing Illicit Gain.

The most important local law against corruption is the Law No: 5237, article 252 in Turkish Penal Code which has been issued in order to penalize domestic bribery acts.

Most of the existing anti-corruption laws and other related legislations have evolved in the last decade, mostly due to the effect of conventions mentioned in Chapter 2.5. Below list shows some milestones in Turkey's legal history against corruption (Republic of Turkey Ministry of Finance Financial Crimes Investigation Board, 2008).

- April 1990: Ratification of Law No 3628; concerning the declaration of assets and combating bribery and corruption,

- February 2000: Ratification of Law No 4518; acceptance of the OECD Convention on combating bribery of foreign public officials in international business transactions,

- March, 2001: Acceptance of a Judgment on the acquis communautaire on undertaking a National Programme of Coordination and Observation. This 
step showed that anti-corruptive actions were prioritized by government,

- May 2001: Formation of a working committee for effective management and fight against corruption,

- January 2002: Acceptance of the action plan of increasing transparency in Turkey and developing effective management in the public sector by Cabinet Members,

- November 2002: Explanation of the Priority Action Plan of fighting against corruption by $58^{\text {th }}$ Cabinet Members,

- January 2003: Ratification of Law No 4782; Amending Certain Laws for the Prevention of Bribing Foreign Public Officials in International Commercial Transactions according to OECD's Anti Bribery Convention which has been ratified by all of the OECD countries including Turkey,

- April 2003: Ratification of Law No 4852, Special Law of the European Council against corruption,

- December 2003: Signing the United Nations Agreement against Corruption,

- June 2005: Ratification of the amendments in Law No 4782 and establishment of Law No 5377 which stipulates bribery of foreign public officials,

- January 2004: Ratification of Law No 5065; Endorsement of the European Council Criminal Law related to corruption,

- August 2006: Ratification of Law No 5506; acceptance of "United Nations Fight against Corruption Agreement" by Cabinet Members,

- February 2009: Amendment of Labor Law 4857, in order to strengthen measures to protect whistleblowers in the private sector from retaliation and retribution.

OECD's Anti Bribery Convention is an important milestone for cross border business deals of Turkish construction contractors, because subsequent to this convention Turkey established the laws numbered 4782 and 5377 against 
international bribery. These laws are the first global instruments in Turkish Penal Code to fight corruption in cross-border business deals. The law numbered 5377 is focused on bribery of foreign public officials and imposing criminal penalties on those who give offer or promise any bribes to foreign public officials. These potential wrongdoings are followed by Financial Crimes Investigation Board (MASAK) which is formerly established to combat with money laundering. However, in the current structure it is also responsible for fighting with international bribery.

Turkish construction companies should give high attention to this international anti-bribery law due to their huge overseas business volume. According to the publication of Turkish Contractors Association (2009), Turkish contractors performed almost 5000 projects in 70 different countries and total volume of business was almost USD 130B between the years 1972 and 2008. Moreover, in 2008 total monetary value of new international construction projects was USD 23B.

Above mentioned conventions and declarations revealed the urgency of adopting anti-corruption precautions by Turkish construction companies, because these companies not only have a huge business volume both in the local and international market, but also have continuous relationships with local and international governmental entities.

\subsection{International Surveys Related to Internal Fraud and Corruption}

Some surveys are reviewed in order to draw the statistical picture of the effects of internal fraud and corruption on the construction sector. Moreover, the results of these surveys which may affect the construction sector are also discussed. 


\subsubsection{Report to The Nations on Occupational Fraud and Abuse Performed By Association of Certified Fraud Examiners}

Association of Certified Fraud Examiners (ACFE) ${ }^{10}$ publishes Report to Nations on Occupational Fraud and Abuse to analyze eventuated internal fraud cases. The latest report was published in 2010 by using the information about 1843 different occupational fraud cases observed by Certified Fraud Examiners ${ }^{11}$ (CFE) from different countries.

When overall picture of the fraud cases are reviewed, it is observed that internal fraud cases caused considerable losses. In $32.4 \%$ of the cases, average loss amount is more than USD 0.5M. Besides, the median of the loss amount caused by all internal fraud cases is around USD 160K. Moreover, it was observed that the loss amount exceeded the USD $1 \mathrm{~K}$ level in $75 \%$ of the cases.

In the report, it was indicated that three main types of occupational fraud attempted by fraudsters are asset misappropriation, corruption and financial statement fraud.

According to the survey, asset misappropriation (stealing or misusing the organization's resources) is the most frequent but least costly type of occupational fraud. Almost $86 \%$ of the fraud cases were asset misappropriation and median of loss amount related to asset misappropriation was USD 135K.

One other common type of occupational fraud type was corruption which is defined as scheme involving the usage of personal influence in business transactions in order to obtain a personal benefit. According to the survey, almost one-third of the cases involved corruption and median of the loss amount was

\footnotetext{
${ }^{10}$ ACFE is the World's largest anti fraud organization.

${ }^{11} \mathrm{CFE}$ is a designation awarded by the Association of Certified Fraud Examiners.
} 
USD 250K.

The last type of fraud is financial statement fraud, which involves misstating the organizations' financial information to obtain illegal benefit, was the least frequent but most costly type of occupational fraud. Financial statement fraud occurred in almost $5 \%$ of the cases; however, they caused almost USD 4,100K median loss.

\subsubsection{Ernst and Young's $11^{\text {th }}$ Global Fraud Survey}

Ernst and Young's ${ }^{12}$ (EY) $11^{\text {th }}$ Global Fraud Survey was conducted between 2009 and 2010 including 1,409 interviews in 36 countries. David Stulb, Global Leader of Fraud Investigation and Dispute Services of EY, stated that most of the interviewees were selected from CFOs, internal audit heads, legal heads and compliance heads in order to identify different risks associated with fraud.

According to the results of the survey, Turkish companies are under the risk of being subject to internal fraud. $18 \%$ of the respondents from the Middle East and Africa Region, where Turkey is included, experienced a significant internal fraud case in the last two years.

$75 \%$ of the survey respondents mentioned that their companies have carried out at least one fraud risk assessment. However, $60 \%$ of the remaining population of the respondents stated that their companies have never carried out a fraud risk assessment and $40 \%$ of the remaining population accepted that they did not know what the fraud risk assessment process is.

The survey showed that $30 \%$ of the CFOs in the region including Turkey strongly agree that board of directors should understand the business thoroughly in order to

\footnotetext{
${ }^{12} \mathrm{EY}$ is one of the largest professional services firms in the world and one of the Big Four auditors (along with PricewaterhouseCoopers, Deloitte and KPMG).
} 
be an effective safeguard against fraud, bribery and corruption. Boards of directors' previous demands from CFOs were used to assess the board of directors' ability to prevent corruption and internal fraud. According to the results, $47 \%$ of CFOs in the region including Turkey were assigned to review existing anti-fraud and corruption controls, $38 \%$ of the CFOs were assigned to assess the fraud risks and only $24 \%$ of the CFOs were assigned to establish whistleblower hotlines by board of directors.

Compliance issues were another main topic within the survey. Most significant compliance issues are listed in the below table.

Table 1: Most significant compliance issues

\begin{tabular}{|l|c|}
\hline Compliance issue & $\begin{array}{r}\text { \% of total } \\
\text { number of } \\
\text { respondents }\end{array}$ \\
\hline Data security & 45 \\
\hline Unethical business conduct & 37 \\
\hline Competition law & 31 \\
\hline Health and safety & 28 \\
\hline Environmental & 27 \\
\hline Labor & 24 \\
\hline
\end{tabular}

It is observed that most of the compliance issues rose by the respondents should be considered by construction companies as they affect construction business directly.

Respondents also identified the most effective ways to prevent corruption and internal fraud. Internal controls, audits and trainings are identified as the most effective ways to mitigate corruption and internal fraud risk. Below table shows 
the list of effective prevention methods.

Table 2: Most effective fraud prevention methods

\begin{tabular}{|l|c|}
\hline Prevention method & $\begin{array}{c}\text { \% of total } \\
\text { number of } \\
\text { respondents }\end{array}$ \\
\hline Internal control & 74 \\
\hline Internal audit & 65 \\
\hline Management reviews & 53 \\
\hline Internal education and anti fraud policy & 51 \\
\hline External audit & 45 \\
\hline Whistle-blowing & 42 \\
\hline Regular rotation of personnel & 31 \\
\hline
\end{tabular}

If a fraud case occurs, it is very important to detect it as soon as possible. Respondents selected the best mechanisms to detect frauds sooner. Below table depicts these.

Table 3: Best mechanisms to detect frauds sooner

\begin{tabular}{|l|c|}
\hline Prevention method & $\begin{array}{r}\text { \% of total } \\
\text { number of } \\
\text { respondents }\end{array}$ \\
\hline Stronger internal audit & 71 \\
\hline More robust segregation of duties & 59 \\
\hline Stronger compliance & 52 \\
\hline Additional board/audit committee oversight & 40 \\
\hline Stronger legal function & 30 \\
\hline
\end{tabular}




\subsubsection{EY's European Fraud Survey, 2009}

European Fraud Survey (2009) is another survey conducted by Ernst and Young. This survey was performed in January and February 2009 with the participation of 2,246 employees from 22 countries. In European Fraud Survey of EY, David Stulb indicated that the survey was aimed to measure perception of fraud risk, to understand the respondents' ways of thinking in relation to fraudulent acts under some circumstances like financial crisis and to reveal managements' perceived depth of commitment to fraud risk mitigation.

$55 \%$ of the respondents expected an increase in the corporate fraud cases for the coming years, whereas the expectation percentage of the respondents from Turkey was $67 \%$. This high expectation level showed the importance of the fraud risk in Turkey.

The respondents were anticipating greater fraud risk because of distrust to the management of the companies that they are working for. $39 \%$ of them stated that the managements did not focus on anti-fraud practices and $33 \%$ of them mentioned directly that they did not trust to the management.

Despite the increased fraud risk, the survey indicated that $44 \%$ of the respondents said that the efforts of the companies to combat fraud were increased. Similarly, $46 \%$ of the respondents from Turkey also mentioned that their companies had increased efforts against fraud.

On the other hand, $16 \%$ of the respondents did not believe that their company was under increased risk of fraud, $57 \%$ believed that their processes and procedures were adequate, $45 \%$ of such individuals believed that the risk areas were sufficiently covered and $40 \%$ of them believe that their companies have strong culture of integrity/honesty. 
Information on companies' methods to prevent fraud is also an important outcome obtained from EY's survey. Common fraud prevention methods of the companies are listed below:

Table 4: Fraud prevention methods used by the companies

\begin{tabular}{|l|c|}
\hline Anti-fraud measure & $\begin{array}{r}\text { \% of total } \\
\text { number of } \\
\text { respondents }\end{array}$ \\
\hline Internal auditing & 68 \\
\hline External auditing & 54 \\
\hline Stronger controls/scrutiny of expenditures & 51 \\
\hline Code of conduct & 49 \\
\hline Human Resources/Legal counsel & 38 \\
\hline Legal due diligence & 28 \\
\hline Anti-fraud training & 24 \\
\hline Person with a position of confidentiality & 24 \\
\hline Whistle-blowing hotline & 21 \\
\hline Web-based hotline & 12 \\
\hline
\end{tabular}

Survey also questioned the tolerance level towards unethical behavior during economic crisis. Some respondents admitted that they may make payments to employers or may manipulate financial statements in order to sustain their business. Below table shows the acts which were stated acceptable during an economical crisis. 
Table 5: Justifiable actions in order to survive business

\begin{tabular}{|l|c|c|}
\hline Type of action & $\begin{array}{c}\text { \% of total } \\
\text { number of } \\
\text { respondents }\end{array}$ & $\begin{array}{r}\text { \% of total } \\
\text { number of } \\
\text { respondents } \\
\text { from Turkey }\end{array}$ \\
\hline Cash payments to win/retain business & 25 & 53 \\
\hline Personal presents to win/retain business & 24 & 49 \\
\hline Entertainment to win/retain business & 19 & 32 \\
\hline Misstating company's financial performance & 8 & 10 \\
\hline None of the above & 41 & 18 \\
\hline
\end{tabular}

It is observed that respondents from Turkey were more likely to justify improper acts during an economic crisis according to overall respondents.

\subsubsection{Pricewaterhousecoopers`s Engineering and Construction Part of Global Economic Crime Survey, 2010}

Pricewaterhousecoopers's ${ }^{13}$ (PWC) Engineering and Construction part of Global Economic Crime Survey (2010) was conducted across 43 countries with the participation of 226 respondents. These responses were collected between July 2009 and March 2010.

One of the main outcomes of the survey was the types of economical crimes occurred in the engineering and construction sector. The most frequent ones were:

- Asset misappropriation (64\%),

- Bribery and corruption (47\%),

- Accounting fraud (38\%).

${ }^{13}$ PWC is one of the largest professional services firms in the world and one of the Big Four
auditors (along with EY, Deloitte and KPMG). 
Second main outcome was the identification of the factors which increase the incentives/pressures to commit fraud. Almost half of the respondents stated that internal fraud would occur under hardly achievable financial targets. $40 \%$ of them mentioned that fear of losing their jobs was also another resource which would cause pressure to commit fraud.

Another main outcome was the collateral damage caused by fraudulent activity. The survey results showed that internal fraud cases affected morale of the employees, damage the business relationships and reputation of the company.

The last outcome was the profile of internal fraudster. In Engineering and Construction sector, in $45 \%$ of the cases, fraudster is a member of Middle Management; in $34 \%$ of the cases, is a member of junior staff and in $21 \%$ of the cases is a member of senior executives.

\subsubsection{Kroll's Global Fraud Survey}

Kroll $^{14}$ commissioned Economist Intelligence Unit ${ }^{15}$ to carry out Global Fraud Survey for 2010. More than 800 senior executives participated to the survey and it was conducted between July and August 2010.

Survey results revealed the importance of the fraud problem for construction sector. The results showed that almost $84 \%$ of the surveyors had been affected by fraud.

According to the survey, the most common types of internal fraud in construction sector were:

\footnotetext{
${ }^{14}$ Kroll is one of the world's leading risk consulting companies.

${ }^{15}$ The Economist Intelligence Unit is an independent source for economic and business research, forecasting and analysis
} 
Table 6: Types of internal fraud in construction sector

\begin{tabular}{|l|c|}
\hline Type of internal fraud & $\begin{array}{r}\text { \% of total } \\
\text { number of } \\
\text { respondents }\end{array}$ \\
\hline Management conflict of interest & 28 \\
\hline Theft of physical assets or stock & 26 \\
\hline Information theft, loss or attack & 21 \\
\hline Corruption and bribery & 18 \\
\hline Vendor, supplier or procurement fraud & 16 \\
\hline
\end{tabular}

The survey demonstrated the main areas that companies invested on in order to prevent internal fraud. Below table shows those areas:

Table 7: Areas those companies invest in order to prevent fraud

\begin{tabular}{|l|c|}
\hline Prevention area & $\begin{array}{c}\text { \% of total number of } \\
\text { respondents }\end{array}$ \\
\hline Financial controls & 65 \\
\hline Staff training & 61 \\
\hline IT security & 60 \\
\hline Management controls & 56 \\
\hline Physical asset security & 56 \\
\hline Reputation monitoring & 54 \\
\hline Due diligence & 53 \\
\hline IP and trademark monitoring program & 53 \\
\hline Risk management systems & 51 \\
\hline
\end{tabular}




\subsubsection{KPMG's Global Construction Survey, 2010}

KPMG's $^{16}$ Global Construction Survey was conducted in 2010 with the participation of 140 engineering and construction companies around the world.

According to the survey, $46 \%$ of the contractors stated that they did not have appropriate anti-corruption procedures and policies.

\subsubsection{KPMG's Global Construction Survey, 2005}

KPMG's Global Construction Survey was conducted in the first half of 2005 with the participation of 25 leading organizations, which were selected from top 50 global construction companies announced by the Engineering News Record.

According to the survey, $29 \%$ of the construction companies faced with an internal fraud case. The fraud cases ranged from low impact ones to most serious ones such as procurement fraud, fraudulent internal reporting and embezzlement.

Last outcome was that $8 \%$ of construction companies were not confident in detecting and preventing fraud.

\footnotetext{
${ }^{16} \mathrm{KPMG}$ is one of the largest professional services firms in the world and one of the Big Four auditors (along with EY, Deloitte and PWC)
} 


\section{CHAPTER 3}

\section{INTERNAL FRAUD AND CORRUPTION}

In this chapter the following subjects will be discussed:

- Definition of fraud,

- Definition of corruption,

- The differences between fraud and corruption,

- The main reasons for perpetrating fraud,

- The profile of the fraudster,

- Most common fraud types,

- Most common fraud prevention methods.

\subsection{The Definition and Description of Fraud}

According to Oxford Dictionary, the meaning of fraud is "false representation by means of a statement or conduct, in order to gain a material advantage”. This wrongdoing not only provides material advantage to fraudster but also causes loss to the victim party. Fraud Examiners Manual ${ }^{17}$ of ACFE (2008) defined fraud in a broader sense by saying "fraud encompasses a range of irregularities and illegal acts characterized by intentional deception or misrepresentation, which an individual knows to be false or does not believe to be true”. Both definitions emphasize three important points while defining fraud:

- Misrepresentation of facts or avoiding obligations,

17 Fraud Examiners Manual, published by ACFE, is the global standards for the anti-fraud profession. 
- Causing loss to another party,

- Gaining illegal or unethical financial advantage.

\subsection{Definition of Corruption}

In Oxford Reference Dictionary, corruption is explained as "The use of bribery to influence the actions of a public official. More generally, corruption refers to obtaining private gains from public office through bribes, extortion, and embezzlement of public funds". The definition of Oxford Reference Dictionary mainly emphasizes the actions against public officials. However, The Chartered Institute of Public Finance and Accountancy of UK defined corruption in a broader sense by stating that corruption is offering, giving, soliciting or accepting of an inducement or reward, which may influence the action of any person contrary to the proper conduct of his/her duties by providing direct benefit to him/her or to anyone close to him/her. In conclusion, corruption is an act which is perpetrated by individuals that work for public or private sectors, want to enrich themselves and/or the ones close to them by misusing the authority assigned to them.

\subsection{Main Differences between Fraud and Corruption}

There are some conceptual differences between internal fraud and corruption. According to Asian Organization of Supreme Audit Institutions (ASOSAI) ${ }^{18}$ these differences are related to:

- Parties included in the scheme,

- Scheme method,

- Intentions of perpetrator,

- Results of wrongdoing.

18 ASOSAI is one of the regional groups of the international organization of supreme audit institutions. 
Below table illustrates the differences between internal fraud and corruption:

Table 8: Main conceptual differences between fraud and corruption

\begin{tabular}{|c|c|c|}
\hline & Fraud & Corruption \\
\hline $\begin{array}{l}\text { Parties } \\
\text { included }\end{array}$ & $\begin{array}{l}\text { There are two parties included in } \\
\text { a Fraud Scheme: } \\
\text { - Fraudster } \\
\text { - Victim }\end{array}$ & $\begin{array}{l}\text { There are at least two parties: } \\
\text { - Person/people who offers bribe } \\
\text { - Party/parties accepting the bribe }\end{array}$ \\
\hline Scheme & $\begin{array}{l}\text { Deliberate omission of } \\
\text { responsibility or } \\
\text { misrepresentation of some facts }\end{array}$ & Misuse of an authority \\
\hline $\begin{array}{l}\text { Intentions of } \\
\text { included } \\
\text { parties }\end{array}$ & $\begin{array}{l}\text { Providing personal benefit by } \\
\text { affecting the victim negatively }\end{array}$ & $\begin{array}{l}\text { Providing personal benefit by providing } \\
\text { illegal rights to briber }\end{array}$ \\
\hline $\begin{array}{l}\text { Results of } \\
\text { wrongdoing }\end{array}$ & $\begin{array}{l}\text { Results with the loss of victim } \\
\text { and illegal gain of fraudster }\end{array}$ & $\begin{array}{l}\text { Misuse of authority does not always cause } \\
\text { loss to the organization that provided the } \\
\text { authorization to the corrupted officer }\end{array}$ \\
\hline
\end{tabular}

In conclusion, in fraud and corruption schemes, corrupted individuals do not consider negative consequences of their actions, only aim to obtain illegal benefit by their unfavorable actions.

\subsection{Why People Commit Fraud}

Cressey (1953) (as cited in Lou and Wang, 2009), an expert on the sociology of crime, interviewed with fraudsters in the Illinois State Penitentiary at Joliet, USA, in order to understand the factors that lead individuals to trust violation. His study revealed three main reasons that drive people to fraudulent acts. These reasons are non-shareable financial pressure, certain opportunities to violate trust and justification of the improper situations. 
The reasons that drive people to perpetrate fraud were adopted by the Auditing Standards Board of the American Institute of Certified Public Accountants under Statement on Auditing Standards (SAS) No: 99: Consideration of Fraud in a Financial Statement Audit ${ }^{19}$ and embodied within the fraud triangle theory. According to the theory the reasons for perpetrating fraud are financial pressure, rationalization and opportunity.

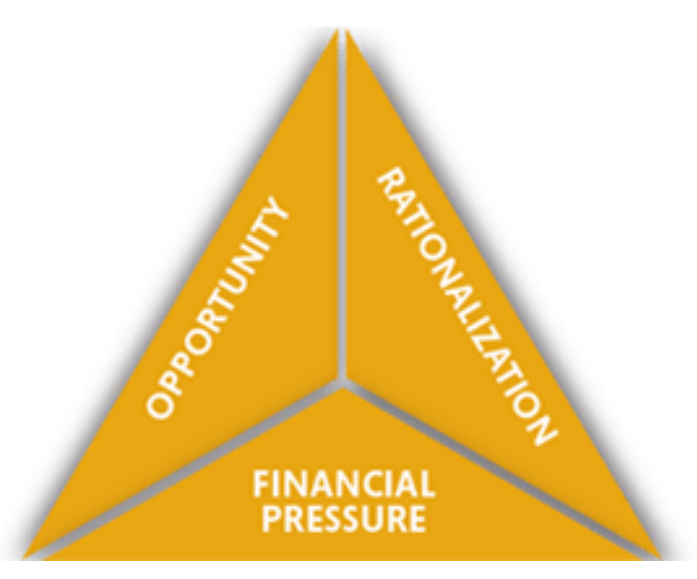

Figure 1: Fraud triangle

The components of fraud triangle occur in each and every fraud case if any of the abovementioned components do not exist, the fraud risk decreases considerably.

The components of fraud triangle are discussed in following parts.

\subsubsection{Financial Pressure}

Perceived financial pressure is one of the three elements that picture the fraud triangle theory. According to the fraud triangle theory one may commit fraud, if

\footnotetext{
19 SAS 99 is an auditing statement issued by the Auditing Standards Board of the American Institute of Certified Public Accountants
} 
he/she perceives non-shareable financial pressure and believes that the only solution is the violation of the individuals' financial trust. In other words, potential fraudster has a driving need for additional income for various purposes and believes that he/she would be unable to compensate these costs with his/her legitimate income.

These driving needs may occur due to living beyond legitimate means and cost of living such as expensive meals, clothing, jewelry, international trips, unexpected medical expenses, accumulated credit card debt, high tuition expenses of children, etc. Besides, illicit activities such as drug addiction, gambling, extramarital relationships, etc., may also lead to the financial pressure.

In conclusion, anyone may attempt a fraudulent act due to unexpected changes in needs or trying to keep up an irrecoverable life style.

\subsubsection{Rationalization (Justification)}

Another component of fraud triangle is rationalization. Fraudster tries to find a way to justify his/her improper acts. Cendrowski et al. (2007) stated that there are three types of perceptions. First one is not admitting the wrongdoing as a crime, second one is believing that the idea that he/she deserves more and the last one is feeling revenge against the company. There are some anonymous statements of fraudsters to rationalize their wrongdoing such as:

- Everyone else was doing it,

- The company could afford it,

- I needed the money,

- It was just a loan... I would have repaid it,

- I felt used and wanted revenge,

- I meant no harm and did no harm, 
- I did it to keep the business afloat,

- Bribery is the norm in this type of business,

- What I did was entirely appropriate for someone in my position.

Cendrowski et al. (2007) also mentioned that usually fraudsters begin with smaller amounts because it is easier to justify smaller amounts. However, sense of magnitude changes and greater amounts start to be seen small by the fraudster.

\subsubsection{Opportunity}

Fraudster sometimes discovers weaknesses in control processes/procedures and turns these weaknesses into opportunities to commit fraud. Below list shows some critical weaknesses in control processes/procedures:

- Ineffective monitoring of management,

- Ineffective accounting system,

- Ineffective information technologies systems.

These weaknesses typically rise from poorly designed control processes/procedures such as poor application of segregation of duties principle and poor enforcement of controls.

\subsection{Fraudster's Profile}

According to Fraud Examiners Manual of ACFE (2008), fraudster is a person who "knows that it could result in some unauthorized benefit to him or her, to organization, or to another person, and can be perpetrated by persons outside and inside the organization".

In 1939, Seidman identified the potential fraudster as “... generally a man-though 
fraud is by no means exclusively a masculine machination-about thirty-six, married, has children, owns a car, participates in social and communal work, and is of wholesome convivial habits. He has been in the company's employ over five years and, ironically enough, has advanced to a position of trust by honest endeavor and commendable merit. The de-faulter lives anywhere and occupies any position, from watchman to president."

The cases held in Association of Certified Fraud Examiners' Report to the Nations on Occupational fraud and Abuse (2010) revealed the personal characteristics of a fraudster:

- An employee or manager ( $42 \%$ and $41 \%$ of the cases respectively),

- Male; (67\% of the cases, in Europe $82 \%$ of the cases),

- Between the ages of 31 and 45 (55\% of the cases),

- Has five years of experience in victim organization (46\% of the cases),

- Has a graduate or post graduate degree (52\% of the cases),

- Is a member of;

- Accounting department (22\% of the cases),

- Operations department (18\% of the cases),

- Sales department (14\% of the cases),

- Executive/upper management (14\% of the cases),

- Customer services ( $7 \%$ of the cases),

- Purchasing department (6\% of the cases).

- Does not have a criminal background ( $86 \%$ of the cases),

- Previous employment contracts were not terminated ( $82 \%$ of the cases).

In conclusion, fraud perpetrator is mostly a manager or an employee, is a male, is between the ages of 31 and 45, has one to five years of experience in the organization, has a graduate or post graduate degree and has never been convicted or charged with a crime before. Moreover, he is likely to work for one of the 
following departments; accounting, operations, sales, executive/upper management, customer services or purchasing.

\subsection{Internal and External Indicators of Fraud Risks}

There are some internal and external circumstances that may indicate existence of fraud in the company. Internal indicators are related to the company control structure and behaviors of employees. External indicators are related to the market characteristics in which the company operates. Both of these indicators are also called as "Red Flags".

\subsubsection{Internal Indicators of Fraud Risks - Company Structure}

Characteristics of procedures/processes applied in the company and/or the ethical culture of the company may indicate an existence of fraud risks.

Organization structure, delegation of authorities and ethical structure may trigger fraudulent actions. Some structural red flags displayed by the companies are listed below (Coenen (2008), Farrager and Nelder (2001), and Chartered Institute of Management Accountants' Fraud Risk Management - A guide to good practice booklet (2001)):

- Not having a reliable control framework,

- Absence of policies such as anti-fraud, code of business conduct, etc.

- Lack of management supervision,

- Concentration of duties in certain individuals, lack of segregation of duties and inadequate staffing,

- Lax rules regarding authorization of transactions,

- Lack of competitive bids,

- Limited or no supporting documentation for transactions, 
- Inadequate delivery proofing,

- Sole sourcing of specific contractors and vendors for both national and international projects.

\subsubsection{Internal Indicators of Fraud Risks - Employee Behaviors}

There are some certain behaviors that may indicate that someone is included in a fraudulent act. These certain behaviors are also called Red Flags.

Some of the red flags displayed by potential fraudsters are listed below (Association of Certified Fraud Examiners' Report to the Nations on Occupational fraud and Abuse (2010), Wells (2003), Farrager and Nelder (2001)):

- Living beyond financial means,

- Unexplained increase in wealth,

- Close relationship with vendors,

- Experiencing financial difficulties,

- Unwillingness to share duties,

- Addiction problems,

- Extraordinary medical expenses,

- Significant, regular cash expenses for entertainment and/or travel,

- Refusal to take vacations,

- Complained about inadequate pay,

- Short vacations and unexplained working hours.

Moreover, human resources structure and employee relations may also indicate fraud risk. According to the Chartered Institute of Management Accountants' Fraud Risk Management - A guide to good practice booklet (2001), the most common situations which may end up with internal fraud are: 
- Strained relationships between employees,

- Low employee morale and satisfaction,

- High turnover in the key positions of the company.

\subsubsection{External Indicators - Market Conditions}

There are some issues which are not directly related with the company or its employees; however, may put the company under fraud risk. Some of the external indicators are listed below (Chartered Institute of Management Accountants' Fraud Risk Management - A guide to good practice booklet, 2009):

- Introducing a new regulatory authority including new health/safety or environmental legislations,

- Bureaucratic obstacles,

- Competitive market conditions and decreasing profitability levels within the organization,

- High pressure from the shareholders to meet the performance targets.

In conclusion, presence of any of the abovementioned behaviors and properties does not mean that internal fraud actually exists within the company. However, if companies encounter any of abovementioned indicators, they should be more curious to seek for fraudulent acts.

\subsection{Types of Internal Fraud}

Anyone who seeks an illegal financial gain may participate in a fraudulent act regardless of the magnitude of loss of the victim parties. For instance; siphoning off a bank by the bank owners causes significant damages to lots of individuals, on the other hand damage caused by an employee's falsified work expense report is less damaging. However, both examples are accepted as fraudulent acts. 
There are different types of internal frauds; however the aim of this study is to understand the most common types of employee fraud schemes against employers in the construction sector. In order to identify the most common employee fraud schemes; previous studies, surveys and experiences of individuals in the construction sector are used.

Main fraud types discussed in the following parts are: financial statement fraud, asset misappropriation and kickback/bribery.

\subsubsection{Financial Statement Fraud}

In Fraud Examiners Manual of ACFE (2008), financial statement fraud is identified as "deliberate misrepresentation of the financial condition" of the company by "intentional misstatement and omission of the amounts or disclosures".

Financial statement fraud is not a common internal fraud type. However, the magnitude of the damage caused by financial statement fraud is generally much more significant than the other types of internal fraud. According to Association of Certified Fraud Examiners' Report to the Nations on Occupational fraud and Abuse (2010), median of the loss amount caused by financial statement fraud is USD 4,100K. Moreover, financial statement fraud also creates other damages such as loss of reputation, potential fines and accusations.

Fraudster aims to manipulate the financial status of the company in order to show that the predetermined targets were achieved especially if the company offers performance based bonuses.

Sometimes financial statement fraud is applied to provide illegal advantages for the company. For instance, companies may misrepresent their financial conditions in order to finance their company or to be able to apply to tenders. 
In construction contracts, especially in governmental deals, contractors may understate revenues and/or overstate expenses to request excess payment over the amount of the work performed. For instance, in cost plus fee contracts, costs are overstated in order to charge excessively and in lump sum contracts, overstated costs may be used for bargaining to increase the lump sum amount.

\subsubsection{Asset Misappropriation}

According to Black's Law Dictionary, misappropriation is "the act of misappropriating or turning to a wrong purpose; wrong appropriation, a term that doesn't necessarily mean peculation, although it may mean that. The term may also embrace the taking and using of another's property for sole purpose of capitalizing unfairly on good will and reputation of property owner". Black's Law Dictionary's definition is a broad definition which clearly identifies misappropriation. However, asset misappropriation is simply misusing company's assets for personal purposes or stealing the assets from the company's premises.

Fraudster may use both tangible and intangible assets of the company for personal purposes. Using vehicles, computers, office supplies and equipments are some examples for misusing tangible assets. On the other hand, sharing expertise of the company such as planning models, pricing models, etc., with competitors is a type of intangible asset misappropriation.

Theft is the other type of asset misappropriation. Theft is the physical movement of an asset belonging to the company to employee's control. Stealing cash/inventory or bringing away customer/vendor information are some examples of employee theft.

\subsubsection{Kickback/Bribery}

TI defines kickback or bribery as offering, promising, giving, accepting or 
soliciting of an advantage as an inducement for an action which is illegal or a breach of trust. Besides, Jong et al. (2009) characterized the bribe or kickback requesting individual as someone who has the power to make favorable decisions for the ones who are seeking favorable decisions. Kickback/bribery schemes could be initiated either by the employee via asking or by the vendor via offering valuable incentives such as money (onetime payment or commissions), gifts, loans, etc.

Jong et al. (2009) mentioned that kickbacks/bribes are not only demanded by regulatory officials but also could be sought by contractors' empowered employees or engineers from the sub-contractors or material providers of the contractors. Kickback reveals when a contractor or vendor transfers a financial benefit in order to influence a business decision (Farrager and Nelder, 2001).

If an employee is responsible from procurement, he/she should obtain the best price from the vendors on behalf of the company. However, in kickback/bribery schemes employee accepts or secures acceptance of inflated or falsified invoices of a particular vendor and shares the illegal benefit with the vendor (Coenen, 2008). Invoices used in kickback/bribery schemes are mostly based on overstating the prices of materials/services or consisting fictitious materials/services. Some common methods used in kickback/bribery schemes are listed below.

- Overstating labor work hours,

- Overstating machinery usage hours,

- Charging for higher quality materials than provided for the project,

- Charging for higher quality machinery and equipment than the ones used in the project,

- Charging for services or materials that were never provided,

- Charging for the costs of counterfeit change orders,

- Overstating the cost of the change orders. 
Kickback/bribery schemes may cause significant losses to the victim company such as obtaining services/materials with higher prices (or not obtaining them at all), obtaining inferior products or services in lieu of the technical specifications of the contract. Moreover, obtaining materials/services which are not in line with the specifications may cause penalties. When the losses of the victim company are considered, it is obvious that the damage on the victim company is much more significant than the illegal benefit obtained by the corrupt employee.

Durant (2005) stated that bribery issues during procurement phase often go undetected, uninvestigated and unpublicized. These issues go undetected because the issues include the parties who are responsible from the transactions, go uninvestigated because contractors doubt whether they will be able to recover the loss so they do not prefer to spend money for the investigation and go unpublicized since the management of the contractor does not want the occurrence of fraud to be known.

Vendor selection method has its own fraud risks when kickback/bribery schemes are considered. Main vendor selection methods and the risks included in these processes are discussed below.

\subsubsection{Fraud Schemes in Vendor Selection through Negotiation (Single Sourcing)}

Single sourcing means using a sole source form procurement through solicitation of a proposal. In this type of procurement, no bidding process is applied; it is based on the negotiations between empowered the employees of the employer and potential vendors. This type of procurement is much more subject to the risk of fraud compared to competitive bidding.

In single sourcing, the empowered employee/department has the right to select the vendor through negotiation and evaluation. However, single sourcing sustains 
some internal fraud risks. For instance; vendor and the employee/department may establish a kickback/bribery scheme and the scheme may be used by the employee to provide illegal gain and by vendor to provide materials/services with higher prices or with lower than the required quality.

Sometimes vendor pays kickback to the employee only to establish a trade relationship with the employer by providing materials or services with acceptable prices. In this case, vendor uses kickback only to establish trade relationship, so it may seem harmless for the company at the beginning. However, in time, the vendor may lose its incentives to provide materials/services with acceptable prices and at the required quality.

There are several reasons for not being able to prevent this problem. It is costly to establish a the procurement process in consideration with segregation of duties principle. Therefore, in most of the companies, employees have a number of responsibilities conflicting with each other which creates significant fraud risk for the company (Durant, 2005).

\subsubsection{Fraud Schemes in Competitive Bidding Process}

Competitive bidding is a process which is used to acquire materials and/or services which meet the needs (quality, quantity, time, location) of purchaser with the best possible total cost. Thus, there is a competition between the vendors to provide specified materials and/or services. In order to avoid potential negative influences of vendors throughout the bidding process, there are predefined terms and conditions of processes and procedures that bidders are obliged to follow.

In bid rigging scheme, it is aimed to influence the results of the bidding process in favor of a particular vendor by using an authority that have rights on the bidding process. For construction business, these authorities can be contracting officials, engineers and other technical staff, QA/QC representatives or anyone else in the 
bidding process.

There are two main ways of bid rigging. These ways are as follows (Faraggher and Nelder, 2001):

- Providing insider information that may be used as a guidance to win the bidding process,

- Establishing pre-qualification factors or specifications according to a particular vendor in order to make the vendor win the bidding or to exclude its competitors.

Bid rigging can occur in any phase of the bidding process. These phases could be categorized as pre-solicitation, solicitation-negotiation and submission. The risks related to these phases are discussed below.

\subsection{Bid Rigging in Pre-solicitation Phase}

In this phase, the types and specifications of materials and/or services that are going to be procured are determined.

There are two main types of bid rigging schemes that can occur in this phase. One of them is convincing the purchasing entity about the necessity of a purchase, which is also called need recognition schemes. The second type of scheme is using the power to tailor the specifications and requirements according to a particular vendor which is called specification schemes.

There are some red flags that may indicate the risk of bid rigging scheme in presolicitation phase. In case of existence of the following situations, the contractor should pay attention (Chartered Institute of Management Accountants' Fraud Risk Management - A guide to good practice booklet (2009), Farrager and Nelder (2001)). 
- Splitting the same work into pieces in order to bypass internal controls,

- Specifications and statements of work which only suits with the products or capabilities of a specific single supplier,

- Specifications and statements of work developed by a specific contractor or consultants who will be permitted to bid and perform on the contract,

- Specifications which are not consistent with similar past procurements, or unusual - unreasonable specifications for the type of materials and/or services being procured,

- Specifications that do not make commercial sense,

- Contracts that include special, but unnecessary specifications that only particular vendor can meet,

- Defining single brand name rather than defining general description,

- Defining vague specifications which may lead to more money claims,

- Personal relationships between staff and vendors.

\subsection{Bid Rigging in Solicitation-Negotiation Phase}

Solicitation-Negotiation phase consists of bidding and contract awarding processes. There are also some red flags that may indicate that the bid was rigged. These red flags are stated below (Chartered Institute of Management Accountants' Fraud Risk Management - A guide to good practice booklet (2001), Farrager and Nelder (2001)).

- Announcing limited time for submission of bids, therefore only the ones who has advance information have adequate time for preparation,

- Publishing bid solicitation during holidays, and publishing vague information about the time, place and date or other requirements for submitting bids,

- Failure to adequately publicize request for bids by using obscure publications, and failure to inform potential competitors, 
- Short invitation list for tender and consistent favoring of certain vendors over others,

- Unchanging list of preferred vendors,

- Announcing flexible and nebulous evaluation criteria,

- Announcing changes to the bid specifications after bid opening,

- Accepting late bids,

- Accurate estimations of tender costs by certain bidders,

- Disqualification of suitable bidders from bids without apparent reasons and sub-contracting to higher bidders,

- Awarding contracts to vendors disproportionate to their size,

- Awarding the contract to a vendor with a poor performance record,

- Awarding the contract to a vendor who has good relationships with an employee or a relative of an employee,

- Poor documentation of the contract award process,

- Assisting the vendor while preparing the bid,

- Referring a vendor to a specific third party as an expert or consultant,

- Indication of collusion between bidders such as rotating the bids by submitting the lowest bid by exchanging the information,

- Falsification of vendor's credentials, financial capabilities, qualifications, work history, equipment or employees.

\subsection{Bid Rigging in Submission Phase}

Submission phase of the bid is the period after awarding the contract to a bidder. In this phase, there are also some indicators of bid rigging after the award of contract such as:

- Unexplained changes in the specifications and the scope of work in the contract shortly after its awarded,

- Decrease in the limits of liability of vendor after the award of the contract. 


\subsubsection{Reasons for Not Preventing Kickback/Bribery Schemes}

The most important reason of not being able to prevent kickback/bribery schemes is not having reliable purchasing and procurement policies such as not obtaining written proposals from multiple vendors. Being deficient in applying segregation of duties principle such as not being able to separate parties that are responsible from vendor selection and purchase order is another important reason of not being able to prevent kickback/bribery schemes (Durant, 2005).

\subsubsection{Facilitation Payments}

Argandoña (2005) described the use facilitation payments as "the act and effect of giving or receiving a thing of small value in order that a public official or employee does or omits to do something, or does it faster and more effectively or more slowly and less effectively, circumventing a formal or implicit rule about what that official or employee ought to do or not do, to the benefit of the person who gives the thing of value or a third party, to help resolve a matter, expedite an administrative process, secure the issuance of a license, permit or service, etc., but not to obtain or retain business, a contract or a business transaction or to obtain a major competitive advantage”. Similarly according to Anti-corruption Code of Conduct of Asia Pacific Economic Consortium (APEC), facilitation payments are small unofficial payments made in order to secure or speed up the standard process.

As a result, facilitation payments are small unofficial payments or gifts made to public officials or empowered employees of companies in order to speed up the standard processes.

Some characteristics of facilitation payments are described below (Argandoña, 2005): 
- Facilitation payment is made in order to expedite an administrative matter or assure the issuance of a permit or license,

- Facilitation payment is received usually by a public officer or a low level employee who has minimal power,

- Total amount of the payment or the value of the gift is small,

- Widespread especially in developing countries,

- If used as bribery, it is prohibited and criminalized,

- Paid privately.

The main difference between facilitation payments and bribery is that facilitation payments are made to expedite the process of which the payer is entitled and the payer does not request something illegal or immoral whereas bribe is used to provide unmerited gains.

OECD Convention on Combating Bribery of Foreign Public Officials in International Business Transactions prohibited bribing foreign public officials. However, according to Argandoña (2005), the official commentaries of the convention excludes "small facilitation payments" made in order to "induce public officials to perform their functions, such as issuing licenses or permits'. However, it is hard to differentiate the facilitation payment from bribery and therefore, it is very important to be aware of the nature of the payments called facilitation payments to prevent unpleasant results.

\subsubsection{Ghost Employees}

Someone who is on the payroll but does not actually work is called a ghost employee. Ghost employee is put on the payroll by the employee who is responsible from the payroll and the company starts to make salary payments. In most cases, ghost employee is a friend or relative of the fraudster. If the victim company is making salary payments in cash fraudster may use the names of 
recently departed employees and make fictitious salary payments to their names as well.

\subsubsection{False Compensation Claims}

After work accidents, dishonest employees may request disability payments and more for fictitious injuries or they may work for another full time job while they are getting payments to rest and recover from the victim company.

\subsection{Fraud Prevention}

Fraud and misconduct may occur at various levels in any organization. In order to prevent fraud, appropriate preventive and detective techniques should be developed and established. In the following parts of the study, appropriate preventive and detective approaches against internal fraud are discussed. Having following preventive measures does not mean that fraud is prevented certainly. However, having the following preventive measures will help the companies to decrease internal fraud risk considerably.

With the help of the following measures; companies may increase reliability of financial statements, comply with laws/regulations and decrease internal fraud risk.

\subsubsection{Segregation of Duties Principle}

Segregation of duties principle stands for separating business functions that may conflict. Some of the functions that should be segregated to different employees/parties are:

- Purchasing and payment functions,

- Purchase order and vendor selection functions, 
- Vendor selection and accepting goods functions.

According to the Fraud Examiners Manual of ACFE (2008), each company, regardless of its size, should separate purchasing and payment processes and functions. Especially for the purchasing function, Fraud Examiners Manual of ACFE (2008) highlighted the importance of having a separate purchasing department for the companies especially for the ones which have enough human resources.

\subsubsection{Employee Selection}

Employee selection is a proactive measure in order to prevent potential fraud risks. Wells (2003) recommended conducting background checks for any potential employee, especially for prospective employees of accounting, inventory management and vendor selection.

Some important checks that should be applied before hiring a potential employee are listed below:

- Education and certificate verification,

- Past employment verification,

- Personal references verification,

- Criminal conviction checks.

Moreover, after employee was hired, regular controls should be carried on to review the compliance of the employee to corporate values and to code of conduct of the company. 


\subsubsection{Internal Audit}

The IIA's Definition of Internal Auditing states that "Internal auditing is an independent, objective assurance and consulting activity designed to add value and improve an organization's operations. It helps an organization accomplish its objectives by bringing a systematic, disciplined approach to evaluate and improve the effectiveness of risk management, control, and governance processes". Green and Calderon (1996) also mentioned the substantial role of internal audit in fraud detection and fraud risk assessment. Substantial fraud risk assessment processes through internal audit are described below.

- Identifying company assets to protect: Identifying and prioritizing the assets of the company,

- Identifying the possible threats: Identifying possible fraudulent acts such as misappropriation of inventory and equipment, bid rigging, conflicts of interest, corruption, and financial statement fraud,

- Determining probability of occurrence: Assessing the likelihood of each type of fraud in the organization and gathering all available empirical evidences of fraud such as prior fraud incidents, unexplained losses, audit findings, and complaints,

- Determining impact of loss: Determining the impact of loss if incurred.

- Establishing necessary controls: Identifying the controls that should be applied in order to prevent potential fraud incidences,

- Periodic checks: Checking the appropriateness and functioning of the controls periodically.

In order to provide control environment in place; as Murdock (2008) stated, internal auditor should be aware of the needs, opportunities and justifications which may cause fraudulent acts. Moreover, internal audit should reveal the significant changes in employee needs, effectiveness of internal controls, 
management's competence, consistency, objectivity, documentation, and transparency to identify fraud risks. On the other hand, internal auditors should help management to establish anti-fraud programs. These programs should consist of necessary steps such as deterrence, prevention, detection, and investigation of fraud.

\subsubsection{Whistle-blowing}

A broad definition of whistle-blowing is the disclosure of wrongdoing by either existing or former employees of the company and the one who blows the whistle is accepted as the whistleblower. Australian Whistleblower Programs for Entities defines the whistleblower as " a person being a director, manager, employee or contractor of an entity who, whether anonymously or not, makes, attempts to make or wishes to make a report in connection with reportable conduct and where the whistleblower wishes to avail themselves of protection against reprisals for having made the report. A whistleblower may or may not wish to remain anonymous". Hauserman (1986) briefly explained whistleblower as the person who reports a real or perceived wrongdoing of his or her employer or super ordinates.

Bayar (2003) stressed the importance of encouraging and protecting whistleblowers while combating corruption and mentioned that whistleblowers need to be protected from possible retaliations by providing them a secure environment.

According to Association of Certified Fraud Examiners' Report to the Nations on Occupational fraud and Abuse (2010), more than $40 \%$ of the respondents stated that internal fraud is mostly detected by tips. It was also stated that previous surveys by ACFE also revealed the importance of tips while detecting internal fraud. Although tips are the most common way of detecting fraud, many companies do not implement fraud reporting systems such as hotlines. These 
systems enable employees to blow whistle anonymously and make whistleblowing process more efficient.

Establishing anonymous reporting systems is the key point, because employees often avoid reporting which may result with the threat of retaliation or negative reactions. Therefore, using anonymous reporting systems is an effective way to encourage employees to give tips.

There are some models around the world for protecting whistleblowers. USA's Whistleblower Protection Act and False Claims Act, South Australian Whistleblower Protection Act, The New South Wales Protected Disclosures Act and UN Convention against Corruption are examples of some governmental models to protect whistleblowers.

According to Association of Certified Fraud Examiners' Report to the Nations on Occupational fraud and Abuse (2010), implementation of fraud reporting hotlines are positively correlated with the number of cases detected by a tip. $47 \%$ of the fraud cases were detected by tips in the organizations using hotlines. In contrast, only $34 \%$ of cases were detected by tips in the organizations without hotlines. This comparison illustrates the importance of anonymous fraud reporting systems while detecting fraud.

In order to establish a "whistle-blowing culture" in an organization, there are some necessities listed below (Ravishankar, 2010):

- Policies for reporting illegal or unethical practices should be created,

- Commitment of top management should be demonstrated,

- Commitment of the organization to ethical behavior should be publicized by memos, newsletters and speeches to the employees,

- Employees raising ethical issues should be rewarded, 
- Allegations should be followed up all promptly and thoroughly,

- Internal whistle-blowing system should be continuously assessed.

\subsubsection{Code of Ethics and Code of Business Conduct}

Establishing an ethical environment and setting rules with codes of business conducts are other important proactive measures to prevent internal fraud.

Several organizations and companies developed codes of ethics and business conducts according to their requirements. ASCE also developed Standards of Professional Conduct of ASCE in order to guide its members. The Code of Conduct for Engineers is an important part of these standards. This code includes seven fundamental standards, four of which are related to the prevention of internal fraud and corruption.

- Engineers shall issue public statements only in an objective and truthful manner,

- Engineers shall act in professional matters for each employer or employer as faithful agents or trustees, and shall avoid conflicts of interest,

- Engineers shall build their professional reputation on the merit of their services and shall not compete unfairly with others,

- Engineers shall act in such a manner as to uphold and enhance the honor, integrity, and dignity of the engineering profession.

Only the companies which want to outline the behaviors expected from employees and the proper procedures that should be applied in the company try to develop their own codes of business conduct. However, every organization should create and maintain a code of business conduct in order to guide employees' behaviors and to prevent fraudulent acts. Bierstaker et al. (2006) mentioned that the fraud policies should be separate and distinct from the code of business 
conducts and also communicated clearly to the employees.

Proper code of business conduct should prohibit the following actions:

- Accepting gratitude, expensive gifts or lavish entertainments from vendors,

- Developing conflict of interest,

- Disclosing trade secrets to third parties,

- Falsifying documents such as attendance reports, expense reports, etc.,

- Related party transactions,

- Other illegal acts.

\subsubsection{Periodic Vendor Contract Reviews}

Periodic reviews on the contracts and previous bids may reveal the possible contract frauds. The red flags in different phases of contracts were discussed under Kickback/Bribery ${ }^{20}$ part.

There are some red flags that may indicate that the vendor is included in an improper scheme. It is beneficial to be curious for the vendors which are:

- Regularly being awarded,

- Regularly bidding last,

- Regularly bidding lowest,

- Having good relationships with key employees.

\subsubsection{Periodic Job Rotations}

Implementing a job rotation system limits fraud exposure and may reveal prior

${ }^{20}$ Please refer to Part 3.8.3. Kickback/Bribery 
fraud attempts. Job rotation procedures are also beneficial for socialization and creating cross trained employees (Gupta and Govindarajan, 1991).

\subsubsection{Internal Training}

Fraud awareness trainings for employees, managers and executives are very crucial for developing a fraud insight within the company.

There are some training projects developed by organizations. One of them is the Global Anticorruption Education and Training Project which was funded by ASCE. This project focuses on eliminating fraud, bribery, and corruption from engineering and construction sector. Some topics carried out by the project are:

- Corruption engineering and construction sector,

- Fraud and bribery engineering and construction sector,

- The concepts of fighting corruption,

- Ethical dilemmas involving corruption,

- Anticorruption guidelines. 


\section{CHAPTER 4}

\section{INTERNAL FRAUD QUESTIONNAIRE}

This chapter illustrates the results of fraud survey which was implemented on Turkish construction contractors. This survey was implemented to Turkish construction contractors in order to understand following issues:

- Fraud awareness of construction companies,

- The proactive measures of the construction companies to prevent fraud,

- The common fraud types that the construction companies face with,

- The reactions of the construction companies after fraud cases.

This survey was performed by using a questionnaire. The questionnaire consists of twenty-four questions, seven of which aim to gather information about the respondent and the company. These seven questions are very crucial to understand the relationship between respondent profile and survey results.

The questionnaire was distributed online via a web page. The survey was prepared on a professional survey web site, www.surveymonkey.com/s/odtu_tez_anketi. This professional web site was also linked to http://www.metu.edu.tr/ e124069/ served by Middle East Technical University. The results were collected by the professional survey web site anonymously and at the end of the surveying period, data including the results were extracted from the professional survey web site. Please refer to Appendix A for the sample questionnaire.

The responses were collected anonymously. However, due to the tense subject of 
the survey, some people avoided completing the questionnaire.

\subsection{Respondents' Characteristics}

The total number of attendants of the survey was 89 . In the following parts, main characteristics of the survey respondents, the companies that respondents are working for ("the Company") ${ }^{21}$ and respondents' ideas are discussed by using descriptive statistics on survey results.

\subsubsection{Positions of Respondents}

The questionnaire was mainly responded by the members of top management and the members of construction teams (including project manager, technical office chief and site chief) of the companies. Following table illustrates the distribution of the roles of the respondents.

Table 9: Positions of the respondents

\begin{tabular}{|l|r|r|}
\hline Position & $\begin{array}{r}\text { Number of } \\
\text { respondents }\end{array}$ & $\begin{array}{c}\text { \% of total number } \\
\text { of respondents }\end{array}$ \\
\hline Technical office chief & 26 & 29.2 \\
\hline Owner / shareholder / member of board of directors & 17 & 19.1 \\
\hline Site chief & 14 & 15.7 \\
\hline Project manager & 13 & 5.6 \\
\hline Administration manager / procurement manager & 5 & 4.5 \\
\hline General manager / general coordinator & 4 & 4.5 \\
\hline Internal auditor & 3 & 3.4 \\
\hline Finance manager & 3 & 3.4 \\
\hline Human resources manager & & 5.6 \\
\hline
\end{tabular}

\footnotetext{
${ }^{21}$ In the following chapters, "the Company" or "the Companies" stands for the companies that the respondents are working for.
} 


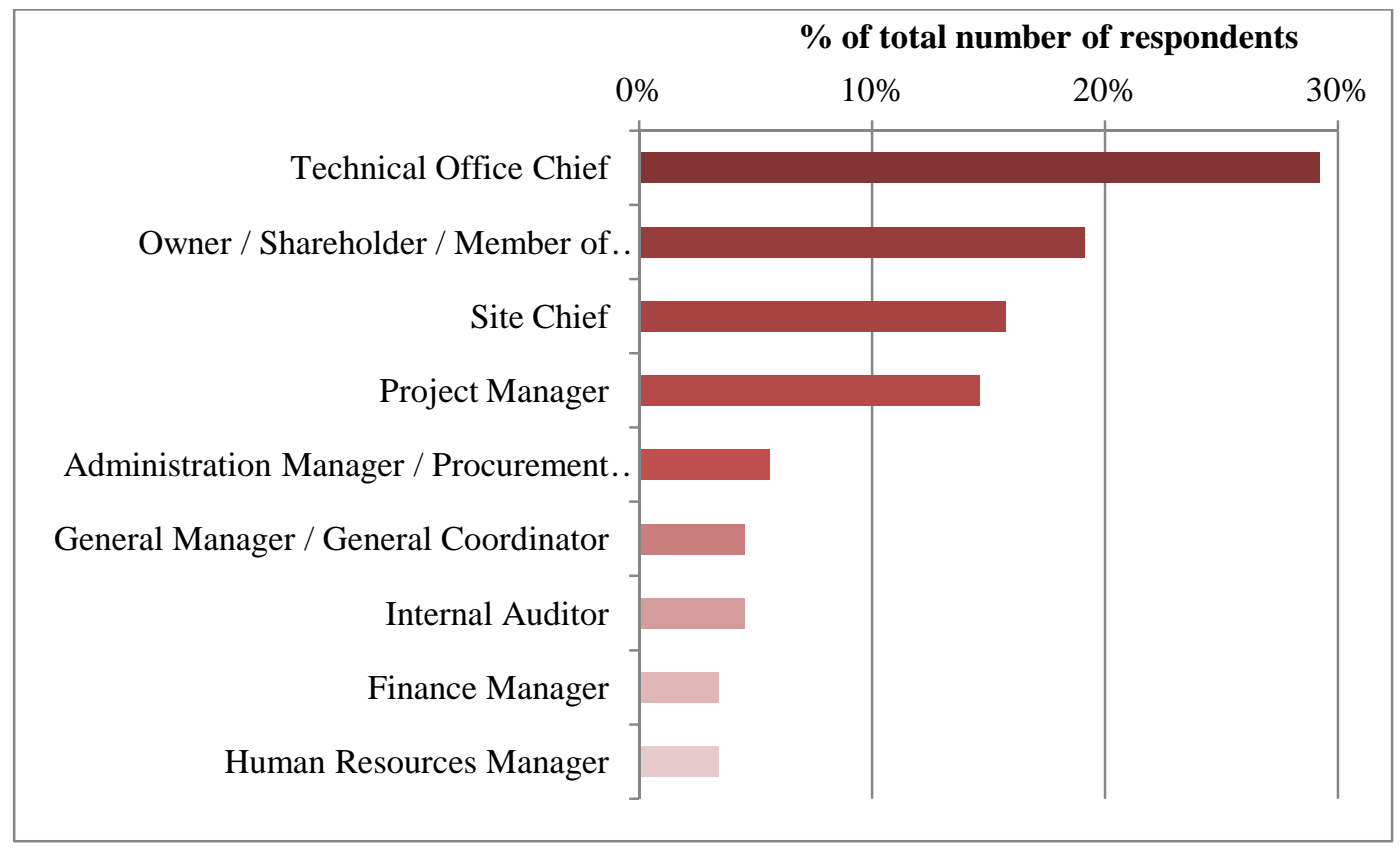

Figure 2: Positions of the respondents

As depicted above, most of the respondents were from operational functions and few of them were from supporting functions.

\subsubsection{Size/Volume of the Companies}

In the second question, it was aimed to understand the size of the Companies by asking the number of employees working in the headquarters of the Company. Below table illustrates the number of employees working in the headquarters and their respective percentages. 
Table 10: Number of employees working in the headquarters of the Companies'

\begin{tabular}{|l|c|c|}
\hline Number of employees & $\begin{array}{c}\text { Number of } \\
\text { respondents }\end{array}$ & $\begin{array}{c}\text { \% of total number of } \\
\text { respondents }\end{array}$ \\
\hline $1-25$ & 27 & 30.3 \\
\hline $26-50$ & 15 & 16.9 \\
\hline$>51$ & 47 & 52.8 \\
\hline
\end{tabular}

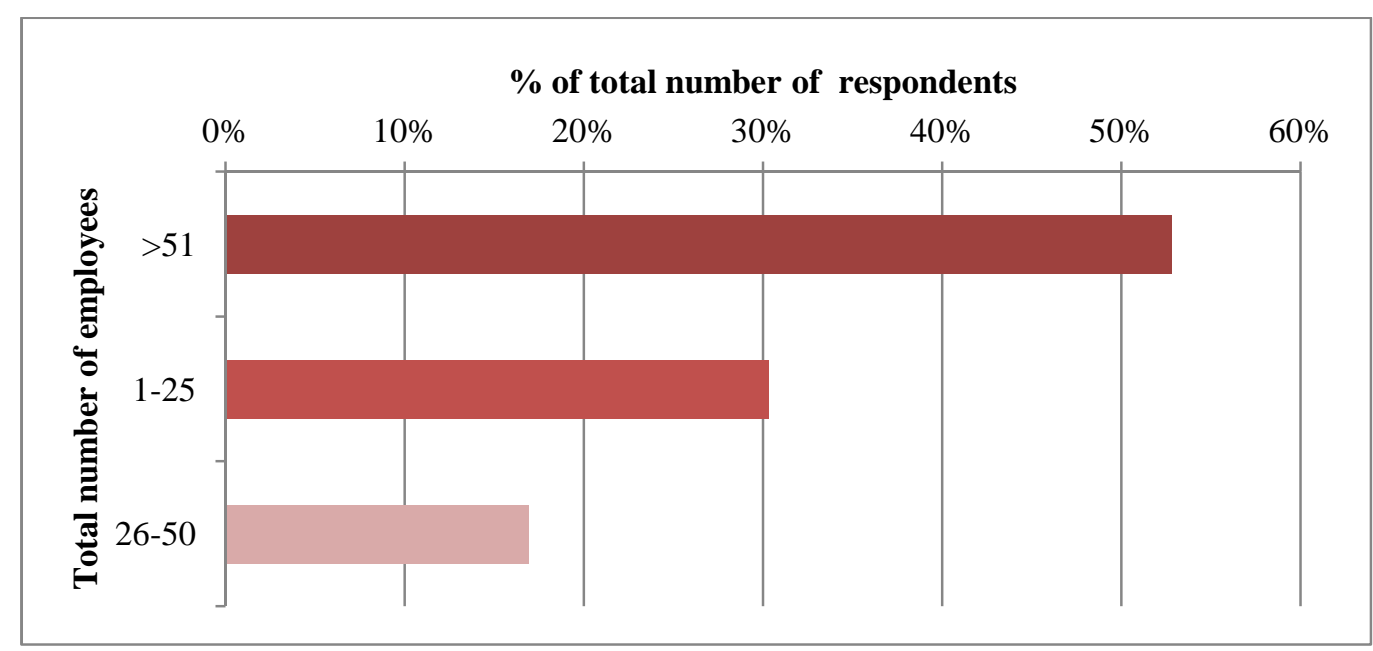

Figure 3: Number of employees working in the headquarters of the Companies

More than half of the companies had at least fifty-two employees in their headquarters. Moreover, if the companies were grouped according to the number of employees such as small companies (1-25), medium companies (26-50) and large companies $(>51)$, it is seen that most of the companies were medium and large companies.

Another question was the average revenue of the company from construction projects in the last three years. This question was also asked to understand the volume of the Company. Below table illustrates the Companies' average annual revenues and their respective percentages. 
Table 11: Annual average revenues of the Companies (Average of last three years)

\begin{tabular}{|l|c|c|}
\hline $\begin{array}{l}\text { Annual revenue of the } \\
\text { company (TL) }\end{array}$ & $\begin{array}{c}\text { Number of } \\
\text { respondents }\end{array}$ & $\begin{array}{c}\text { \% of total } \\
\text { number of } \\
\text { respondents }\end{array}$ \\
\hline$<15 \mathrm{M}$ & 32 & 36.0 \\
\hline $15 \mathrm{M}-100 \mathrm{M}$ & 19 & 21.3 \\
\hline$>100 \mathrm{M}$ & 38 & 42.7 \\
\hline & 89 & 100.0 \\
\hline
\end{tabular}

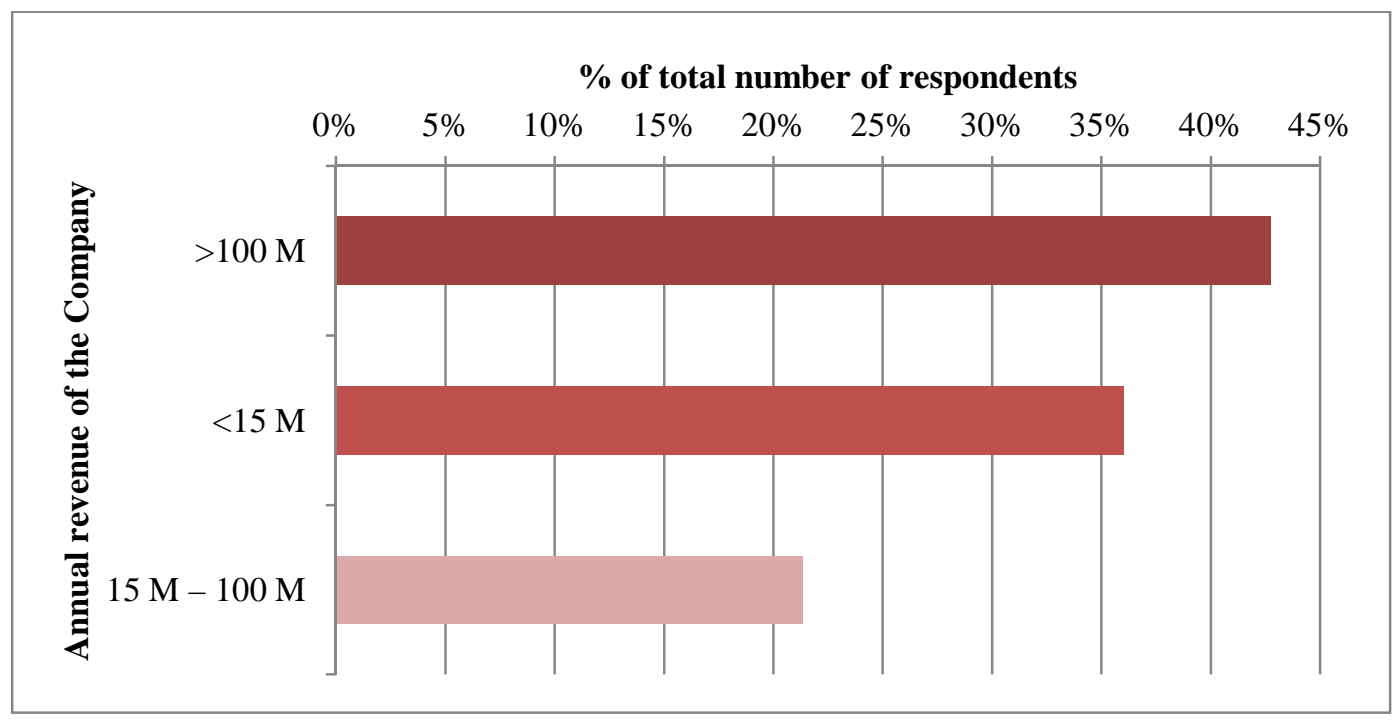

Figure 4: Annual average revenues of the Companies

According to the above figure, it is seen that almost $40 \%$ of the Companies had an average revenue of more than TL $100 \mathrm{M}$ from construction projects in the last three years. 


\subsubsection{Type and Place of Contracts and Expertise Areas of the Companies}

There were some questions in the survey related with the type and place of contracts and expertise areas of companies.

First question was the main contract type performed by the Companies. Below table shows main contract types signed by the Companies.

Table 12: Main types of contracts signed by the Companies (in the last three years)

\begin{tabular}{|l|c|c|}
\hline Type of contract & $\begin{array}{c}\text { Number of } \\
\text { respondents }\end{array}$ & $\begin{array}{c}\text { \% of total } \\
\text { number of } \\
\text { respondents }\end{array}$ \\
\hline Main contractor & 63 & 70.8 \\
\hline Sub-contractor & 14 & 15.7 \\
\hline Joint venture & 9 & 10.1 \\
\hline Main contractor $(50 \%)$ - joint venture $(50 \%)$ & 2 & 2.2 \\
\hline Main contractor $(50 \%)$ - sub-contractor $(50 \%)$ & 1 & 1.1 \\
\hline Total & 89 & 100.0 \\
\hline
\end{tabular}

According to above, table it is seen that nearly $70 \%$ of the Companies working as main contractors.

Number of expertise areas was another question to understand the number of different fields that the Company was doing projects in. In order to be consistent in the answers, the construction fields were predefined as:

- Superstructures,

- Infrastructures, 
- Industrial structures,

- Mechanical works,

- Electrical works,

- Airports/seaports/railways,

- Dams/ Hydro-electric plants.

Below table shows the number of fields that the company had projects in during the last three years.

Table 13: Number of expertise areas of the Companies

\begin{tabular}{|l|c|c|}
\hline $\begin{array}{l}\text { Total number of } \\
\text { fields }\end{array}$ & $\begin{array}{c}\text { Number of } \\
\text { respondents }\end{array}$ & $\begin{array}{c}\text { \% of total number of } \\
\text { respondents }\end{array}$ \\
\hline 1 & 39 & 43.8 \\
\hline 2 & 32 & 36.0 \\
\hline$>2$ & 18 & 20.2 \\
\hline
\end{tabular}

Nearly $80 \%$ of the Companies performed projects in at most two different fields.

The last question was about whether the Company performed a construction project abroad in the last three years. Below table shows the number of the Companies that performed construction projects abroad and their respective percentages. 
Table 14: The Companies that performed construction projects abroad

\begin{tabular}{|l|c|c|}
\hline $\begin{array}{c}\text { The Company carried out a } \\
\text { construction project abroad }\end{array}$ & $\begin{array}{c}\text { Number of } \\
\text { respondents }\end{array}$ & $\begin{array}{c}\text { \% of total number of } \\
\text { respondents }\end{array}$ \\
\hline Yes & 58 & 65.2 \\
\hline No & 31 & 34.8 \\
\hline
\end{tabular}

\subsubsection{Fraud Risk Awareness of the Respondents}

Several questions were asked to the respondents in order to understand the fraud risk awareness of the respondents about following subjects:

- Are the construction companies under the risk of fraud?

- Which level of employees is most likely to commit fraud?

- Which prevention methods are the most effective?

- Which fraud types are likely to occur in the construction sector?

The first question was whether the respondents thought that the Companies that they were working for were whether under the risk of fraud. Below table shows the number of respondents who think the Company is under the risk of fraud.

Table 15: Respondents think the Companies are under the risk of fraud

\begin{tabular}{|l|c|c|}
\hline $\begin{array}{l}\text { Is your company under } \\
\text { the risk of fraud? }\end{array}$ & $\begin{array}{c}\text { Number of } \\
\text { respondents }\end{array}$ & $\begin{array}{c}\text { \% of total number } \\
\text { of respondents }\end{array}$ \\
\hline Yes & 38 & 42.7 \\
\hline No & 51 & 57.3 \\
\hline
\end{tabular}




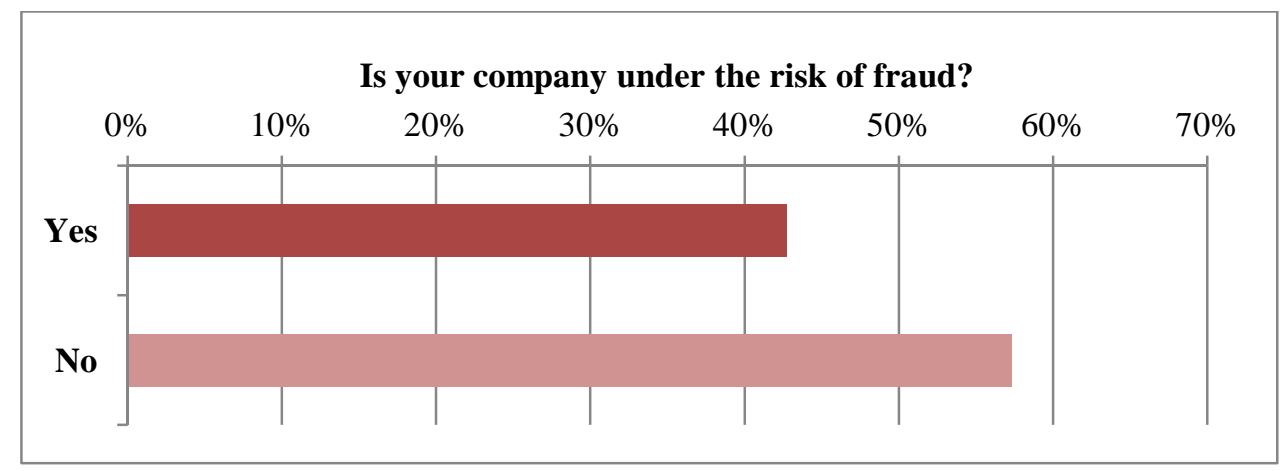

Figure 5: Respondents think the companies are under the risk of fraud

Almost $40 \%$ of the respondents stated that they thought that the Companies that they are working for are under the risk of fraud.

Second question was about the level of employees which are likely to commit fraud. Below table shows the responses on the level of employees which are likely to commit fraud.

Table 16: Level of management most likely to commit fraud

\begin{tabular}{|l|c|c|}
\hline $\begin{array}{l}\text { Level of management most likely to } \\
\text { commit fraud }\end{array}$ & $\begin{array}{c}\text { Number of } \\
\text { respondents }\end{array}$ & $\begin{array}{c}\text { \% of total number of } \\
\text { respondents }\end{array}$ \\
\hline Do not know & 24 & 27.0 \\
\hline Middle Management & 19 & 21.3 \\
\hline Junior Management & 17 & 19.1 \\
\hline Senior Management & 11 & 12.4 \\
\hline Blue Collared & 9 & 10.1 \\
\hline Do not want to answer & 9 & 10.1 \\
\hline
\end{tabular}

Nearly $40 \%$ of the respondents selected either Middle Management (managers, 
etc.) or Junior Management (chiefs, etc.).

Effectiveness of the fraud prevention methods is another subject which was inquired to the survey respondents. A list of fraud prevention methods was prepared and respondents were asked to assign an effectiveness level to each fraud prevention method ('Not at All Likely', 'Likely' and 'Extremely Likely'). Below table summarizes the effectiveness levels of each fraud prevention method according to the respondents.

Table 17: Effectiveness of fraud prevention methods

\begin{tabular}{|l|c|c|c|}
\hline \multirow{2}{*}{ Fraud prevention method } & \multicolumn{2}{|c|}{ Likeliness to prevent fraud } \\
\cline { 2 - 4 } & $\begin{array}{c}\text { Extremely } \\
\text { likely }\end{array}$ & Likely & $\begin{array}{c}\text { Not at all } \\
\text { likely }\end{array}$ \\
\hline Internal audit & 61 & 14 & 14 \\
\hline External audit & 57 & 22 & 10 \\
\hline $\begin{array}{l}\text { Implementing segregation of duties } \\
\text { principle }\end{array}$ & 57 & 18 & 14 \\
\hline Management reviews - periodic reporting & 45 & 29 & 15 \\
\hline Periodic rotation of employees & 29 & 23 & 37 \\
\hline Internal training & 28 & 26 & 35 \\
\hline Encouragement and protection of & 25 & 16 & 48 \\
whistleblowers and whistle-blowing \\
hotlines
\end{tabular}

Internal and external audits were selected as the most effective fraud prevention methods. Audits are followed by implementing segregation of duties principle and management reviews.

The last question was about the types of fraud which are most likely to occur in 
the construction sector. Similar to the previous question a list of fraud types was distributed and respondents were asked to assign likeliness of occurrence to each fraud type ('Not at All Likely', 'Likely' and 'Extremely Likely'). Below table shows the likeliness of occurrence of each fraud type according to respondents.

Table 18: Likeliness of occurrence of fraud types

\begin{tabular}{|l|c|c|c|}
\hline \multirow{2}{*}{ Fraud type } & \multicolumn{2}{|c|}{ Likeliness to occur } \\
\cline { 2 - 4 } & $\begin{array}{c}\text { Extremely } \\
\text { likely }\end{array}$ & Likely & $\begin{array}{c}\text { Not at all } \\
\text { likely }\end{array}$ \\
\hline $\begin{array}{l}\text { Invoices received for fictitious goods or } \\
\text { services, inflated invoices }\end{array}$ & 55 & 20 & 14 \\
\hline Kickback/bribe taken by employees & & & \\
\hline Bid rigging & 54 & 21 & 14 \\
\hline $\begin{array}{l}\text { Reimbursement of fictitious or inflated } \\
\text { business expenses by employees }\end{array}$ & 53 & 20 & 16 \\
\hline Misuse of an inventory or an asset of the & 45 & 30 & 20 \\
company & & & 26 \\
\hline Data theft & 39 & 24 & 27 \\
\hline Financial statement fraud & 36 & 26 & 37 \\
\hline Inventory theft & 29 & 23 & 46 \\
\hline Cash theft & 25 & 18 & 54 \\
\hline Falsified working hours & & 23 & \\
\hline Ghost employee & & & \\
\hline
\end{tabular}

Most critical fraud types according to the respondents were receiving invoices for unreal transactions or receiving inflated invoices. This is followed by kickback/bribery and bid rigging. It is seen that most critical fraud types are all related with procurement and purchase processes. 


\subsubsection{Wrongdoings on Behalf of The Company}

Some questions were aimed to understand the likeliness to perform wrongdoings on behalf of the Company.

One of them was that whether the Company permits facilitation payments. Below table shows the number of the Companies accepting facilitation payments.

Table 19: The Companies that permit facilitation payments

\begin{tabular}{|l|c|c|}
\hline $\begin{array}{l}\text { Does your company } \\
\text { permit facilitation } \\
\text { payments? }\end{array}$ & $\begin{array}{c}\text { Number of } \\
\text { respondents }\end{array}$ & $\begin{array}{c}\text { \% of total } \\
\text { number of } \\
\text { respondents }\end{array}$ \\
\hline Yes & 41 & 46.1 \\
\hline No & 26 & 29.2 \\
\hline Do not know & 16 & 18.0 \\
\hline Do not want to answer & 6 & 6.7 \\
\hline
\end{tabular}

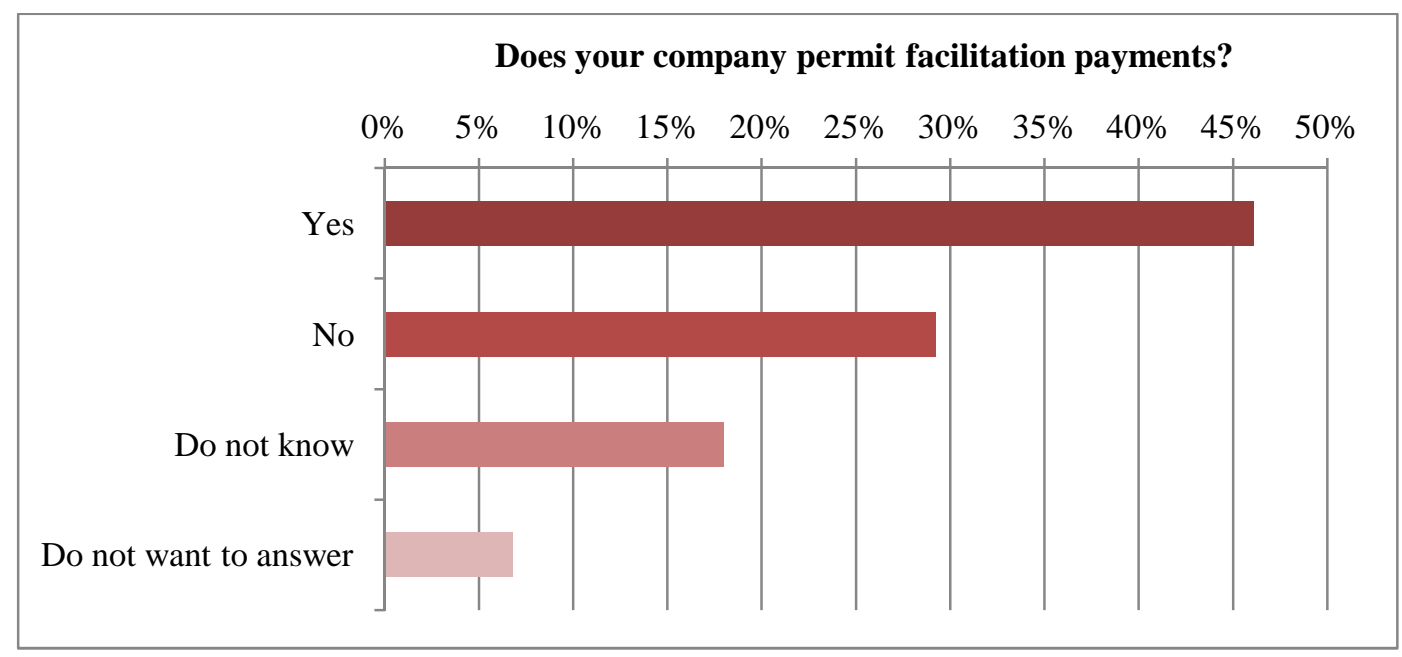

Figure 6: The Companies that permit facilitation payments 
It can be observed that almost $46 \%$ of the Companies accepting facilitation payments. This payment ratio is extremely high when potential consequences of such payments are considered.

Another question was regarding some wrongdoings such as, making payments to employers, giving presents to employers, organization of entertainments for employers or misrepresenting financial status of the company to the market and asking whether these actions can be acceptable during an economic crisis to preserve the present work or gain new businesses. Below table shows the number and portion of the respondents who accept the illegal acts during an economic crisis.

Table 20: Wrongdoings perceived as acceptable during an economic crisis

\begin{tabular}{|l|c|c|c|}
\hline \multirow{2}{*}{ Type of wrongdoing } & \multicolumn{2}{|c|}{ Is it acceptable? } \\
\cline { 2 - 4 } & Yes & No & $\begin{array}{c}\text { Do not want } \\
\text { to answer }\end{array}$ \\
\hline $\begin{array}{l}\text { Giving presents to } \\
\text { employers }\end{array}$ & 27 & 59 & 3 \\
\hline $\begin{array}{l}\text { Organization of } \\
\text { entertainments for } \\
\text { employers }\end{array}$ & 25 & 61 & 3 \\
\hline $\begin{array}{l}\text { Misrepresenting financial } \\
\text { status of the company }\end{array}$ & 24 & 62 & 3 \\
\hline $\begin{array}{l}\text { Making payments to } \\
\text { employers }\end{array}$ & 21 & 65 & 3 \\
\hline
\end{tabular}

Almost $25 \%$ of the respondents stated that making payments to third parties or falsifying financial figures of the Company were acceptable during an economic crisis. Therefore, performing improper acts is acceptable for a considerable 
portion of respondents for the survival of the Company.

\subsubsection{Fraud Prevention Status of the Companies}

Fraud prevention structures of the Companies were analyzed by asking:

- The date of the latest fraud risk assessment,

- Fraud prevention methods of the Company,

- The control methods applied in vendor selection,

- The control methods applied in employee selection.

The first question was the date of latest fraud risk assessment project performed by the Company. Below table shows the dates of latest fraud risk assessment projects and their corresponding percentages.

Table 21: The soonest date of fraud risk assessment on the Companies

\begin{tabular}{|l|c|c|}
\hline $\begin{array}{l}\text { The date of fraud risk } \\
\text { assessment }\end{array}$ & $\begin{array}{c}\text { Number of } \\
\text { Respondents }\end{array}$ & $\begin{array}{c}\text { \% of total } \\
\text { number of } \\
\text { respondents }\end{array}$ \\
\hline Never & 46 & 51.7 \\
\hline Do not know & 29 & 32.6 \\
\hline$<6$ months & 9 & 10.1 \\
\hline 6 months - 1 year & 3 & 3.4 \\
\hline$>1$ year & 2 & 2.2 \\
\hline & 89 & 100.0 \\
\hline
\end{tabular}




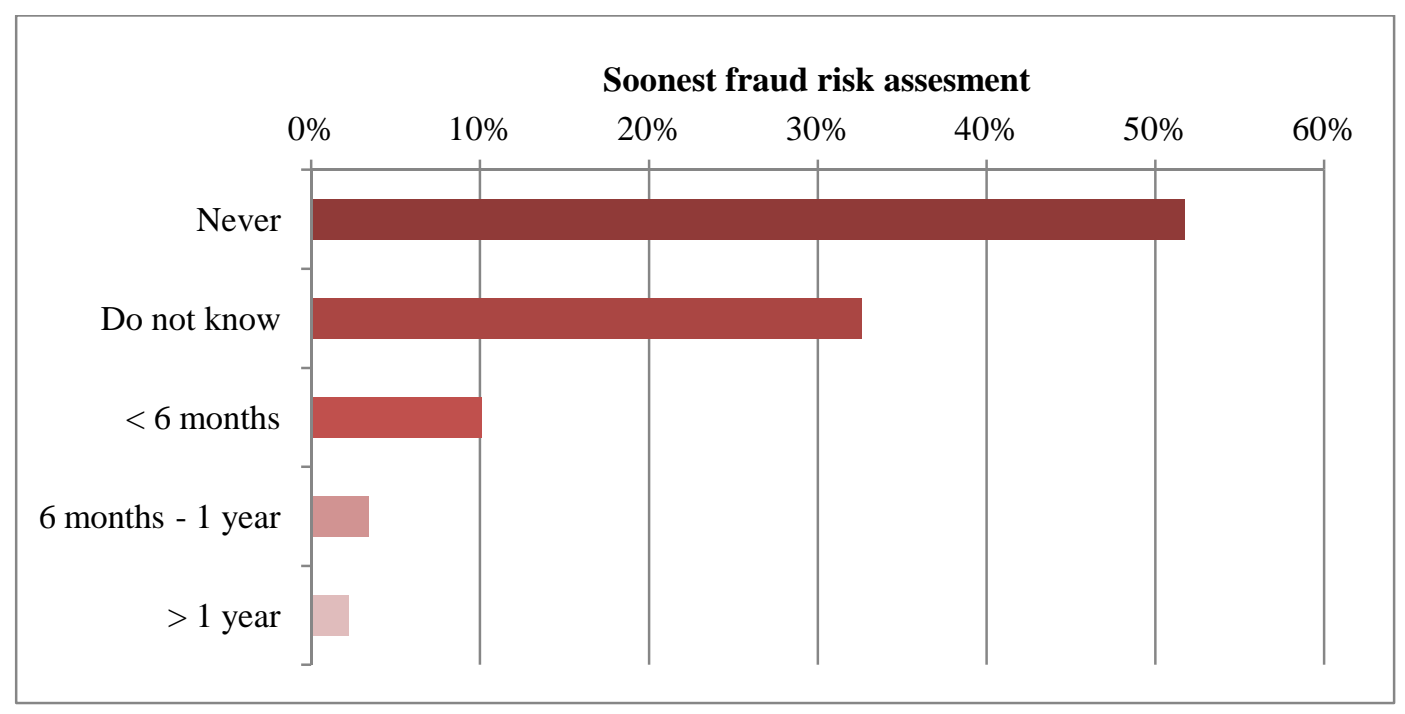

Figure 7: The soonest date of fraud risk assessment on the Companies

Almost 52\% of the Companies have never performed a fraud risk assessment and $33 \%$ of them do not know whether a fraud risk assessment was applied or not. As a result, almost $85 \%$ of the respondents have not experienced a fraud risk assessment, whereas only $15 \%$ of the Companies performed a fraud risk assessment.

Second question was related to the fraud prevention methods used by the Company. Below table illustrates the count of fraud prevention methods used by the Companies. 
Table 22: Fraud prevention methods used by the Companies

\begin{tabular}{|l|c|c|c|}
\hline \multirow{2}{*}{ Fraud prevention method } & \multicolumn{3}{|c|}{ Existence in the Company } \\
\cline { 2 - 4 } & Yes & No & Do not know \\
\hline Internal audit & 59 & 26 & 4 \\
\hline Code of business conducts & 34 & 51 & 4 \\
\hline External audit & 30 & 55 & 4 \\
\hline Legal counsel & 20 & 65 & 4 \\
\hline $\begin{array}{l}\text { Internal trainings (fraud } \\
\text { awareness, ethical rules, } \\
\text { etc.) }\end{array}$ & 15 & 70 & 4 \\
\hline $\begin{array}{l}\text { Periodical legal due } \\
\text { diligence }\end{array}$ & 12 & 73 & 4 \\
\hline Whistle-blowing hotline & 7 & 78 & 4 \\
\hline
\end{tabular}

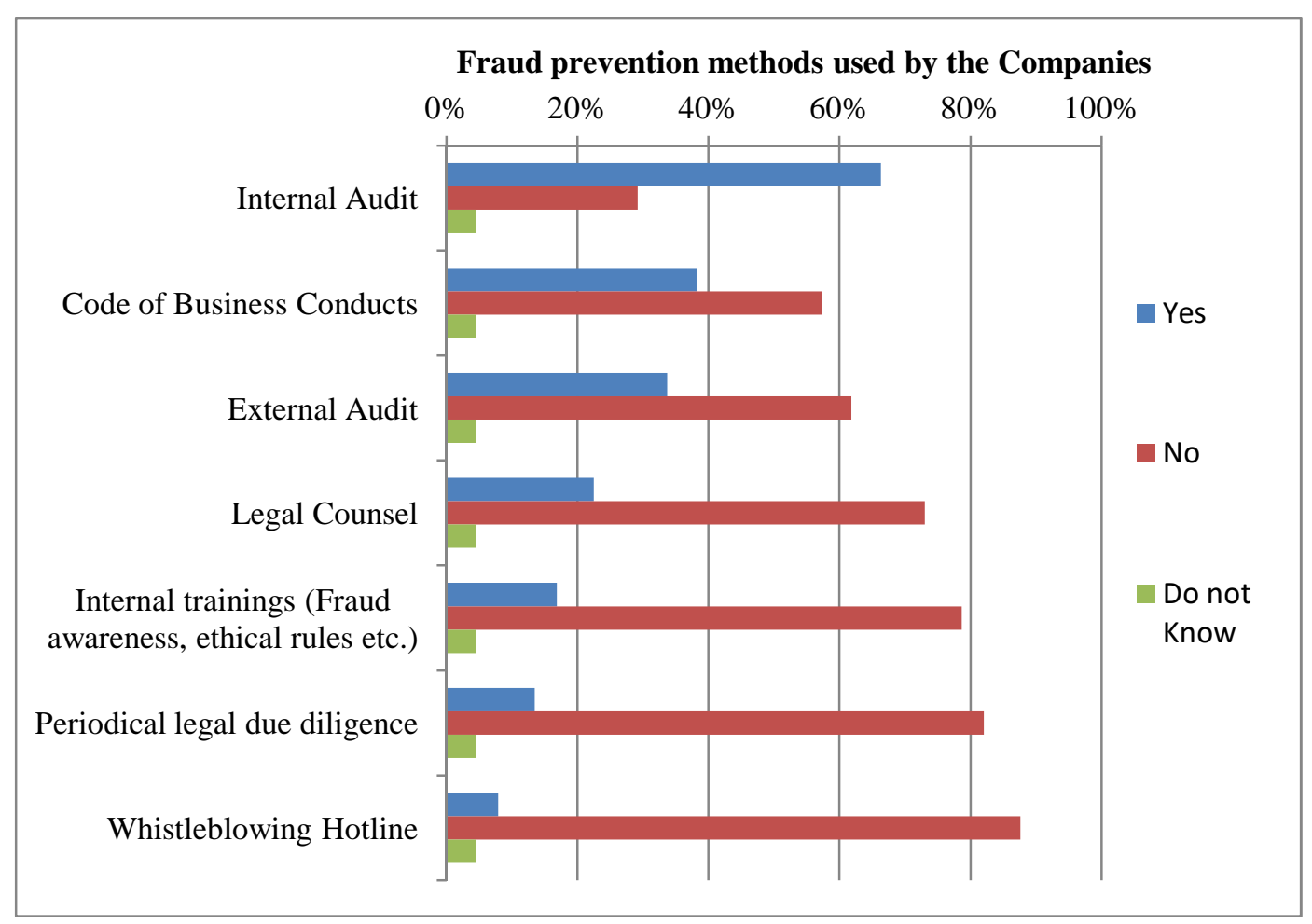

Figure 8: Fraud prevention methods used by the Companies 
Internal audit was the most popular method used by the Companies to prevent fraud. This method was followed by written code of business conducts and external audits, which were used in almost $35 \%$ of the Companies.

Following questions were related to the controls over vendor selection/purchase processes and employee selection. Vendor selection questions were about general controls of the Company such as obtaining bids from multiple vendors, having a list of qualified vendors, etc. Below table shows the controls over vendor selection/purchase process.

Table 23: Controls applied during vendor selection/purchase process

\begin{tabular}{|l|c|c|c|}
\hline \multirow{2}{*}{$\begin{array}{l}\text { Controls applied during } \\
\text { vendor selection }\end{array}$} & \multicolumn{3}{|c|}{ Existence in the company } \\
\cline { 2 - 4 } & 69 & 13 & Do not know \\
\hline $\begin{array}{l}\text { Using different parties for } \\
\text { purchase order and invoice } \\
\text { approval }\end{array}$ & 68 & 16 & 5 \\
\hline $\begin{array}{l}\text { Requirement to obtain bids } \\
\text { from multiple vendors }\end{array}$ & 64 & 18 & 7 \\
\hline $\begin{array}{l}\text { Having a list of } \\
\text { qualified/selected vendors }\end{array}$ & 56 & 29 & 4 \\
\hline $\begin{array}{l}\text { Using different parties for } \\
\text { purchase order and vendor } \\
\text { selection }\end{array}$ & & & \\
\hline $\begin{array}{l}\text { Background checks for } \\
\text { potential vendors }\end{array}$ & 55 & 25 & \\
\hline
\end{tabular}

Almost $60 \%$ of the Companies applied all critical vendor selection/purchase process controls. This ratio is very important considering the high risk of procurement related fraud cases. 
Another question was about the internal controls applied for employee selection by the Company. Below table shows the controls and verifications applied during the employee selection process.

Table 24: Controls applied during employee selection

\begin{tabular}{|l|c|c|c|}
\hline \multirow{2}{*}{$\begin{array}{l}\text { Controls applied during } \\
\text { employee selection }\end{array}$} & Yes & No & Do not know \\
\cline { 2 - 4 } & 53 & 29 & 7 \\
\hline $\begin{array}{l}\text { Past employment } \\
\text { verification }\end{array}$ & 49 & 33 & 7 \\
\hline Reference verification & 39 & 43 & 7 \\
\hline Criminal conviction check & 22 & 60 & 7 \\
\hline $\begin{array}{l}\text { Education and certificate } \\
\text { verification }\end{array}$ & & & \\
\hline
\end{tabular}

More than $50 \%$ of the subject respondents stated that past employment verification was performed in the Companies. It is seen that other employee related checks are below $50 \%$.

\subsubsection{Internal Fraud Cases and Responsive Actions}

In the survey, one of the most critical subjects was the fraud cases experienced by the Companies and their responsive actions. First question was a direct question asking whether the Companies experienced any sort of internal fraud in the last three years. Below table shows the number of the Companies that experienced internal fraud during the specified period. 
Table 25: The Companies experienced internal fraud cases

\begin{tabular}{|l|c|c|}
\hline $\begin{array}{l}\text { The Company } \\
\text { experienced any sort of } \\
\text { internal fraud }\end{array}$ & $\begin{array}{c}\text { Number of } \\
\text { respondents }\end{array}$ & $\begin{array}{c}\text { \% of total } \\
\text { number of } \\
\text { respondents }\end{array}$ \\
\hline Yes & 43 & 48.3 \\
\hline No & 23 & 25.8 \\
\hline Do not know & 15 & 16.9 \\
\hline Do not want to answer & 8 & 9.0 \\
\hline Total & 89 & 100.0 \\
\hline
\end{tabular}

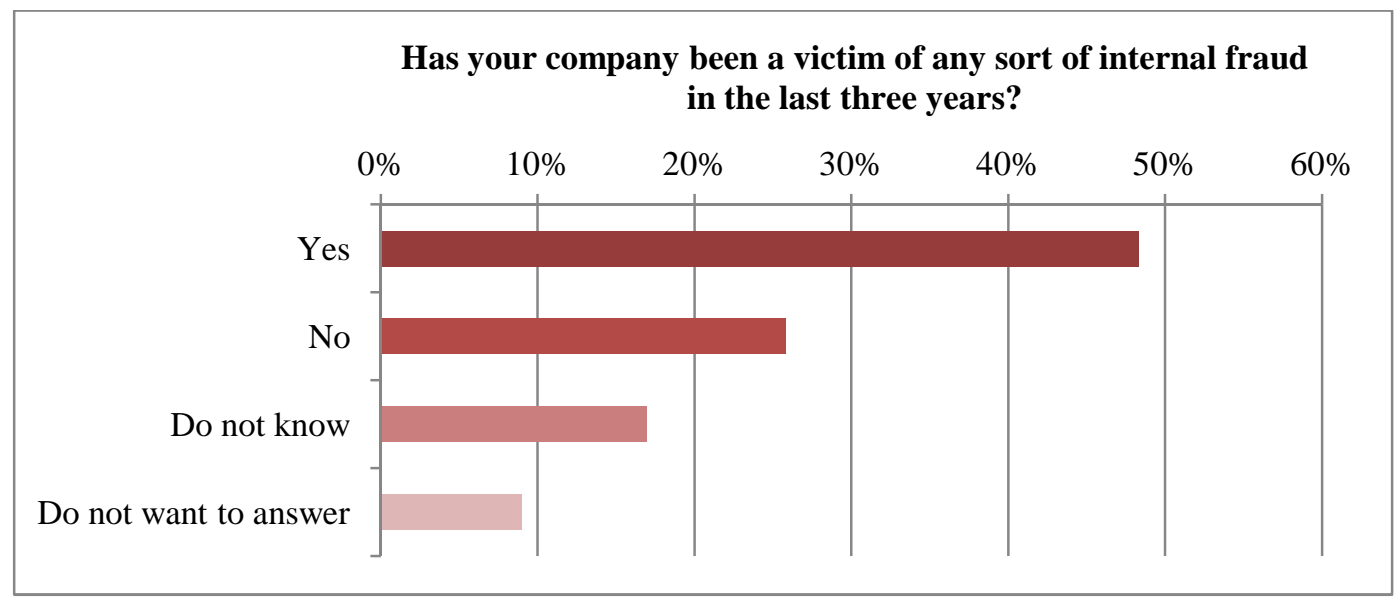

Figure 9: The Companies experienced internal fraud cases

Nearly $50 \%$ of the Companies experienced at least one internal fraud case in the last three years.

Following question was the type of internal fraud experienced within the Company. Below table illustrates the internal fraud type and the number of the Companies experienced this particular fraud type. 
Table 26: Types of fraud cases experienced by the Companies

\begin{tabular}{|l|c|c|c|}
\hline \multirow{2}{*}{ Internal fraud type } & \multicolumn{2}{|c|}{ Experienced by the Company } \\
\cline { 2 - 4 } & Yes & No & $\begin{array}{c}\text { Do not know / } \\
\text { do not want to } \\
\text { answer }\end{array}$ \\
\hline $\begin{array}{l}\text { Invoices received for fictitious goods or } \\
\text { services, inflated invoices }\end{array}$ & 15 & 46 & 28 \\
\hline Reimbursement of fictitious or inflated & & & \\
business expenses by an employee & 15 & 46 & 28 \\
\hline Kickback/bribe taken by employee & & & 28 \\
\hline Cash theft & 14 & 47 & 28 \\
\hline Misuse of an inventory or an asset of the & 14 & 48 & 28 \\
\hline company & 13 & & 28 \\
\hline Inventory theft & & 58 & 28 \\
\hline Data theft & 13 & 50 & 28 \\
\hline Falsified working hours & 11 & 50 & \\
\hline Bid rigging & 11 & 53 & \\
\hline Financial statement fraud & 8 & & \\
\hline Ghost employee & & & 28 \\
\hline
\end{tabular}

28 respondents either stated that they did not know or they preferred not to give a response.

According to the remaining portion of the respondents, receiving inflated invoices or receiving invoices for fictitious materials/services and reimbursement of fictitious business expenses by employees are the two most common type of internal fraud experienced by the Companies. These types of frauds were followed by kickbacks/bribes taken by employees and cash theft.

The last question was about the actions taken by the management after experiencing an internal fraud by the Company. Below table lists actions taken by 
the Companies' managements in response to the fraud cases.

Table 27: Actions of the Companies after experiencing internal fraud cases

\begin{tabular}{|c|c|c|c|}
\hline \multirow{2}{*}{$\begin{array}{l}\text { Actions taken after experiencing internal } \\
\text { fraud }\end{array}$} & \multicolumn{3}{|c|}{ Performed by the Company? } \\
\hline & Yes & No & $\begin{array}{c}\text { Do not know / } \\
\text { Do not want } \\
\text { to answer }\end{array}$ \\
\hline Dismissed the responsible employee & 33 & 39 & 17 \\
\hline Warned the employee & 12 & 60 & 17 \\
\hline $\begin{array}{l}\text { Demanded restitution from the responsible } \\
\text { employee but did not covered the damage }\end{array}$ & 9 & 63 & 17 \\
\hline Nothing & 9 & 63 & 17 \\
\hline Prosecuted the responsible employee & 6 & 66 & 17 \\
\hline $\begin{array}{l}\text { Demanded restitution from the responsible } \\
\text { employee and covered the damage }\end{array}$ & 6 & 66 & 17 \\
\hline
\end{tabular}

Most of the Companies dismissed the employees committed fraud. This action was followed by warning of the responsible employee by the Company.

\subsubsection{Important Results From The Fraud Awareness Survey}

In this section, the critical results of the survey are discussed:

- $43 \%$ of the respondents stated that the Companies are under the risk of fraud.

- $48 \%$ of the Companies experienced an internal fraud case. This result highlights the importance of internal fraud for construction sector.

- $46 \%$ of the respondents stated that the Companies permit facilitation payments. The figure shows that construction companies allow making 
payments to facilitate bureaucratic processes.

- Almost $25 \%$ of the respondents mentioned making illegal payments or falsifying financial statements in order to maintain existing business or to gain new businesses during economic crisis is acceptable. In other words, quarter of the respondents tend to justify inappropriate actions if they think there is a potential risk concerning the existence of their company.

- $52 \%$ of the Companies never performed a fraud risk assessment; half of the companies did not identify the internal fraud risks through a fraud risk assessment process.

- Only $8 \%$ of the Companies had whistle-blowing hotlines, $17 \%$ of the Companies perform internal trainings to prevent fraud and $38 \%$ of the Companies had a code of business conduct. These results show that most Companies did not have fraud prevention measures in place.

- Only $62 \%$ of the Companies performed background checks for potential vendors.

- Nearly half of the Companies did not perform background checks for their employees. 


\section{CHAPTER 5}

\section{STATISTICAL ANALYSES OF THE FRAUD SURVEY}

Some statistical tests are used in order to reveal the relationships between the variables. Fraud survey questionnaire consists mostly of qualitative variables and some quantitative variables. Thus, statistical tests which fit for categorical data are used to understand whether there is any association between variables or not. In case of observation of any association, degrees of associations are also analyzed.

In statistical testing, two different testing methods are applied. One of them is Chi-square test which is used to understand whether there is any association between two variables. In case of observation of a relationship between variables, Kendall-tau Test is used to determine the strength of the relation.

Most of the statistical tests are calculated manually; however, in some complex calculations SPSS (Statistical Package for Social Sciences) 17 software is used.

\subsection{Chi-square test}

Chi-square $\left(\chi^{2}\right)$ test is also known as Pearson's Chi-square test. Pearson's Chisquare test (Chernoff and Lehmann, 1954) is used to assess two types of comparisons: tests of goodness of fit and tests of independence. Test of goodness of fit is used to understand whether an observed frequency distribution differs from a theoretical distribution. Test of independence assesses whether paired observations on two variables, expressed in a contingency table (Table 28), are independent of each other. 
In this study, the Chi-square test of independence is used, since the aim of this study is to understand associations between variables rather than goodness of fit.

While applying Chi-square independence test, following steps are followed:

1) Null hypothesis $\left(\mathrm{H}_{0}\right)$ is proposed. $\mathrm{H}_{0}$ states that there is no significant association between the variables.

2) Contingency Table (Table 28) is prepared to record and analyze the relation between two or more categorical variables.

Contingency table displays frequency distribution of the variables in a matrix format. In the matrix, observed values (OV) and expected values $(\mathrm{EV})$ are recorded in the corresponding rows and columns.

Table 28: Contingency table

\begin{tabular}{|l|c|c|c|c|}
\hline & \multicolumn{4}{|c|}{ I. Variable } \\
\hline II. Variable & 1 (Observed Value) & 1 (Expected Value) & 2 (Observed Val.) & 2 (Expected Val.) \\
\hline 1 & $\mathrm{~N}_{11}$ & $\mathrm{~N}_{11}$ & $\mathrm{~N}_{12}$ & $\mathrm{~N}_{12}$ \\
\hline 2 & $\mathrm{~N}_{21}$ & $\mathrm{~N}_{21}$ & $\mathrm{~N}_{22}$ & $\mathrm{~N}_{22}$ \\
\hline
\end{tabular}

3) Significance level $(\alpha)$ is determined.

4) Degree of Freedom (DF) is determined. DF is equal to (r-1) $x(c-1)$ in which $\mathrm{r}$ is the number of rows and $\mathrm{c}$ is the number of columns.

$\mathrm{DF}=(\mathrm{r}-1) \times(\mathrm{c}-1)$ 
5) $\mathrm{H}_{0}$ rejection area is determined. By using the level of significance $(\alpha)$, DF, critical value (Table 29) $\left(\chi^{2} \mathrm{c}\right)$ is determined. If $\chi^{2}>\chi^{2} \mathrm{c}, \mathrm{H}_{0}$ hypothesis will be rejected.

6) $\chi^{2}$ value is calculated by using the contingency table and the below formula:

$$
\chi^{2}=\sum_{i=1}^{r} \sum_{j=1}^{c} \frac{\left(O V_{i j}-E V_{i j}\right)^{2}}{E V_{i j}}
$$

Expected value of each cell on the contingency table is calculated by multiplying corresponding sum of row and sum of column divided by the grand total.

Expected value $(\mathrm{EV})=\frac{\text { Sum of row }(r) x \operatorname{Sum} \text { of column }(c)}{\text { Grand Total }}$ 
Table 29: Critical values of the $\chi^{2}\left(\chi^{2} c\right)$ distribution

\begin{tabular}{|c|c|c|c|c|c|c|}
\hline & \multicolumn{6}{|c|}{ Area in the upper tail } \\
\hline DF & 0.99 & 0.95 & 0.90 & 0.10 & 0.05 & 0.01 \\
\hline $\mathbf{1}$ & 0.000 & 0.004 & 0.016 & 2.706 & 3.841 & 6.635 \\
\hline $\mathbf{2}$ & 0.020 & 0.103 & 0.211 & 4.605 & 5.991 & 9.210 \\
\hline $\mathbf{3}$ & 0.115 & 0.352 & 0.584 & 6.251 & 7.815 & 11.345 \\
\hline $\mathbf{4}$ & 0.297 & 0.711 & 1.064 & 7.779 & 9.488 & 13.277 \\
\hline $\mathbf{5}$ & 0.554 & 1.145 & 1.610 & 9.236 & 11.070 & 15.086 \\
\hline $\mathbf{6}$ & 0.872 & 1.635 & 2.204 & 10.645 & 12.592 & 16.812 \\
\hline $\mathbf{7}$ & 1.239 & 2.167 & 2.833 & 12.017 & 14.067 & 18.475 \\
\hline $\mathbf{8}$ & 1.646 & 2.733 & 3.490 & 13.362 & 15.507 & 20.090 \\
\hline $\mathbf{9}$ & 2.088 & 3.325 & 4.168 & 14.684 & 16.919 & 21.666 \\
\hline $\mathbf{1 0}$ & 2.558 & 3.940 & 4.865 & 15.987 & 18.307 & 23.209 \\
\hline $\mathbf{1 1}$ & 3.053 & 4.575 & 5.578 & 17.275 & 19.675 & 24.725 \\
\hline $\mathbf{1 2}$ & 3.571 & 5.226 & 6.304 & 18.549 & 21.026 & 26.217 \\
\hline $\mathbf{1 3}$ & 4.107 & 5.892 & 7.042 & 19.812 & 22.362 & 27.688 \\
\hline $\mathbf{1 4}$ & 4.660 & 6.571 & 7.790 & 21.064 & 23.685 & 29.141 \\
\hline $\mathbf{1 5}$ & 5.229 & 7.261 & 8.547 & 22.307 & 24.996 & 30.578 \\
\hline
\end{tabular}

On the other hand, for 2X2 tables Fisher's exact test is applied by using SPSS 17 software. This test is used for the analysis of contingency tables which has small sizes of samples, mostly for $2 \mathrm{X} 2$ tables. Fisher's exact test is accepted as an exact test due to its ability to calculate the significance of the deviation from the null hypothesis exactly. For larger samples, significance values based on Pearson's goodness-of-fit test and Fisher's exact test are almost identical.

\subsection{Kendall-tau Coefficients}

There are several methods to determine associations between two variables. Calculation of Kendall's tau $(\tau)$ coefficient is one of the methods in which the coefficient represents the rank correlation between two measured quantities. 
Three different types of Kendall-tau coefficients exist: Kendall-tau-a, Kendall-tau$\mathrm{b}$ and Kendall-tau-c. In this study Kendall-tau-b for square tables and Kendall-tauc for rectangular tables were used while calculating the strength of association of the cross tabulations when both variables are measured at the ordinal level. Kendall-tau-a was not used as it does not make any adjustment for ties.

In Kendall-tau tests, coefficient values range from -1 to +1 , where -1 means complete negative association and +1 means complete positive association (Kruskal, 1958).

The formula of tau-b and tau-c were shown below.

$$
\begin{aligned}
& \text { Tau }-b=\frac{P-Q}{\sqrt{(P+Q+T x)(P+Q+T y)}} \\
& \text { Tau }-c=\frac{2 m(P-Q)}{n^{2}(m-1)}
\end{aligned}
$$

Where;

P: Number of concordant parts

Q: Number of discordant parts

Tx: Number of pairs tied on $X$ but not on $Y$

Ty: Number of pairs tied on Y but not on $\mathrm{X}$

$\mathrm{m}$ : Number of rows or columns whichever is smallest

$\mathrm{n}$ : Total number of cases

In this study, most of the data is not ordinal; however, in order to apply Kendall tests, the data is classified with ordinal numbers. 


\subsection{Testing the Relationships between Variables}

By using the SPSS 17 software, all of the potential associations between variables are tested. In the following sections, only some important associations are discussed. In the first test, calculation methods of the values, which are used in the tests, are demonstrated however in other tests only summary tables are used.

First analysis is about the relationship between the respondents working for a company that made construction projects abroad and the perception of those respondents on the importance level of the periodic management reviews to prevent fraud.

$\mathrm{EV}$ is the first value to be calculated by using Formula 5. For instance, EV of $\mathrm{N}_{11}$ is calculated by performing the following steps:

1) Multiply summation of row (1), 58, with summation of column (1), which is 15 . The result is 870 .

2) Divide the result, 870 , by grand total, 89 , which is summation of all observed values (in this case, it is the number of respondents). Based on this calculation, $\mathrm{EV}$ of $\mathrm{N}_{11}$ is 9.775 .

In order to determine the EVs of other cells, similar steps need to be performed.

Below table is obtained after calculating the EV of each cell. 
Table 30: Contingency table of the Companies performed construction projects abroad vs. importance level of management reviews according to respondents

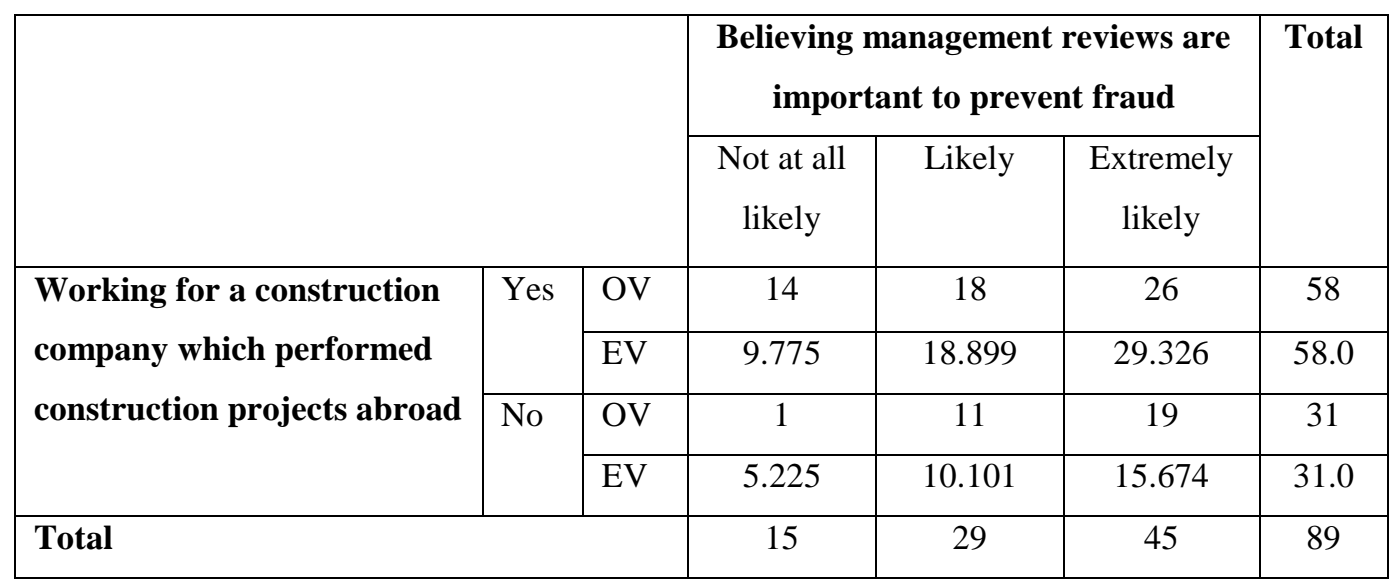

The above table is a $3 \times 2$ table and $0 \%(0 / 6)$ of $\mathrm{EV}$ is lower than 5; as a result, Pearson Chi-square test can be applied.

Chi-square value is the sum of Chi-square values of each cell. With the help of the formula 5, all corresponding values can be calculated. Calculation of Chi-square value for this particular case is shown below:

$\chi^{2}=(9.775-14)^{2} / 9.775+(18.899-18)^{2} / 18.899+(29.326-26)^{2} / 29.326+(5.225-$ $1)^{2} / 5.225+(10.101-11)^{2} / 10.101+(15.674-19)^{2} / 15.674=6.448$

After calculating the chi square value, the hypothesis is offered:

$\mathbf{H}_{\mathbf{0}}$ : There is no significant association between working for a construction company which performed projects abroad and believing that management reviews are important to prevent fraud

Chi-square Value $=6.448$

Degree of Freedom $=(3-1) \times(2-1)=3$

Significance Level $=0.05$ (chosen) 
Critical value $\left(\chi^{2} \mathbf{c}\right)=5.911$ (found from Table 29)

$\chi^{2}<\chi^{2} \mathrm{c}$ so there is enough evidence to reject $\mathrm{H}_{0}$ hypothesis on 0.05 significance level. Therefore, there is a relationship between working for a company making construction projects abroad and believing that management reviews are important to prevent fraud.

In order to calculate the strength of the relationship, Kendall tests were applied.

Firstly, importance level of management review to prevent fraud (according to respondent) is categorized into 3 groups in which 'Not at all likely' is numbered 1, 'Likely' is numbered 2 and 'Extremely Likely' is numbered 3. Secondly, the Company carried construction projects abroad in the last three years is grouped in 2 categories in which 'Yes' is numbered 1 and 'No' is numbered 2. Observed values are shown on rectangular cross table below:

Table 31: Cross tabular of the Companies performed construction projects abroad vs. importance level of management reviews according to respondents

\begin{tabular}{|c|c|c|c|c|c|}
\hline & \multicolumn{3}{|c|}{$\begin{array}{c}\text { Importance level of management } \\
\text { review to prevent fraud } \\
\text { according to respondent }\end{array}$} & \multirow[t]{2}{*}{ Total } \\
\hline & & 1 & 2 & 3 & \\
\hline \multirow{2}{*}{$\begin{array}{l}\text { Working for a construction company } \\
\text { which performed construction } \\
\text { projects abroad }\end{array}$} & 1 & 14 & 18 & 26 & 58 \\
\hline & 2 & 1 & 11 & 19 & 31 \\
\hline \multicolumn{2}{|l|}{ Total } & 15 & 29 & 45 & 89 \\
\hline
\end{tabular}

In order to calculate Kendall-tau-b and Kendall-tau-c coefficients, below values are calculated: 
$P($ Number of concordant parts $)=14 \times(11+19)+18 \times 19=762$

$\mathrm{Q}($ Number of discordant parts $)=1 \times(18+26)+11 \times 26=330$

$\mathrm{Tx}($ Number of pairs tied only on $\mathrm{X})=(14 \mathrm{x} 1)+(18 \mathrm{x} 11)+(26 \mathrm{X} 19)=706$

Ty $($ Number of pairs tied only on $Y)=(14 \times 18)+(14 \times 26)+(18 \times 26)+(1 \times 11)+$ $(1 \times 19)+(11 \times 19)=1323$

$\mathrm{m}$ (Number of rows or columns whichever is smallest $)=2$

$\mathrm{n}($ Total number of cases $)=89$

$\operatorname{Tau}-b=\frac{762-330}{\sqrt{(762+330+706)(762+330+1323)}}=0,207$

$\operatorname{Tau}-c=\frac{2 \times 2(762-330)}{89^{2}(2-1)}=0,218$

Kendall coefficients and significance levels of these coefficients were also calculated and verified by using SPSS 17 software. Below table shows the Kendall-tau coefficients and their significance levels. In the table, asymptotic standard error illustrates the error rate between Kendall value and Approximately $\mathrm{T}$ which is the $\mathrm{t}$ distribution with approximate significance.

Table 32: Kendall-tau tests for the Companies performed construction projects abroad vs. importance level of management reviews according to respondents

\begin{tabular}{|l|c|c|c|c|}
\hline & Value & Asymp. Std. Error & Approx. T $^{\mathbf{b}}$ & Approx. Sig. \\
\hline Kendall's tau-b & 0.207 & 0.090 & 2.253 & 0.024 \\
\hline Kendall's tau-c & 0.218 & 0.097 & 2.253 & 0.024 \\
\hline \# of valid cases & 89 & & & \\
\hline
\end{tabular}

a. Not assuming the null hypothesis

b. Using the asymptotic standard error assuming the null hypothesis 
Kendall-tau-c coefficient is used since the contingency table is rectangular. Significance level of Kendall-tau-c coefficient is 0.024 and it is less than the significance level of 0.05 . Therefore, there is enough evidence to reject $\mathrm{H}_{0}$ on the 0.05 significance level and a positive association between variables is identified.

Result of the analysis showed that respondents, who worked for construction companies doing business abroad, believe in the importance of management reviews more.

Below table shows other correlation analyses performed between the variables and expected associations between the variables.

Table 33: The variables and expected associations

\begin{tabular}{|l|l|l|l|}
\hline No & Independent variable & $\begin{array}{l}\text { Dependent } \\
\text { variable }\end{array}$ & Expected association \\
\hline $\mathbf{1}$ & Performing projects & $\begin{array}{l}\text { Thinking the } \\
\text { Company is under } \\
\text { the risk of fraud }\end{array}$ & $\begin{array}{l}\text { The employees, who are working for } \\
\text { companies performing projects abroad, are } \\
\text { more likely to think that the Company is } \\
\text { under the risk of fraud due to diversified } \\
\text { structure of the Company }\end{array}$ \\
\hline $\mathbf{2}$ & Annual revenue & $\begin{array}{l}\text { Having code of } \\
\text { business conduct }\end{array}$ & $\begin{array}{l}\text { The Companies which have higher } \\
\text { revenues are more likely to have code of } \\
\text { business conduct }\end{array}$ \\
\hline $\mathbf{3}$ & Number of employees & $\begin{array}{l}\text { Having code of } \\
\text { business conduct }\end{array}$ & $\begin{array}{l}\text { The Companies which have higher } \\
\text { number of employees are more likely to } \\
\text { have code of business conduct }\end{array}$ \\
\hline $\mathbf{4}$ & Number of employees & $\begin{array}{l}\text { Getting external } \\
\text { audit services }\end{array}$ & $\begin{array}{l}\text { The Companies which have higher } \\
\text { number of employees are more likely to } \\
\text { get external audit services }\end{array}$ \\
\hline
\end{tabular}


Table 33: The variables and expected associations (continued)

\begin{tabular}{|c|c|c|c|}
\hline 5 & Annual revenue & $\begin{array}{l}\text { Having an internal } \\
\text { audit function }\end{array}$ & $\begin{array}{l}\text { The Companies which have higher } \\
\text { revenues are more likely to have internal } \\
\text { audit function }\end{array}$ \\
\hline 6 & Number of employees & $\begin{array}{l}\text { Having a list of } \\
\text { qualified/selected } \\
\text { vendors }\end{array}$ & $\begin{array}{l}\text { The Companies which have higher } \\
\text { number of employees are more likely to } \\
\text { have a list of qualified/selected vendors }\end{array}$ \\
\hline 7 & Annual revenue & $\begin{array}{l}\text { Having a list of } \\
\text { qualified/selected } \\
\text { vendors }\end{array}$ & $\begin{array}{l}\text { The Companies which have higher } \\
\text { revenues are more likely to have a list of } \\
\text { qualified/selected vendors }\end{array}$ \\
\hline 8 & Annual revenue & $\begin{array}{l}\text { Having } \\
\text { requirement to } \\
\text { obtain bids from } \\
\text { multiple vendors }\end{array}$ & $\begin{array}{l}\text { The Companies which have higher } \\
\text { revenues are more likely to have } \\
\text { requirement to obtain bids from multiple } \\
\text { vendors }\end{array}$ \\
\hline 9 & Number of employees & $\begin{array}{l}\text { Having segregated } \\
\text { purchase order and } \\
\text { vendor selection } \\
\text { functions }\end{array}$ & $\begin{array}{l}\text { The Companies which have higher } \\
\text { number of employees are more likely to } \\
\text { have segregated purchase order and } \\
\text { vendor selection functions }\end{array}$ \\
\hline 10 & Number of employees & $\begin{array}{l}\text { Verifying } \\
\text { education and } \\
\text { certificate } \\
\text { information of job } \\
\text { applicants }\end{array}$ & $\begin{array}{l}\text { The Companies which have higher } \\
\text { number of employees are more likely to } \\
\text { verify education and certificate } \\
\text { information of job applicants }\end{array}$ \\
\hline 11 & $\begin{array}{l}\text { Internal Fraud } \\
\text { Occurred }\end{array}$ & $\begin{array}{l}\text { Thinking the } \\
\text { Company is under } \\
\text { the risk of fraud }\end{array}$ & $\begin{array}{l}\text { The employees, who witness fraud } \\
\text { incidents, are more likely to think that the } \\
\text { Company is under the risk of fraud }\end{array}$ \\
\hline 12 & Annual revenue & $\begin{array}{l}\text { Internal Fraud } \\
\text { Occurred }\end{array}$ & $\begin{array}{l}\text { The Companies which have higher } \\
\text { revenues are more likely to experience } \\
\text { internal fraud }\end{array}$ \\
\hline 13 & $\begin{array}{l}\text { Number of expertise } \\
\text { areas }\end{array}$ & $\begin{array}{l}\text { Internal Fraud } \\
\text { Occurred }\end{array}$ & $\begin{array}{l}\text { The Companies which have higher } \\
\text { number of expertise areas more likely to } \\
\text { experience internal fraud }\end{array}$ \\
\hline 14 & $\begin{array}{l}\text { Performing projects } \\
\text { abroad }\end{array}$ & $\begin{array}{l}\text { Internal Fraud } \\
\text { Occurred }\end{array}$ & $\begin{array}{l}\text { The Companies which perform projects } \\
\text { abroad are more likely to experience } \\
\text { internal fraud }\end{array}$ \\
\hline
\end{tabular}


Table 33: The variables and expected associations (continued)

\begin{tabular}{|c|c|c|c|}
\hline 15 & $\begin{array}{l}\text { Having an internal } \\
\text { audit function }\end{array}$ & $\begin{array}{l}\text { Internal Fraud } \\
\text { Occurred }\end{array}$ & $\begin{array}{l}\text { The Companies which have internal audit } \\
\text { function are less likely to experience } \\
\text { internal fraud }\end{array}$ \\
\hline 16 & $\begin{array}{l}\text { Checking the } \\
\text { references of job } \\
\text { applicants }\end{array}$ & $\begin{array}{l}\text { Internal Fraud } \\
\text { Occurred }\end{array}$ & $\begin{array}{l}\text { The Companies which check the } \\
\text { references of job applicants are less likely } \\
\text { to experience internal fraud }\end{array}$ \\
\hline 17 & $\begin{array}{l}\text { Permitting/encouraging } \\
\text { facilitation payments }\end{array}$ & $\begin{array}{l}\text { Internal Fraud } \\
\text { Occurred }\end{array}$ & $\begin{array}{l}\text { The Companies which permit/encourage } \\
\text { facilitation payments are more likely to } \\
\text { experience internal fraud }\end{array}$ \\
\hline 18 & $\begin{array}{l}\text { Thinking "organizing } \\
\text { entertainments for } \\
\text { employers is } \\
\text { acceptable for the } \\
\text { survival of the } \\
\text { Company" }\end{array}$ & $\begin{array}{l}\text { Internal Fraud } \\
\text { Occurred }\end{array}$ & $\begin{array}{l}\text { The Companies which have employees } \\
\text { thinking "organizing entertainments for } \\
\text { employers are acceptable for the survival } \\
\text { of the Company" are more likely to } \\
\text { experience internal fraud }\end{array}$ \\
\hline 19 & $\begin{array}{l}\text { Thinking "giving } \\
\text { presents to employers } \\
\text { is acceptable for the } \\
\text { survival of the } \\
\text { Company" }\end{array}$ & $\begin{array}{l}\text { Internal Fraud } \\
\text { Occurred }\end{array}$ & $\begin{array}{l}\text { The Companies which have employees } \\
\text { thinking "giving presents to employers are } \\
\text { acceptable for the survival of the } \\
\text { Company" are more likely to experience } \\
\text { internal fraud }\end{array}$ \\
\hline 20 & $\begin{array}{l}\text { Thinking "bribing } \\
\text { employers is } \\
\text { acceptable for the } \\
\text { survival of the } \\
\text { Company" }\end{array}$ & $\begin{array}{l}\text { Internal Fraud } \\
\text { Occurred }\end{array}$ & $\begin{array}{l}\text { The Companies which have employees } \\
\text { thinking "bribing employers is acceptable } \\
\text { for the survival of the Company" are more } \\
\text { likely to experience internal fraud }\end{array}$ \\
\hline 21 & $\begin{array}{l}\text { Permitting/encouraging } \\
\text { facilitation payments }\end{array}$ & $\begin{array}{l}\text { Internal Fraud, } \\
\text { "misuse of } \\
\text { inventory" } \\
\text { occurred }\end{array}$ & $\begin{array}{l}\text { The Companies which permit/encourage } \\
\text { facilitation payments are more likely to } \\
\text { experience misuse of inventory }\end{array}$ \\
\hline 22 & $\begin{array}{l}\text { Permitting/encouraging } \\
\text { facilitation payments }\end{array}$ & $\begin{array}{l}\text { Internal Fraud, } \\
\text { "cash theft" } \\
\text { occurred }\end{array}$ & $\begin{array}{l}\text { The Companies which permit/encourage } \\
\text { facilitation payments are more likely to } \\
\text { experience cash theft }\end{array}$ \\
\hline
\end{tabular}




\section{Correlation Analysis 1}

$\mathbf{H}_{\mathbf{0}}$ : There is no significant association between working for a construction company that performed construction projects abroad and believing it is under the risk of internal fraud.

Table 34: Contingency table of performing projects abroad and thinking that the Company is under fraud risk

\begin{tabular}{|c|c|c|c|c|c|}
\hline & \multicolumn{2}{|c|}{$\begin{array}{l}\text { Do you think that your } \\
\text { company under the risk of } \\
\text { internal fraud? }\end{array}$} & \multirow[t]{2}{*}{ Total } \\
\hline & & & Yes (1) & No (2) & \\
\hline \multirow{4}{*}{$\begin{array}{l}\text { Does your company } \\
\text { performed construction } \\
\text { projects abroad in the last } \\
\text { three years? }\end{array}$} & Yes & $\mathrm{OV}$ & 29 & 29 & \multirow{2}{*}{58} \\
\hline & (1) & EV & 24.8 & 33.2 & \\
\hline & No & $\mathrm{OV}$ & 9 & 22 & \multirow{2}{*}{31} \\
\hline & (2) & EV & 13.2 & 17.8 & \\
\hline \multicolumn{3}{|l|}{ Total } & 38 & 61 & 89 \\
\hline
\end{tabular}

Table 35: Chi Square tests for correlation between performing projects abroad and thinking that the Company is under fraud risk

\begin{tabular}{|l|c|c|c|c|c|}
\hline & Value & DF & $\begin{array}{c}\text { Asymp. Sig. } \\
(\mathbf{2} \text {-sided })\end{array}$ & $\begin{array}{c}\text { Exact Sig. } \\
\text { (2-sided) }\end{array}$ & $\begin{array}{c}\text { Exact Sig. } \\
\text { (1-sided) }\end{array}$ \\
\hline Pearson Chi-Square & $3.630^{\mathrm{a}}$ & 1 & 0.057 & & \\
\hline Continuity Correction & & & & \\
\hline Likelihood Ratio & 2.824 & 1 & 0.093 & & \\
\hline Fisher's Exact Test & 3.718 & 1 & 0.054 & & 0.045 \\
\hline Linear-by-Linear Association & 3.589 & 1 & 0.058 & & \\
\hline \# of valid cases & 89 & & & & \\
\hline
\end{tabular}

a. 0 cells $(0.0 \%)$ have expected count less than 5 . The minimum expected count is 13.24.

b. Computed only for a $2 \times 2$ table 
Significance Level (observed) $=0.073$ (Fisher's exact test) $($ Table 35)

Significance Level $($ chosen $)=0.05$

Significance level of Fisher's exact test is 0.073 which is more than the chosen level of 0.05 , however it is less than 0.1 . Therefore, there is enough evidence to reject $\mathrm{H}_{0}$ on the 0.1 significance level. As a result, there is an association between working for a company which have construction projects abroad and the thinking that the Company is under the risk of internal fraud.

In order to identify the degree of association between the variables, Kendall-tau tests are applied. Below table shows the results of Kendall-tau tests.

Table 36: Kendall-tau tests for association between performing projects abroad and thinking that the Company is under fraud risk

\begin{tabular}{|c|c|c|c|c|}
\hline & Value & Asymp. Std. Error ${ }^{a}$ & Approx. $\mathbf{T}^{\mathrm{b}}$ & Approx. Sig. \\
\hline Kendall's tau-b & 0.202 & 0.101 & 1.985 & 0.047 \\
\hline Kendall's tau-c & 0.190 & 0.096 & 1.985 & 0.047 \\
\hline \# of valid cases & 89 & & & \\
\hline
\end{tabular}

In this case, Kendall-tau-b coefficient is used since the contingency table is $2 \mathrm{X} 2$ square. Kendall-tau-b coefficient is 0.202 and the significance level of Kendalltau-b coefficient is 0.047 which is less than the significance level of 0.05 . Therefore, on the 0.05 significance level there is a positive association between the variables.

$\underline{\text { Result 1: }}$ 
Respondents working for construction companies which perform projects abroad think that their company is under the risk of fraud.

\section{Correlation Analysis 2}

$\mathbf{H}_{\mathbf{0}}$ : There is no significant association between annual revenue of a company and having code of business conduct.

Table 37: Contingency table of the annual revenue of the Company and having code of business conduct

\begin{tabular}{|c|c|c|c|c|c|}
\hline & \multicolumn{2}{|c|}{$\begin{array}{l}\text { Does your company have } \\
\text { code of business conduct? }\end{array}$} & \multirow[t]{2}{*}{ Total } \\
\hline & & & Yes (1) & No (2) & \\
\hline \multirow{6}{*}{$\begin{array}{l}\text { What is the annual } \\
\text { revenue of the } \\
\text { company? }\end{array}$} & \multirow{2}{*}{$\begin{array}{l}<15 \mathrm{M} \\
\text { (1) }\end{array}$} & $\mathrm{OV}$ & 7 & 25 & \multirow{2}{*}{32} \\
\hline & & EV & 12.8 & 19.2 & \\
\hline & \multirow{2}{*}{$\begin{array}{l}15 M-100 M \\
(2)\end{array}$} & $\mathrm{OV}$ & 6 & 10 & \multirow{2}{*}{16} \\
\hline & & EV & 6.4 & 9.6 & \\
\hline & \multirow{2}{*}{$\begin{array}{l}>100 \mathrm{M} \\
\text { (3) }\end{array}$} & $\mathrm{OV}$ & 21 & 16 & \multirow{2}{*}{37} \\
\hline & & EV & 14.8 & 22.2 & \\
\hline \multicolumn{3}{|l|}{ Total } & 34 & 51 & 85 \\
\hline
\end{tabular}

Table 38: Chi Square tests for correlation between the annual revenue of the Company and having code of business conduct

\begin{tabular}{|c|c|c|c|}
\hline & Value & DF & Asymp. Sig. (2-sided) \\
\hline Pearson Chi-Square & $8.751^{\mathrm{a}}$ & 2 & 0.013 \\
\hline Likelihood Ratio & 9.006 & 2 & 0.011 \\
\hline Linear-by-Linear Association & 8.630 & 1 & 0.003 \\
\hline$\#$ of valid cases & 85 & & \\
\hline
\end{tabular}


Significance Level $($ observed $)=0.013($ Pearson Chi Square $)($ Table 38)

Significance Level $($ chosen $)=0.05$

Significance level of Pearson's Chi-square test is 0.013 which is less than the chosen level of 0.05 . Therefore, there is enough evidence to reject $\mathrm{H}_{0}$ on the 0.05 significance level. It means that there is an association between annual revenue of the Company and having code of business conduct for construction companies.

In order to identify the degree of association between variables, Kendall-tau tests are applied. Below table shows the results of Kendall-tau tests.

Table 39: Kendall-tau tests for the annual revenue of the Company and having code of business conduct

\begin{tabular}{|c|c|c|c|c|}
\hline & Value & Asymp. Std. Error ${ }^{a}$ & Approx. $\mathbf{T}^{\mathrm{b}}$ & Approx. Sig. \\
\hline Kendall's tau-b & -0.305 & 0.095 & -3.177 & 0.001 \\
\hline Kendall's tau-c & -0.336 & 0.106 & -3.177 & 0.001 \\
\hline \# of valid cases & 85 & & & \\
\hline
\end{tabular}

In this case, Kendall-tau-c coefficient is used since the contingency table is rectangular. Kendall-tau-c coefficient is -0.336 and the significance level of Kendall-tau-c coefficient is 0.001 which is less than the significance level of 0.05 . Therefore, on the 0.05 significance level, there is a negative association between variables.

\section{Result 2:}

The higher the company revenue, the more likely is that the company has code of business conduct. 


\section{Correlation Analysis 3}

$\mathbf{H}_{\mathbf{0}}$ : There is no significant association between the number of employees of a company and having a code of business conduct.

Table 40: Contingency table of the number of employees and having code of business conduct

\begin{tabular}{|c|c|c|c|c|c|}
\hline & \multicolumn{2}{|c|}{$\begin{array}{c}\text { Does your company } \\
\text { have code of business } \\
\text { conduct? }\end{array}$} & \multirow[t]{2}{*}{ Total } \\
\hline & & & Yes (1) & No (2) & \\
\hline \multirow{6}{*}{$\begin{array}{l}\text { What Is The Number of } \\
\text { Employees Working At } \\
\text { The Central Office of } \\
\text { Your Company? }\end{array}$} & \multirow{2}{*}{$\begin{array}{l}1-25 \\
(1)\end{array}$} & $\mathrm{OV}$ & 4 & 23 & \multirow{2}{*}{27} \\
\hline & & EV & 10.8 & 16.2 & \\
\hline & \multirow{2}{*}{$\begin{array}{l}26-50 \\
(2)\end{array}$} & $\mathrm{OV}$ & 5 & 8 & \multirow{2}{*}{13} \\
\hline & & EV & 5.2 & 7.8 & \\
\hline & \multirow{2}{*}{$\begin{array}{l}>51 \\
\text { (3) }\end{array}$} & $\mathrm{OV}$ & 25 & 20 & \multirow{2}{*}{45} \\
\hline & & $\overline{E V}$ & 18.0 & 27.0 & \\
\hline \multicolumn{3}{|l|}{ Total } & 34 & 51 & 85 \\
\hline
\end{tabular}

Table 41: Chi Square tests for correlation between the number of employees and having code of business conduct

\begin{tabular}{|c|c|c|c|}
\hline & Value & DF & Asymp. Sig. (2-sided) \\
\hline Pearson Chi-Square & $11.686^{\mathrm{a}}$ & 2 & 0.003 \\
\hline Likelihood Ratio & 12.610 & 2 & 0.002 \\
\hline Linear-by-Linear Association & 11.500 & 1 & 0.001 \\
\hline \# of valid cases & 85 & & \\
\hline
\end{tabular}


Significance Level $($ observed $)=0.003($ Pearson Chi Square $)($ Table 41)

Significance Level $($ chosen $)=0.05$

Significance level of Pearson's Chi-square test is 0.003 which is less than the chosen level of 0.05 . Therefore, there is enough evidence to reject $\mathrm{H}_{0}$ on the 0.05 significance level. It means that there is an association between the number of employees working at the central office and having code of business conduct for construction companies.

In order to identify the degree of association between the variables, Kendall-tau tests are applied. Below table shows the results of Kendall-tau tests.

Table 42: Kendall-tau tests for the number of employees and having code of business conduct

\begin{tabular}{|c|c|c|c|c|}
\hline & Value & Asymp. Std. Error ${ }^{a}$ & Approx. $\mathbf{T}^{\mathrm{b}}$ & Approx. Sig. \\
\hline Kendall's tau-b & -0.351 & 0.090 & -3.825 & 0.000 \\
\hline Kendall's tau-c & -0.375 & 0.098 & -3.825 & 0.000 \\
\hline \# of valid cases & 85 & & & \\
\hline
\end{tabular}

In this case, Kendall-tau-c coefficient is used since the contingency table is rectangular. Kendall-tau-c coefficient is -0.375 and the significance level of Kendall-tau-c coefficient is 0.000 which is less than the significance level of 0.05 . Therefore, on the 0.05 significance level, there is a negative association between variables. 


\section{Result 3:}

The higher the number of employees is working at central offices, the more likely it is that a company has code of business conduct.

\section{Correlation Analysis 4}

$\mathbf{H}_{\mathbf{0}}$ : There is no significant association between number of employees working at central offices of a company and getting external audit services.

Table 43: Contingency table of the number of employees and getting external audit services

\begin{tabular}{|c|c|c|c|c|c|}
\hline & \multicolumn{2}{|c|}{$\begin{array}{l}\text { Does your company get } \\
\text { external audit services? }\end{array}$} & \multirow[t]{2}{*}{ Total } \\
\hline & & & Yes (1) & No (2) & \\
\hline \multirow{6}{*}{$\begin{array}{l}\text { What is the number of } \\
\text { employees working at } \\
\text { the central office of } \\
\text { your company? }\end{array}$} & \multirow{2}{*}{$\begin{array}{l}1-25 \\
\text { (1) }\end{array}$} & $\mathrm{OV}$ & 3 & 24 & \multirow{2}{*}{27} \\
\hline & & EV & 9.5 & 17.5 & \\
\hline & \multirow{2}{*}{$\begin{array}{l}26-50 \\
(2)\end{array}$} & $\mathrm{OV}$ & 4 & 9 & \multirow{2}{*}{13} \\
\hline & & EV & 4.6 & 8.4 & \\
\hline & \multirow{2}{*}{$\begin{array}{l}>51 \\
(3)\end{array}$} & $\mathrm{OV}$ & 23 & 22 & \multirow{2}{*}{45} \\
\hline & & EV & 15.9 & 29.1 & \\
\hline \multicolumn{3}{|l|}{ Total } & 30 & 55 & 85 \\
\hline
\end{tabular}


Table 44: Chi Square tests for correlation between the number of employees and getting external audit services

\begin{tabular}{|l|c|c|c|}
\hline & Value & DF & Asymp. Sig. (2-sided) \\
\hline Pearson Chi-Square & $11.960^{\mathrm{a}}$ & 2 & 0.003 \\
\hline Likelihood Ratio & 13.126 & 2 & 0.001 \\
\hline Linear-by-Linear Association & 11.819 & 1 & 0.001 \\
\hline \# of valid cases & 85 & & \\
\hline
\end{tabular}

a. 1 cell $(16.7 \%)$ has expected count less than 5 . The minimum expected count is 4.59

Significance Level $($ observed $)=0.003($ Pearson Chi Square $)($ Table 44)

Significance Level $($ chosen $)=0.05$

Significance level of Pearson's Chi-square test is 0.003 which is less than the chosen level of 0.05 . Therefore, there is enough evidence to reject $\mathrm{H}_{0}$ on the 0.05 significance level. It means that there is an association between the number of employees working at the central office and getting external audit service for a company.

In order to identify the degree of association between variables, Kendall-tau tests are applied. Below table shows the results of Kendall-tau tests.

Table 45: Kendall-tau tests for the number of employees and getting external audit services

\begin{tabular}{|l|c|c|c|c|}
\hline & Value & Asymp. Std. Error & Approx. T $^{\mathbf{b}}$ & Approx. Sig. \\
\hline Kendall's tau-b & -0.358 & 0.087 & -3.976 & 0.000 \\
\hline Kendall's tau-c & -0.373 & 0.094 & -3.976 & 0.000 \\
\hline \# of valid cases & 85 & & & \\
\hline
\end{tabular}

a. Not assuming the null hypothesis

b. Using the asymptotic standard error assuming the null hypothesis 
In this case, Kendall-tau-c coefficient is used since the contingency table is rectangular. Kendall-tau-c coefficient is -0.373 and the significance level of Kendall-tau-c coefficient is 0.000 which is less than the significance level of 0.05 . Therefore, on the 0.05 significance level, there is a negative association between variables.

\section{$\underline{\text { Result 4: }}$}

The higher the number of employees, the more likely it is for a company to get internal audit services.

\section{Correlation Analysis 5}

$\mathbf{H}_{\mathbf{0}}$ : There is no significant association between the annual revenue of a company and having an internal audit function.

Table 46: Contingency table of the annual revenue of the Company and having internal audit function

\begin{tabular}{|c|c|c|c|c|c|}
\hline & & & \multicolumn{2}{|c|}{$\begin{array}{c}\text { Does your company } \\
\text { have internal audit } \\
\text { services? }\end{array}$} & \multirow[t]{2}{*}{ Total } \\
\hline & & & Yes (1) & No (2) & \\
\hline \multirow{6}{*}{$\begin{array}{l}\text { What is the annual } \\
\text { revenue of the } \\
\text { company? }\end{array}$} & \multirow{2}{*}{$\begin{array}{l}<15 \mathrm{M} \\
(1)\end{array}$} & $\mathrm{OV}$ & 17 & 15 & \multirow{2}{*}{32} \\
\hline & & EV & 22.2 & 9.8 & \\
\hline & \multirow{2}{*}{$\begin{array}{l}15 \mathrm{M}-100 \mathrm{M} \\
\text { (2) }\end{array}$} & OV & 11 & 5 & \multirow{2}{*}{16} \\
\hline & & EV & 11.1 & 4.9 & \\
\hline & \multirow{2}{*}{$\begin{array}{l}>100 \mathrm{M} \\
\text { (3) }\end{array}$} & $\mathrm{OV}$ & 31 & 6 & \multirow{2}{*}{37} \\
\hline & & EV & 25.7 & 11.3 & \\
\hline \multicolumn{3}{|l|}{ Total } & 59 & 26 & 85 \\
\hline
\end{tabular}


Table 47: Chi Square tests for correlation between the annual revenue of the Company and having internal audit function

\begin{tabular}{|c|c|c|c|}
\hline & Value & DF & Asymp. Sig. (2-sided) \\
\hline Pearson Chi-Square & $7.601^{\mathrm{a}}$ & 2 & 0.022 \\
\hline Likelihood Ratio & 7.770 & 2 & 0.021 \\
\hline Linear-by-Linear Association & 7.511 & 1 & 0.006 \\
\hline \# of valid cases & 85 & & \\
\hline
\end{tabular}

Significance Level $($ observed $)=0.022($ Pearson Chi Square $)($ Table 47) Significance Level $($ chosen $)=0.05$

Significance level of Pearson's Chi-square test is 0.022 which is less than the chosen level of 0.05 . Therefore, there is enough evidence to reject $\mathrm{H}_{0}$ on the 0.05 significance level. It means that there is an association between the annual revenue of a company and having internal audit function.

In order to identify the degree of association between variables, Kendall-tau tests are applied. Below table shows the results of Kendall-tau tests.

Table 48: Kendall-tau tests for the annual revenue of the Company and having internal audit function

\begin{tabular}{|c|c|c|c|c|}
\hline & Value & Asymp. Std. Error ${ }^{a}$ & Approx. $T^{b}$ & Approx. Sig. \\
\hline Kendall's tau-b & -0.284 & 0.096 & -2.878 & 0.004 \\
\hline Kendall's tau-c & -0.295 & 0.102 & -2.878 & 0.004 \\
\hline \# of valid cases & 85 & & & \\
\hline
\end{tabular}


In this case, Kendall-tau-c coefficient is used since the contingency table is rectangular. Kendall-tau-c coefficient is -0.295 and the significance level of Kendall-tau-c coefficient is 0.004 which is less than the significance level of 0.05 . Therefore, on the 0.05 significance level, there is a negative association between variables.

\section{Result 5:}

The higher the company revenue, the more likely it is for a company to get external audit services.

\section{Correlation Analysis 6}

$\mathbf{H}_{\mathbf{0}}$ : There is no significant association between the number of employees of a company and having a list of qualified/selected vendors.

Table 49: Contingency table of the number of employees and having list of qualified/selected vendors

\begin{tabular}{|c|c|c|c|c|c|}
\hline & \multicolumn{2}{|c|}{$\begin{array}{c}\text { Does your company have list } \\
\text { of qualified/selected } \\
\text { vendors? }\end{array}$} & \multirow[t]{2}{*}{ Total } \\
\hline & & & Yes (1) & No (2) & \\
\hline \multirow{6}{*}{$\begin{array}{l}\text { What is the number of } \\
\text { employees working at } \\
\text { the central office of your } \\
\text { company? }\end{array}$} & \multirow{2}{*}{$\begin{array}{l}1-25 \\
\text { (1) }\end{array}$} & OV & 15 & 11 & \multirow{2}{*}{26} \\
\hline & & EV & 20.3 & 5.7 & \\
\hline & \multirow{2}{*}{$\begin{array}{l}26-50 \\
(2)\end{array}$} & OV & 11 & 1 & \multirow{2}{*}{12} \\
\hline & & EV & 9.4 & 2.6 & \\
\hline & \multirow{2}{*}{$\begin{array}{l}>51 \\
(3)\end{array}$} & $\mathrm{OV}$ & 38 & 6 & \multirow{2}{*}{44} \\
\hline & & EV & 34.3 & 9.7 & \\
\hline \multicolumn{3}{|l|}{ Total } & 64 & 18 & 82 \\
\hline
\end{tabular}


Table 50: Chi Square tests for correlation between the number of employees and having list of qualified/selected vendors

\begin{tabular}{|l|c|c|c|}
\hline & Value & DF & Asymp. Sig. (2-sided) \\
\hline Pearson Chi-Square & $9.363^{\mathrm{a}}$ & 2 & 0.009 \\
\hline Likelihood Ratio & 8.951 & 2 & 0.011 \\
\hline Linear-by-Linear Association & 6.994 & 1 & 0.008 \\
\hline \# of valid cases & 82 & & \\
\hline
\end{tabular}

a. 1 cell $(16.7 \%)$ has expected count less than 5 . The minimum expected count is 2.63 .

Significance Level $($ observed $)=0.009($ Pearson Chi Square $)($ Table 50)

Significance Level $($ chosen $)=0.05$

Significance level of Pearson's Chi-square test is 0.009 which is less than the chosen level of 0.05 . Therefore, there is enough evidence to reject $\mathrm{H}_{0}$ on the 0.05 significance level. It means that there is an association between the number of employees working at the central office of the Company and having list of a qualified/selected vendors.

In order to identify the degree of association between the variables, Kendall-tau tests are applied. Below table shows the results of Kendall-tau tests. 
Table 51: Kendall-tau tests for the number of employees and having list of qualified/selected vendors

\begin{tabular}{|c|c|c|c|c|}
\hline & Value & Asymp. Std. Error ${ }^{a}$ & Approx. $\mathbf{T}^{b}$ & Approx. Sig. \\
\hline Kendall's tau-b & -0.269 & 0.108 & -2.366 & 0.018 \\
\hline Kendall's tau-c & -0.242 & 0.102 & -2.366 & 0.018 \\
\hline \# of valid cases & 82 & & & \\
\hline
\end{tabular}

In this case, Kendall-tau-c coefficient is used since the contingency table is rectangular. Kendall-tau-c coefficient is -0.242 and the significance level of Kendall-tau-c coefficient is 0.004 which is less than the significance level of 0.05 . Therefore, on the 0.05 significance level, there is a negative association between variables.

$\underline{\text { Result 6: }}$

The higher the number of employees works at the central office of the company, the more likely it will be for the company to have a qualified/selected vendor list.

\section{Correlation Analysis 7}

$\mathbf{H}_{\mathbf{0}}$ : There is no significant association between the annual revenue of the company and having list of qualified/selected vendors. 
Table 52: Contingency table of the annual revenue of the Company and having list of qualified/selected vendors

\begin{tabular}{|c|c|c|c|c|c|}
\hline & \multicolumn{2}{|c|}{$\begin{array}{c}\text { Does your company have } \\
\text { list of qualified/selected } \\
\text { vendors? }\end{array}$} & \multirow[t]{2}{*}{ Total } \\
\hline & & & Yes (1) & No (2) & \\
\hline \multirow{6}{*}{$\begin{array}{l}\text { What is the } \\
\text { annual revenue of } \\
\text { the Company? }\end{array}$} & \multirow{2}{*}{$\begin{array}{l}<15 \mathrm{M} \\
\text { (1) }\end{array}$} & $\mathrm{OV}$ & 21 & 10 & \multirow{2}{*}{31} \\
\hline & & EV & 24.2 & 6.8 & \\
\hline & \multirow{2}{*}{$\begin{array}{l}15 M-100 M \\
\text { (2) }\end{array}$} & $\mathrm{OV}$ & 11 & 5 & \multirow{2}{*}{16} \\
\hline & & EV & 12.5 & 3.5 & \\
\hline & \multirow{2}{*}{$\begin{array}{l}>100 \mathrm{M} \\
\text { (3) }\end{array}$} & $\mathrm{OV}$ & 32 & 3 & \multirow{2}{*}{35} \\
\hline & & $\overline{\mathrm{EV}}$ & 27.3 & 7.7 & \\
\hline \multicolumn{3}{|l|}{ Total } & 64 & 18 & 82 \\
\hline
\end{tabular}

Table 53: Chi Square tests for correlation between the annual revenue of the Company and having list of qualified/selected vendors

\begin{tabular}{|l|c|c|c|}
\hline & Value & DF & Asymp. Sig. (2-sided) \\
\hline Pearson Chi-Square & $6.387^{\mathrm{a}}$ & 2 & 0.041 \\
\hline Likelihood Ratio & 6.976 & 2 & 0.031 \\
\hline Linear-by-Linear Association & 5.438 & 1 & 0.020 \\
\hline \# of valid cases & 82 & & \\
\hline
\end{tabular}

a. 1 cell $(16.7 \%)$ has expected count less than 5 . The minimum expected count is 3.51 .

Significance Level (observed) $=0.041($ Pearson Chi Square) $($ Table 53)

Significance Level $($ chosen $)=0.05$

Significance level of Pearson's Chi-square test is 0.041 which is less than the chosen level of 0.05 . Therefore, there is enough evidence to reject $\mathrm{H}_{0}$ on the 0.05 significance level. It means that there is an association between the annual 
revenue of the Companies and having list of qualified/selected vendors.

In order to identify the degree of association between the variables, Kendall-tau tests are applied. Below table shows the results of Kendall-tau tests.

Table 54: Kendall-tau tests for the annual revenue of the Company and having list of qualified/selected vendors

\begin{tabular}{|c|c|c|c|c|}
\hline & Value & Asymp. Std. Error & Approx. $\mathbf{T}^{\mathrm{b}}$ & Approx. Sig. \\
\hline Kendall's tau-b & -0.248 & 0.093 & -2.518 & 0.012 \\
\hline Kendall's tau-c & -0.231 & 0.092 & -2.518 & 0.012 \\
\hline \# of valid cases & 82 & & & \\
\hline
\end{tabular}

In this case, Kendall-tau-c coefficient is used since the contingency table is rectangular. Kendall-tau-c coefficient is -0.231 and the significance level of Kendall-tau-c coefficient is 0.012 which is less than the significance level of 0.05 . Therefore, on the 0.05 significance level, there is a negative association between variables.

\section{Result 7:}

The higher the company revenue, the more likely it will be for the company to have qualified/selected vendor lists.

\section{Correlation Analysis 8}

$\mathbf{H}_{\mathbf{0}}$ : There is no significant association between the annual revenue of a company and having requirements to obtain bids from multiple vendors. 
Table 55: Contingency table of the annual revenue of the Company and having requirements to obtain bids from multiple vendors

\begin{tabular}{|c|c|c|c|c|c|}
\hline & \multicolumn{2}{|c|}{$\begin{array}{c}\text { Does your company have } \\
\text { requirements to obtain bids from } \\
\text { multiple vendors? }\end{array}$} & \multirow[t]{2}{*}{ Total } \\
\hline & & & Yes (1) & No (2) & \\
\hline \multirow{6}{*}{$\begin{array}{l}\text { What is the } \\
\text { annual revenue } \\
\text { of the Company? }\end{array}$} & \multirow{2}{*}{$\begin{array}{l}<15 \mathrm{M} \\
\text { (1) }\end{array}$} & OV & 20 & 10 & \multirow{2}{*}{30} \\
\hline & & EV & 24.3 & 5.7 & \\
\hline & \multirow{2}{*}{$\begin{array}{l}15 M-100 M \\
\text { (2) }\end{array}$} & $\mathrm{OV}$ & 15 & 3 & \multirow{2}{*}{18} \\
\hline & & EV & 14.6 & 3.4 & \\
\hline & \multirow{2}{*}{$\begin{array}{l}>100 \mathrm{M} \\
\text { (3) }\end{array}$} & $\mathrm{OV}$ & 33 & 3 & \multirow{2}{*}{36} \\
\hline & & EV & 29.1 & 6.9 & \\
\hline \multicolumn{3}{|l|}{ Total } & 68 & 16 & 84 \\
\hline
\end{tabular}

Table 56: Chi Square tests for correlation between the annual revenue of the Company and having requirements to obtain bids from multiple vendors

\begin{tabular}{|c|c|c|c|}
\hline & Value & $\overline{\text { DF }}$ & Asymp. Sig. (2-sided) \\
\hline Pearson Chi-Square & $6.717^{\mathrm{a}}$ & 2 & 0.035 \\
\hline Likelihood Ratio & 6.738 & 2 & 0.034 \\
\hline Linear-by-Linear Association & 6.480 & 1 & 0.011 \\
\hline \# of valid cases & 84 & & \\
\hline
\end{tabular}

Significance Level (observed) $=0.035$ (Pearson Chi Square) $($ Table 56)

Significance Level $($ chosen $)=0.05$

Significance level of Pearson's Chi-square test is 0.035 which is less than the chosen level of 0.05 . Therefore, there is enough evidence to reject $\mathrm{H}_{0}$ on the 0.05 significance level. It means that there is an association between the annual 
revenue of the Companies and having list of qualified/selected vendors.

In order to identify the degree of association between the variables, Kendall-tau tests are applied. Below table shows the results of Kendall-tau tests.

Table 57: Kendall-tau tests for the annual revenue of the Company and having requirements to obtain bids from multiple vendors

\begin{tabular}{|c|c|c|c|c|}
\hline & Value & Asymp. Std. Error ${ }^{a}$ & Approx. $\mathbf{T}^{\mathrm{b}}$ & Approx. Sig. \\
\hline Kendall's tau-b & -0.264 & 0.095 & -2.563 & 0.010 \\
\hline Kendall's tau-c & -0.235 & 0.092 & -2.563 & 0.010 \\
\hline \# of valid cases & 84 & & & \\
\hline
\end{tabular}

In this case, Kendall-tau-c coefficient is used since the contingency table is rectangular. Kendall-tau-c coefficient is -0.235 and the significance level of Kendall-tau-c coefficient is 0.012 which is less than the significance level of 0.05 . Therefore, on the 0.05 significance level, there is a negative association between the variables.

\section{$\underline{\text { Result } 8}$}

The higher the company revenue, the more likely it will be for the company to have requirements to obtain bids from multiple vendors.

\section{Correlation Analysis 9}

$\mathbf{H}_{0}$ : There is no significant association between the number of employees of a company and having segregated purchase order and vendor selection functions. 
Table 58: Contingency table of the annual revenue of the Company and having segregated purchase order and vendor selection functions

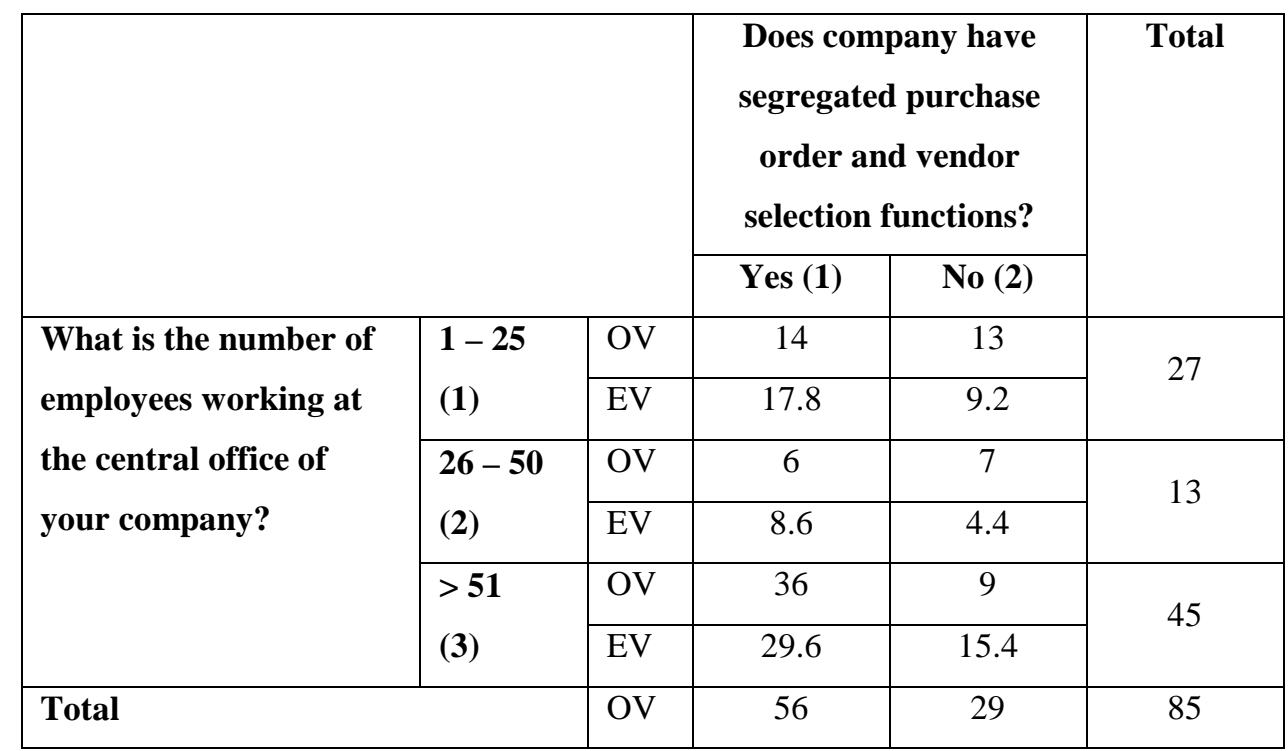

Table 59: Chi Square tests for correlation between the annual revenue of the Company and having segregated purchase order and vendor selection functions

\begin{tabular}{|c|c|c|c|}
\hline & Value & $\mathbf{D F}$ & Asymp. Sig. (2-sided) \\
\hline Pearson Chi-Square & $8.606^{\mathrm{a}}$ & 2 & 0.014 \\
\hline Likelihood Ratio & 8.734 & 2 & 0.013 \\
\hline Linear-by-Linear Association & 6.631 & 1 & 0.010 \\
\hline \# of valid cases & 85 & & \\
\hline
\end{tabular}

Significance Level $($ observed $)=0.014($ Pearson Chi Square $)($ Table 59)

Significance Level $($ chosen $)=0.05$

Significance level of Pearson's Chi-square test is 0.014 which is less than the chosen level of 0.05 . Therefore, there is enough evidence to reject $\mathrm{H}_{0}$ on the 0.05 
significance level. It means that there is an association between the number of employees working for the company and segregation of purchase order and vendor selection functions.

In order to identify the degree of association between the variables, Kendall-tau tests are applied. Below table shows the results of Kendall-tau tests.

Table 60: Kendall-tau tests for the annual revenue of the Company and having segregated purchase order and vendor selection functions

\begin{tabular}{|c|c|c|c|c|}
\hline & Value & Asymp. Std. Error ${ }^{a}$ & Approx. $T^{b}$ & Approx. Sig. \\
\hline Kendall's tau-b & -0.278 & 0.099 & -2.769 & 0.006 \\
\hline Kendall's tau-c & -0.288 & 0.104 & -2.769 & 0.006 \\
\hline \# of valid cases & 85 & & & \\
\hline
\end{tabular}

In this case, Kendall-tau-c coefficient is used since the contingency table is rectangular. Kendall-tau-c coefficient is -0.288 and the significance level of Kendall-tau-c coefficient is 0.006 which is less than the significance level of 0.05 . Therefore, on the 0.05 significance level, there is a negative association between variables.

\section{$\underline{\text { Result 9: }}$}

The higher the number of employees, the more likely it will be for the company to segregate purchase order and vendor selection functions.

\section{Correlation Analysis 10}

$\mathbf{H}_{\mathbf{0}}$ : There is no significant association between the number of employees working 
for a company and, verification of education and certificate information of job applicants

Table 61: Contingency table of the number of employees and verification of education and certificate information of job applicants

\begin{tabular}{|c|c|c|c|c|c|}
\hline & & & \multicolumn{2}{|c|}{$\begin{array}{l}\text { Does your company } \\
\text { verify education and } \\
\text { certificate information } \\
\text { of job applicants? }\end{array}$} & \multirow[t]{2}{*}{ Total } \\
\hline & & & Yes (1) & No (2) & \\
\hline \multirow{6}{*}{$\begin{array}{l}\text { What is the number of } \\
\text { employees working at } \\
\text { the central office of } \\
\text { your company? }\end{array}$} & $1-25$ & OV & 5 & 21 & \multirow{2}{*}{26} \\
\hline & (1) & EV & 7.0 & 19.0 & \\
\hline & $26-50$ & OV & 1 & 13 & \multirow{2}{*}{14} \\
\hline & (2) & EV & 3.8 & 10.2 & \\
\hline & $>51$ & $\mathrm{OV}$ & 16 & 26 & \multirow{2}{*}{42} \\
\hline & (3) & EV & 11.3 & 30.7 & \\
\hline \multicolumn{2}{|l|}{ Total } & OV & 22 & 60 & 82 \\
\hline
\end{tabular}

Table 62: Chi Square tests for correlation between the number of employees and verification of education and certificate information of job applicants

\begin{tabular}{|l|c|c|c|}
\hline & Value & DF & Asymp. Sig. (2-sided) \\
\hline Pearson Chi-Square & $6.244^{\mathrm{a}}$ & 2 & 0.044 \\
\hline Likelihood Ratio & 6.893 & 2 & 0.032 \\
\hline Linear-by-Linear Association & 3.489 & 1 & 0.062 \\
\hline \# of valid cases & 82 & & \multicolumn{4}{|c|}{. Thinimum expected count is 3.51. } \\
a. 1 cell (16.7\%) has expected count less than
\end{tabular}

Significance Level $($ observed $)=0.044($ Pearson Chi Square $)($ Table 62) 
Significance Level $($ chosen $)=0.05$

Significance level of Pearson's Chi-square test is 0.044 which is less than the chosen level of 0.05 . Therefore, there is enough evidence to reject $\mathrm{H}_{0}$ on the 0.05 significance level. It means that there is an association between the number of employees working for the company and verification of education/certificate information of job applicants.

In order to identify the degree of association between variables, Kendall-tau tests are applied. Below table shows the results of Kendall-tau tests.

Table 63: Kendall-tau tests for the number of employees and verification of education and certificate information of job applicants

\begin{tabular}{|c|c|c|c|c|}
\hline & Value & Asymp. Std. Error ${ }^{a}$ & Approx. $\mathbf{T}^{\mathrm{b}}$ & Approx. Sig. \\
\hline Kendall's tau-b & -0.209 & 0.101 & -2.022 & 0.043 \\
\hline Kendall's tau-c & -0.205 & 0.101 & -2.022 & 0.043 \\
\hline \# of valid cases & 82 & & & \\
\hline
\end{tabular}

In this case, Kendall-tau-c coefficient is used since the contingency table is rectangular. Kendall-tau-c coefficient is -0.205 and the significance level of Kendall-tau-c coefficient is 0.043 which is less than the significance level of 0.05 . Therefore, on the 0.05 significance level, there is a negative association between variables.

\section{$\underline{\text { Result 10: }}$}

The higher the number of employees, the more likely it will be for the company to verify education/certificate information of job applicants. 


\section{Correlation Analysis 11:}

$\mathbf{H}_{\mathbf{0}}$ : There is no significant association between experiencing a fraud case and believing that the company is under the risk of fraud.

Table 64: Contingency table of experiencing a fraud case and thinking that the Company is under fraud risk

\begin{tabular}{|c|c|c|c|c|c|}
\hline & \multicolumn{2}{|c|}{$\begin{array}{l}\text { Do you think that your } \\
\text { company is under the } \\
\text { risk of internal fraud? }\end{array}$} & \multirow[t]{2}{*}{ Total } \\
\hline & & & Yes (1) & No (2) & \\
\hline \multirow{4}{*}{$\begin{array}{l}\text { Has your company } \\
\text { experienced a fraud } \\
\text { case in the last three } \\
\text { years? }\end{array}$} & \multirow{2}{*}{$\begin{array}{l}\text { Yes } \\
\text { (1) }\end{array}$} & $\mathrm{OV}$ & 31 & 12 & \multirow{2}{*}{43} \\
\hline & & EV & 20.8 & 22.2 & \\
\hline & \multirow{2}{*}{$\begin{array}{l}\text { No } \\
\text { (2) }\end{array}$} & $\mathrm{OV}$ & 1 & 22 & \multirow{2}{*}{23} \\
\hline & & EV & 11.2 & 11.8 & \\
\hline \multicolumn{3}{|l|}{ Total } & 32 & 34 & 66 \\
\hline
\end{tabular}

Table 65: Chi Square tests for correlation between experiencing a fraud case and thinking that the Company is under fraud risk

\begin{tabular}{|c|c|c|c|c|c|}
\hline & Value & DF & $\begin{array}{c}\text { Asymp. Sig. } \\
\text { (2-sided) }\end{array}$ & $\begin{array}{l}\text { Exact Sig. } \\
\text { (2-sided) }\end{array}$ & $\begin{array}{l}\text { Exact Sig. } \\
\text { (1-sided) }\end{array}$ \\
\hline Pearson Chi-Square & $27.534^{\mathrm{a}}$ & 1 & 0.000 & & \\
\hline Continuity Correction $^{\mathrm{b}}$ & 24.888 & 1 & 0.000 & & \\
\hline Likelihood Ratio & 32.290 & 1 & 0.000 & & \\
\hline Fisher's Exact Test & & & & 0.000 & 0.000 \\
\hline $\begin{array}{l}\text { Linear-by-Linear } \\
\text { Association }\end{array}$ & 27.117 & 1 & 0.000 & & \\
\hline \# of valid cases & 66 & & & & \\
\hline
\end{tabular}

a. 0 cells $(, 0 \%)$ have expected count less than 5 . The minimum expected count is 11.15 .

b. Computed only for a $2 \times 2$ table 
Significance Level $($ observed $)=0.000$ (Fisher's exact test) $($ Table 65)

Significance Level $($ chosen $)=0.05$

Significance level of Fisher's exact test is 0.000 which is less than the chosen level of 0.05 . Therefore, there is enough evidence to reject $\mathrm{H}_{0}$ on the 0.05 significance level. It means that there is an association between experiencing a fraud case and believing that the company is under the risk of fraud.

In order to identify the degree of association between the variables, Kendall-tau tests are applied. Below table shows the results of Kendall-tau tests.

Table 66: Kendall-tau tests for experiencing a fraud case and thinking that the Company is under fraud risk

\begin{tabular}{|c|c|c|c|c|}
\hline & Value & Asymp. Std. Error ${ }^{a}$ & Approx. $\mathbf{T}^{\mathrm{b}}$ & Approx. Sig. \\
\hline Kendall's tau-b & 0.646 & 0.080 & 7.025 & 0.000 \\
\hline Kendall's tau-c & 0.615 & 0.088 & 7.025 & 0.000 \\
\hline \# of valid cases & 66 & & & \\
\hline
\end{tabular}

In this case, Kendall-tau-b coefficient is used since the contingency table is square shaped. Kendall-tau-b coefficient is 0.646 and the significance level of Kendalltau-b coefficient is 0.000 which is less than the significance level of 0.05 . Therefore, on the 0.05 significance level, there is strong positive association between the variables.

\section{$\underline{\text { Result 11: }}$}

The respondents who experienced fraud case are more likely to believe that the company is under the risk of fraud. 


\section{Correlation Analysis 12:}

$\mathbf{H}_{\mathbf{0}}$ : There is no significant association between a company's revenue and the likelihood of a company to be victimized by any kind of fraud.

Table 67: Contingency table of the annual revenue of the Company and being victim of internal fraud

\begin{tabular}{|c|c|c|c|c|c|}
\hline & \multicolumn{2}{|c|}{$\begin{array}{l}\text { Has your company } \\
\text { been the victim of any } \\
\text { sort of internal fraud in } \\
\text { the last three years? }\end{array}$} & \multirow[t]{2}{*}{ Total } \\
\hline & & & Yes (1) & No (2) & \\
\hline \multirow{6}{*}{$\begin{array}{l}\text { What is the } \\
\text { annual revenue } \\
\text { of the Company? }\end{array}$} & \multirow{2}{*}{$\begin{array}{l}<15 \mathrm{M} \\
\text { (1) }\end{array}$} & $\mathrm{OV}$ & 15 & 12 & \multirow{2}{*}{27} \\
\hline & & EV & 17.6 & 9.4 & \\
\hline & \multirow{2}{*}{$\begin{array}{l}15 M-100 M \\
\text { (2) }\end{array}$} & $\overline{\mathrm{OV}}$ & 10 & 3 & \multirow{2}{*}{13} \\
\hline & & $\overline{E V}$ & 8.5 & 4.5 & \\
\hline & \multirow{2}{*}{$\begin{array}{l}>100 \mathrm{M} \\
\text { (3) }\end{array}$} & $\mathrm{OV}$ & 18 & 8 & \multirow{2}{*}{26} \\
\hline & & $\mathrm{EV}$ & 16.9 & 9.1 & \\
\hline \multicolumn{3}{|l|}{ Total } & 43 & 23 & 66 \\
\hline
\end{tabular}

Table 68: Chi Square tests for correlation between the annual revenue of the Company and being victim of internal fraud

\begin{tabular}{|c|c|c|c|}
\hline & Value & $\overline{\text { DF }}$ & Asymp. Sig. (2-sided) \\
\hline Pearson Chi-Square & $2.079^{\mathrm{a}}$ & 2 & 0.354 \\
\hline Likelihood Ratio & 2.101 & 2 & 0.350 \\
\hline Linear-by-Linear Association & 1.092 & 1 & 0.296 \\
\hline \# of valid cases & 66 & & \\
\hline
\end{tabular}


Significance Level $($ observed $)=0.354($ Pearson Chi-Square $)($ Table 68)

Significance Level $($ chosen $)=0.05$

Significance level of Pearson's Chi-square test is 0.354 which is greater than the chosen level of 0.05 .

\section{Result 12:}

There is not enough evidence to reject $\mathrm{H}_{0}$ hypothesis on the 0.05 significance level.

\section{Correlation Analysis 13}

$\mathbf{H}_{\mathbf{0}}$ : There is no significant association between the number of expertise areas of a company and its likelihood of being a victim of any kind of fraud.

Table 69: Contingency table of the number of expertise areas and being victim of internal fraud

\begin{tabular}{|c|c|c|c|c|c|}
\hline & \multicolumn{2}{|c|}{$\begin{array}{c}\text { Has your company } \\
\text { been victim of any sort } \\
\text { of internal fraud in the } \\
\text { last three years? }\end{array}$} & \multirow[t]{2}{*}{ Total } \\
\hline & & & Yes (1) & No (2) & \\
\hline \multirow{6}{*}{$\begin{array}{l}\text { In how many different } \\
\text { expertise areas does } \\
\text { your company perform } \\
\text { projects? }\end{array}$} & \multirow{2}{*}{$1(1)$} & $\mathrm{OV}$ & 18 & 14 & \multirow{2}{*}{32} \\
\hline & & $\mathrm{EV}$ & 20.8 & 11.2 & \\
\hline & \multirow{2}{*}{$2(2)$} & $\mathrm{OV}$ & 14 & 8 & \multirow{2}{*}{22} \\
\hline & & EV & 14.3 & 7.7 & \\
\hline & \multirow{2}{*}{$>2(3)$} & $\mathrm{OV}$ & 11 & 1 & \multirow{2}{*}{12} \\
\hline & & $\mathrm{EV}$ & 7.8 & 4.2 & \\
\hline \multicolumn{2}{|l|}{ Total } & $\mathrm{OV}$ & 43 & 23 & 66 \\
\hline
\end{tabular}


Table 70: Chi Square tests for correlation between the number of expertise areas and being victim of internal fraud

\begin{tabular}{|l|c|c|c|}
\hline & Value & DF & Asymp. Sig. (2-sided) \\
\hline Pearson Chi-Square & $4.855^{\text {a }}$ & 2 & 0.088 \\
\hline Likelihood Ratio & 5.753 & 2 & 0.056 \\
\hline Linear-by-Linear Association & 4.158 & 1 & 0.041 \\
\hline \# of valid cases & 66 & & \\
\hline
\end{tabular}

a. 1 cell $(16.7 \%)$ has expected count less than 5 . The minimum expected count is 4.18 .

Significance Level $($ observed $)=0.088($ Pearson Chi-Square $)($ Table 70$)$

Significance Level $($ chosen $)=0.05$

Significance level of Pearson's Chi-square test is 0.088 which is greater than the chosen level of 0.05 .

\section{Result 13:}

There is not enough evidence to reject $\mathrm{H}_{0}$ hypothesis on the 0.05 significance level.

\section{Correlation Analysis 14}

$\mathbf{H}_{0}$ : There is no significant association between performing projects abroad and the likelihood of a company being a victim of any kind of fraud. 
Table 71: Contingency table of performing projects abroad and being victim of internal fraud

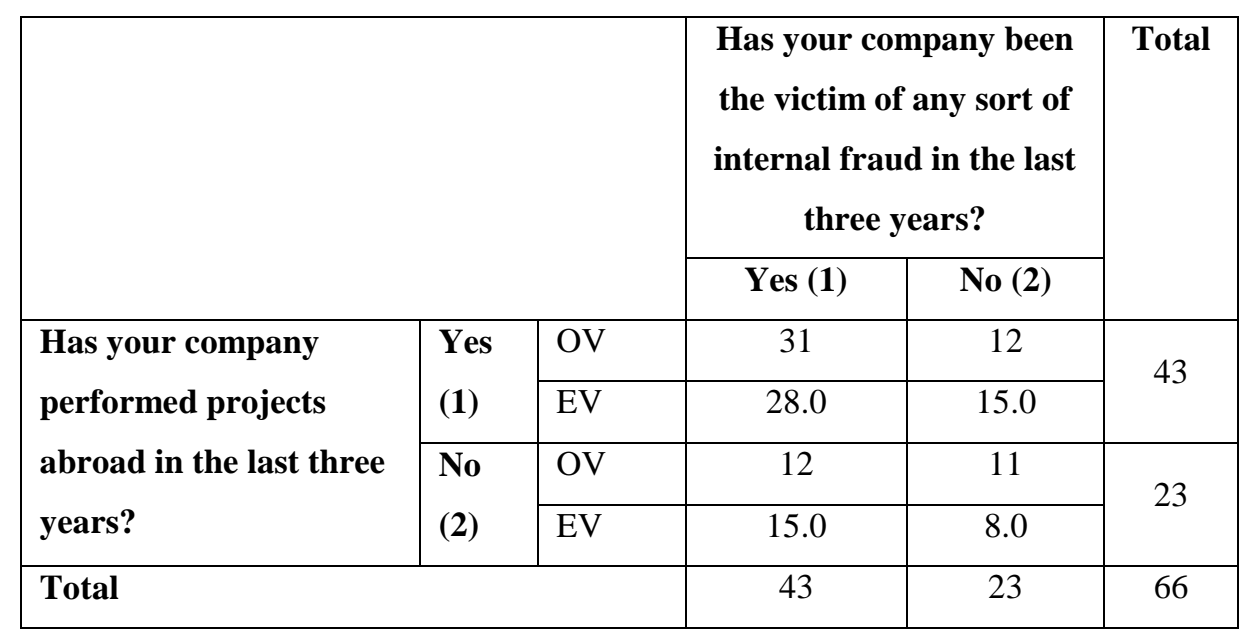

Table 72: Chi Square tests for correlation between performing projects abroad and being victim of internal fraud

\begin{tabular}{|l|c|c|c|c|c|}
\hline & Value & DF & $\begin{array}{c}\text { Asymp. Sig. } \\
\text { (2-sided) }\end{array}$ & $\begin{array}{c}\text { Exact Sig. } \\
\text { (2-sided) }\end{array}$ & $\begin{array}{c}\text { Exact Sig. } \\
\text { (1-sided) }\end{array}$ \\
\hline Pearson Chi-Square & $2.619^{\mathrm{a}}$ & 1 & 0.106 & & \\
\hline Continuity Correction $^{\mathrm{b}}$ & 1.815 & 1 & 0.178 & & \\
\hline Likelihood Ratio & 2.579 & 1 & 0.108 & & \\
\hline Fisher's Exact Test & & & & 0.174 & 0.090 \\
\hline $\begin{array}{l}\text { Linear-by-Linear } \\
\text { Association }\end{array}$ & 2.579 & 1 & 0.108 & & \\
\hline \# of valid cases & 66 & & & & \\
\hline
\end{tabular}

a. 0 cells $(, 0 \%)$ have expected count less than 5 . The minimum expected count is 8.02 .

b. Computed only for a $2 \times 2$ table

Significance Level $($ observed $)=0.174$ (Fisher's exact test) $($ Table 72$)$

Significance Level $($ chosen $)=0.05$ 
Significance level of Fisher's exact test is 0.174 which is less than the chosen level of 0.05 .

Result 14:

There is not enough evidence to reject $\mathrm{H}_{0}$ hypothesis on the 0.05 significance level.

\section{Correlation Analysis 15}

$\mathbf{H}_{\mathbf{0}}$ : There is no significant association between having internal audit services and the likelihood of the company being a victim of any kind of fraud.

Table 73: Contingency table of having internal audit services in place and being victim of internal fraud

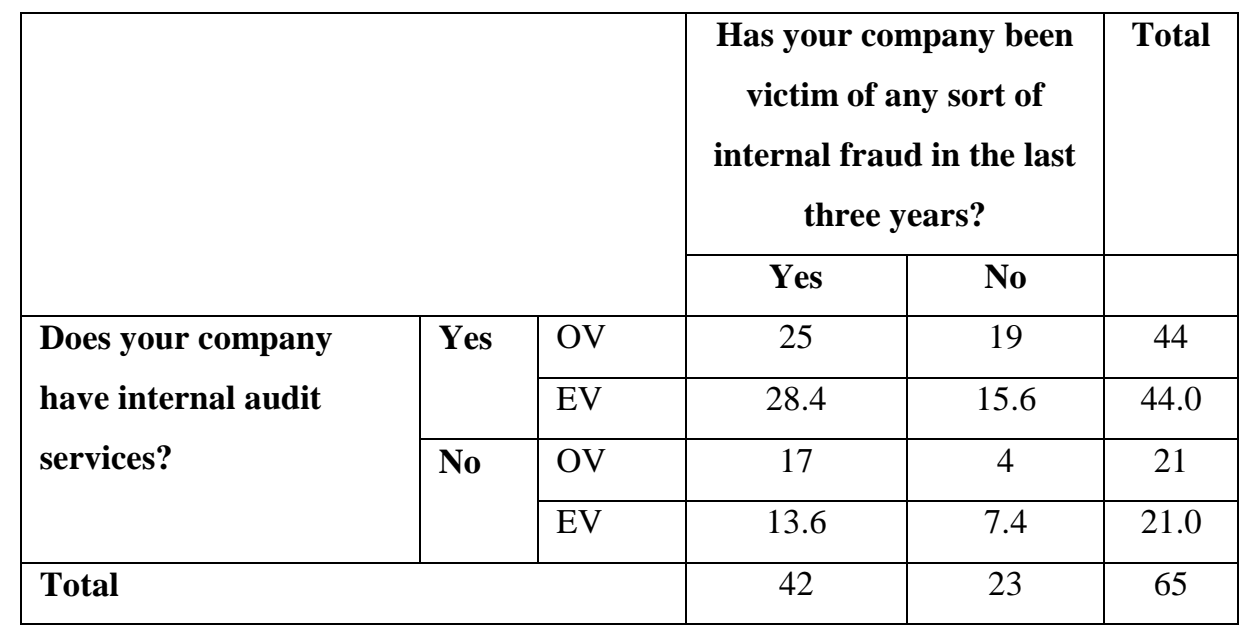


Table 74: Chi Square tests for correlation between having internal audit services in place and being a victim of internal fraud

\begin{tabular}{|c|c|c|c|c|c|}
\hline & Value & DF & $\begin{array}{c}\text { Asymp. Sig. } \\
\text { (2-sided) }\end{array}$ & $\begin{array}{l}\text { Exact Sig. } \\
\text { (2-sided) }\end{array}$ & $\begin{array}{l}\text { Exact Sig. } \\
\text { (1-sided) }\end{array}$ \\
\hline Pearson Chi-Square & $3.621^{\mathrm{a}}$ & 1 & 0.057 & & \\
\hline Continuity Correction $^{b}$ & 2.643 & 1 & 0.104 & & \\
\hline Likelihood Ratio & 3.847 & 1 & 0.050 & & \\
\hline Fisher's Exact Test & & & & 0.095 & 0.050 \\
\hline $\begin{array}{l}\text { Linear-by-Linear } \\
\text { Association }\end{array}$ & 3.566 & 1 & 0.059 & & \\
\hline \# of valid cases & 65 & & & & \\
\hline
\end{tabular}

Significance Level (observed) $=0.095$ (Fisher's exact test) $($ Table 74)

Significance Level $($ chosen $)=0.05$

Significance level of Fisher's exact test is 0.174 which is less than the chosen level of 0.05 .

\section{Result 15:}

There is not enough evidence to reject $\mathrm{H}_{0}$ hypothesis on the 0.05 significance level.

\section{Correlation Analysis 16}

$\mathbf{H}_{\mathbf{0}}$ : There is no significant association between checking the references of job applicants and the likelihood of the company being a victim of any kind of fraud. 
Table 75: Contingency table of checking the references of job applicants and being victim of internal fraud

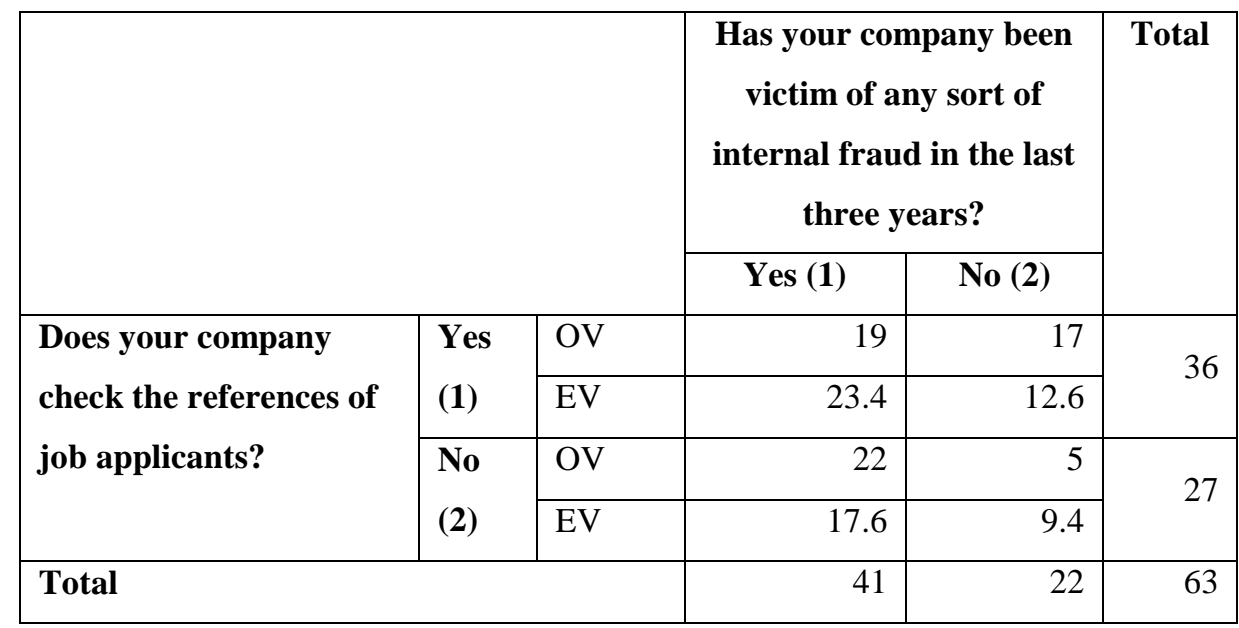

Table 76: Chi Square tests for correlation between checking the references of job applicants and being victim of internal fraud

\begin{tabular}{|c|c|c|c|c|c|}
\hline & Value & DF & $\begin{array}{l}\text { Asymp. Sig. } \\
\text { (2-sided) }\end{array}$ & $\begin{array}{l}\text { Exact Sig. } \\
\text { (2-sided) }\end{array}$ & $\begin{array}{c}\text { Exact Sig. } \\
\text { (1-sided) }\end{array}$ \\
\hline Pearson Chi-Square & $5.593^{\mathrm{a}}$ & 1 & 0.018 & & \\
\hline Continuity Correction $^{b}$ & 4.402 & 1 & 0.036 & & \\
\hline Likelihood Ratio & 5.846 & 1 & 0.016 & & \\
\hline Fisher's Exact Test & & & & ,032 & 017 \\
\hline $\begin{array}{l}\text { Linear-by-Linear } \\
\text { Association }\end{array}$ & 5.505 & 1 & ,019 & & \\
\hline \# of valid cases & 63 & & & & \\
\hline
\end{tabular}

a. 0 cells $(, 0 \%)$ have expected count less than 5 . The minimum expected count is 9.43 .

b. Computed only for a $2 \times 2$ table

Significance Level $($ observed $)=0.032$ (Fisher's exact test) $($ Table 76$)$

Significance Level $($ chosen $)=0.05$ 
Significance level of Fisher's exact test is 0.032 which is less than the chosen level of 0.05 . Therefore, there is enough evidence to reject $\mathrm{H}_{0}$ on the 0.05 significance level. It means that there is an association between checking the references of job applicants and likelihood of the Company being a victim of any kind of fraud.

In order to identify the degree of association between variables, Kendall-tau tests are applied. Below table shows the results of Kendall-tau tests.

Table 77: Kendall-tau tests for checking the references of job applicants and being victim of internal fraud

\begin{tabular}{|c|c|c|c|c|}
\hline & Value & Asymp. Std. Error ${ }^{a}$ & Approx. $\mathbf{T}^{\mathrm{b}}$ & Approx. Sig. \\
\hline Kendall's tau-b & -0.298 & 0.114 & -2.555 & 0.011 \\
\hline Kendall's tau-c & -0.281 & 0.110 & -2.555 & 0.011 \\
\hline \# of valid cases & 63 & & & \\
\hline
\end{tabular}

In this case, Kendall-tau-b coefficient is used since the contingency table is square shaped. Kendall-tau-b coefficient is -0.298 and the significance level of Kendalltau-b coefficient is 0.011 which is less than the significance level of 0.05 . Therefore, on the 0.05 significance level, there is a negative association between the variables.

\section{Result 16:}

The Companies that check the references of job applicants are less likely to experience fraud. 


\section{Correlation Analysis 17}

$\mathbf{H}_{\mathbf{0}}$ : There is no significant association between permitting/encouraging facilitation payments and the likelihood of a company being a victim of any kind of fraud.

Table 78: Contingency table of permitting/encouraging facilitation payments and being victim of internal fraud

\begin{tabular}{|c|c|c|c|c|c|}
\hline & \multicolumn{2}{|c|}{$\begin{array}{l}\text { Has your company been } \\
\text { victim of any sort of } \\
\text { internal fraud in the last } \\
\text { three years? }\end{array}$} & \multirow[t]{2}{*}{ Total } \\
\hline & & & Yes (1) & No (2) & \\
\hline \multirow{4}{*}{$\begin{array}{l}\text { Does your company } \\
\text { permit/encourage } \\
\text { facilitation payments? }\end{array}$} & Yes & $\mathrm{OV}$ & 25 & 7 & \multirow{2}{*}{32} \\
\hline & (1) & EV & 20.7 & 11.3 & \\
\hline & No & $\mathrm{OV}$ & 8 & 11 & \multirow{2}{*}{19} \\
\hline & (2) & EV & 12.3 & 6.7 & \\
\hline \multicolumn{3}{|l|}{ Total } & 33 & 18 & 51 \\
\hline
\end{tabular}

Table 79: Chi Square tests for correlation between permitting/encouraging facilitation payments and being victim of internal fraud

\begin{tabular}{|l|r|r|r|r|r|}
\hline & Value & DF & $\begin{array}{r}\text { Asymp. Sig. } \\
\text { (2-sided) }\end{array}$ & $\begin{array}{c}\text { Exact Sig. } \\
\text { (2-sided) }\end{array}$ & $\begin{array}{c}\text { Exact Sig. } \\
\text { (1-sided) }\end{array}$ \\
\hline Pearson Chi-Square & $6.773^{\mathrm{a}}$ & 1 & 0.009 & & \\
\hline Continuity Correction $^{\mathrm{b}}$ & 5.287 & 1 & 0.021 & & \\
\hline Likelihood Ratio $^{\text {2 }}$ & 6.739 & 1 & 0.009 & & \\
\hline Fisher's Exact Test & & & & 0.015 & \\
\hline Linear-by-Linear Association & 6.640 & 1 & 0.010 & & \\
\hline \# of valid cases & 51 & & & & \\
\hline
\end{tabular}

a. 0 cells $(, 0 \%)$ have expected count less than 5 . The minimum expected count is 6.71 .

b. Computed only for a $2 \times 2$ table 
Significance Level $($ observed $)=0.015$ (Fisher's exact test) $($ Table 79$)$

Significance Level $($ chosen $)=0.05$

Significance level of Fisher's exact test is 0.015 which is less than the chosen level of 0.05 . Therefore, there is enough evidence to reject $\mathrm{H}_{0}$ on the 0.05 significance level. It means that there is an association between permitting/encouraging facilitation payments and the likelihood of the company to being a victim of any kind of fraud.

In order to identify the degree of association between variables, Kendall-tau tests are applied. Below table shows the results of Kendall-tau tests.

Table 80: Kendall-tau tests for permitting/encouraging facilitation payments and being victim of internal fraud

\begin{tabular}{|c|c|c|c|c|}
\hline & Value & Asymp. Std. Error ${ }^{a}$ & Approx. $\mathbf{T}^{\mathbf{b}}$ & Approx. Sig. \\
\hline Kendall's tau-b & 0.364 & 0.135 & 2.622 & 0.009 \\
\hline Kendall's tau-c & 0.337 & 0.128 & 2.622 & 0.009 \\
\hline \# of valid cases & 51 & & & \\
\hline
\end{tabular}

In this case, Kendall-tau-b coefficient is used since the contingency table is square shaped. Kendall-tau-b coefficient is 0.364 and the significance level of Kendalltau-b coefficient is 0.009 which is less than the significance level of 0.05 . Therefore, on the 0.05 significance level, there is a positive association between the variables.

$\underline{\text { Result 17: }}$ 
The companies which permit/encourage facilitation payments are more likely to experience fraud.

\section{Correlation Analysis 18}

$\mathbf{H}_{\mathbf{0}}$ : There is no significant association between considering "organizing entertainment events for the employers" is acceptable for the survival of the company and the likelihood of the company being a victim of any kind of fraud.

Table 81: Contingency table of organizing entertainments for employers for the survival of your company and being victim of internal fraud

\begin{tabular}{|c|c|c|c|c|c|}
\hline & \multicolumn{2}{|c|}{$\begin{array}{l}\text { Has your company been victim } \\
\text { of any sort of internal fraud in } \\
\text { the last three years? }\end{array}$} & \multirow[t]{2}{*}{ Total } \\
\hline & & & Yes (1) & No (2) & \\
\hline \multirow{4}{*}{$\begin{array}{l}\text { Is organizing } \\
\text { entertainments for } \\
\text { employers acceptable } \\
\text { for the survival of your } \\
\text { company? }\end{array}$} & \multirow{2}{*}{$\begin{array}{l}\text { Yes } \\
\text { (1) }\end{array}$} & OV & 17 & 4 & \multirow{2}{*}{21} \\
\hline & & EV & 13.8 & 7.2 & \\
\hline & No & $\mathrm{OV}$ & 25 & 18 & \multirow[b]{2}{*}{43} \\
\hline & (2) & EV & 28.2 & 14.8 & \\
\hline \multicolumn{3}{|l|}{ Total } & 42 & 22 & 64 \\
\hline
\end{tabular}


Table 82: Chi Square tests for correlation organizing entertainments for employers for the survival of your company and being victim of internal fraud

\begin{tabular}{|c|c|c|c|c|c|}
\hline & Value & DF & $\begin{array}{c}\text { Asymp. Sig. } \\
\text { (2-sided) }\end{array}$ & $\begin{array}{c}\text { Exact Sig. } \\
\text { (2-sided) }\end{array}$ & $\begin{array}{l}\text { Exact Sig. } \\
\text { (1-sided) }\end{array}$ \\
\hline Pearson Chi-Square & $3.255^{\mathrm{a}}$ & 1 & 0.071 & & \\
\hline Continuity Correction $^{b}$ & 2.322 & 1 & 0.128 & & \\
\hline Likelihood Ratio & 3.451 & 1 & 0.063 & & \\
\hline Fisher's Exact Test & & & & 0.095 & 0.061 \\
\hline $\begin{array}{l}\text { Linear-by-Linear } \\
\text { Association }\end{array}$ & 3.204 & 1 & 0.073 & & \\
\hline \# of valid cases & 64 & & & & \\
\hline
\end{tabular}

Significance Level (observed) $=0.095$ (Fisher's exact test) $($ Table 82)

Significance Level $($ chosen $)=0.05$

Significance level of Fisher's exact test is 0.095 which is less than the chosen level of 0.05 .

\section{Result 18:}

There is not enough evidence to reject $\mathrm{H}_{0}$ hypothesis on the 0.05 significance level.

\section{Correlation Analysis 19}

$\mathbf{H}_{\mathbf{0}}$ : There is no significant association between considering "giving presents to the employers" is acceptable for the survival of a company and the likelihood of being a victim of any kind of fraud. 
Table 83: Contingency table of bribe employers for the survival of the Company and being victim of internal fraud

\begin{tabular}{|c|c|c|c|c|c|}
\hline & & & $\begin{array}{r}\text { Has your cor } \\
\text { victim of a } \\
\text { internal frau } \\
\text { three y }\end{array}$ & $\begin{array}{l}\text { any been } \\
\text { sort of } \\
\text { n the last } \\
\text { rs? }\end{array}$ & Total \\
\hline & & & Yes (1) & No (2) & \\
\hline Is giving presents to & Yes & $\mathrm{OV}$ & 18 & 2 & م \\
\hline employers acceptable & (1) & $\mathrm{EV}$ & 13.1 & 6.9 & \\
\hline for the survival of your & No & OV & 24 & 20 & 44 \\
\hline company? & (2) & EV & 28.9 & 15.1 & 4 \\
\hline Total & & & 42 & 22 & 64 \\
\hline
\end{tabular}

Table 84: Chi Square tests for correlation between giving presents to employers for the survival of the Company and being victim of internal fraud

\begin{tabular}{|c|c|c|c|c|c|}
\hline & Value & DF & $\begin{array}{c}\text { Asymp. Sig. } \\
\text { (2-sided) }\end{array}$ & $\begin{array}{l}\text { Exact Sig. } \\
\text { (2-sided) }\end{array}$ & $\begin{array}{c}\text { Exact Sig. } \\
\text { (1-sided) }\end{array}$ \\
\hline Pearson Chi-Square & $7.662^{\mathrm{a}}$ & 1 & 0.006 & & \\
\hline Continuity Correction $^{b}$ & 6.171 & 1 & 0.013 & & \\
\hline Likelihood Ratio & 8.731 & 1 & 0.003 & & \\
\hline Fisher's Exact Test & & & & 0.009 & 0.005 \\
\hline $\begin{array}{l}\text { Linear-by-Linear } \\
\text { Association }\end{array}$ & 7.542 & 1 & 0.006 & & \\
\hline \# of valid cases & 64 & & & & \\
\hline
\end{tabular}

a. 0 cells $(, 0 \%)$ have expected count less than 5 . The minimum expected count is 7.22.

b. Computed only for a $2 \times 2$ table

Significance Level $($ observed $)=0.009$ (Fisher's exact test) $($ Table 84$)$

Significance Level $($ chosen $)=0.05$ 
Significance level of Fisher's exact test is 0.015 which is less than the chosen level of 0.05. Therefore, there is enough evidence to reject $\mathrm{H}_{0}$ on the 0.05 significance level. It means that there is an association between giving presents to the employers in order to maintain the existence of a company acceptable and the likelihood of the Company being a victim of any kind of fraud.

In order to identify the degree of association between the variables, Kendall-tau tests are applied. Below table shows the results of Kendall-tau tests.

Table 85: Kendall-tau tests for giving presents to employers for the survival of the Company and being victim of internal fraud

\begin{tabular}{|c|c|c|c|c|}
\hline & Value & Asymp. Std. Error ${ }^{a}$ & Approx. $\mathbf{T}^{\mathrm{b}}$ & Approx. Sig. \\
\hline Kendall's tau-b & 0.346 & 0.096 & 3.318 & 0.001 \\
\hline Kendall's tau-c & 0.305 & 0.092 & 3.318 & 0.001 \\
\hline \# of valid cases & 64 & & & \\
\hline
\end{tabular}

In this case, Kendall-tau-b coefficient is used since the contingency table is square shaped. Kendall-tau-b coefficient is 0.346 and the significance level of Kendalltau-b coefficient is 0.001 which is less than the significance level of 0.05 . Therefore, on the 0.05 significance level, there is a positive association between the variables.

\section{Result 19:}

The companies which consider giving presents to the employers in order to maintain the existence of a company is acceptable are more likely to experience fraud. 


\section{Correlation Analysis 20}

$\mathbf{H}_{\mathbf{0}}$ : There is no significant association between considering "bribing employers is acceptable for the survival of a company" is acceptable and the likelihood of a company being a victim of any kind of fraud.

Table 86: Contingency table of bribing employers for the survival of the Company and being victim of internal fraud

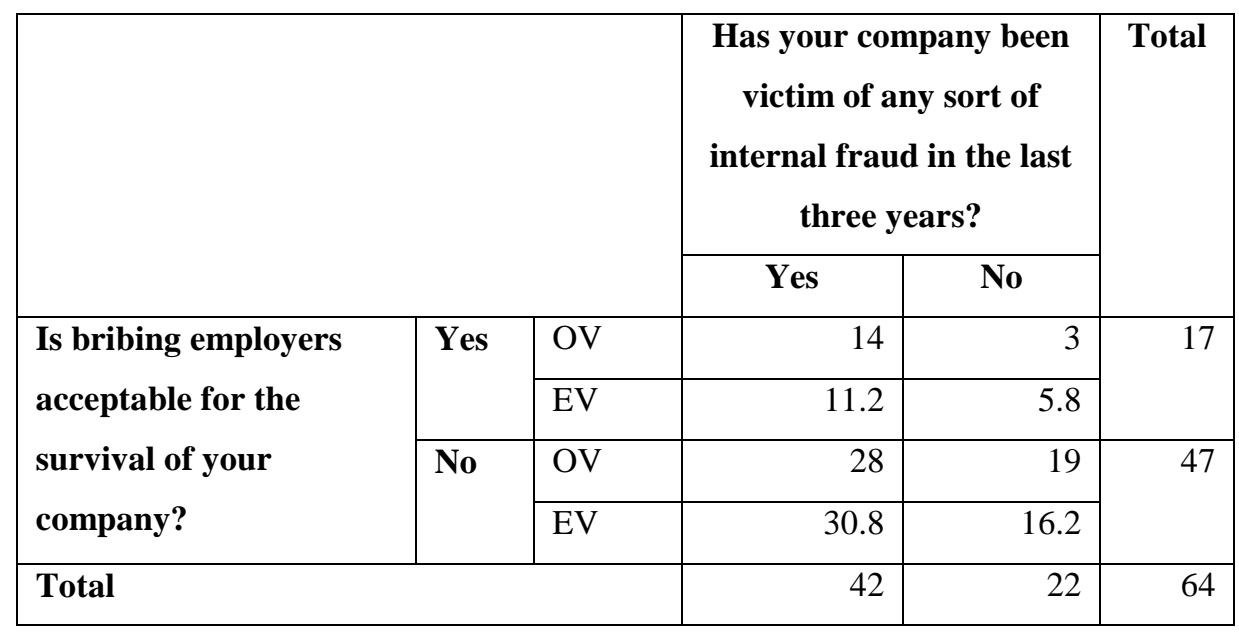

Table 87: Chi Square tests for correlation bribing employers for the survival of the Company and being victim of internal fraud

\begin{tabular}{|l|r|r|r|r|r|}
\hline & Value & DF & $\begin{array}{c}\text { Esymp. Sig. } \\
\text { (2-sided) }\end{array}$ & $\begin{array}{r}\text { Exact } \\
\text { Exig. } \\
\text { (2-sided) }\end{array}$ & $\begin{array}{r}\text { Sig. (1- } \\
\text { sided) }\end{array}$ \\
\hline Pearson Chi-Square & $2.871^{\mathrm{a}}$ & 1 & 0.090 & & \\
\hline Continuity Correction $^{\text {b }}$ & 1.950 & 1 & 0.163 & & \\
\hline Likelihood Ratio & 3.101 & 1 & 0.078 & & 0.137 \\
\hline Fisher's Exact Test & & & & & \\
\hline Linear-by-Linear Association & 2.827 & 1 & 0.093 & & \\
\hline \# of valid cases & 64 & & & & \\
\hline
\end{tabular}

a. 0 cells $(, 0 \%)$ have expected count less than 5 . The minimum expected count is 5.84 .

b. Computed only for a $2 \times 2$ table 
Significance Level $($ observed $)=0.137$ (Fisher's exact test) $($ Table 87$)$

Significance Level $($ chosen $)=0.05$

Significance level of Fisher's exact test is 0.137 which is greater than the chosen level of 0.05 .

\section{Result 20:}

There is not enough evidence to reject $\mathrm{H}_{0}$ hypothesis on the 0.05 significance level.

\section{Correlation Analysis 21}

$\mathbf{H}_{\mathbf{0}}$ : There is no significant association between permitting/encouraging facilitation payments and likelihood of being a victim of "misuse of inventory" fraud for a company.

Table 88: Contingency table of permitting/encouraging facilitation payments and being victim of "Misuse of an Inventory"

\begin{tabular}{|c|c|c|c|c|c|}
\hline & \multicolumn{2}{|c|}{$\begin{array}{c}\text { Did "misuse of an } \\
\text { inventory" happen in your } \\
\text { company? }\end{array}$} & \multirow[t]{2}{*}{ Total } \\
\hline & & & Yes (1) & No (2) & \\
\hline \multirow{4}{*}{$\begin{array}{l}\text { Does your company } \\
\text { permit/encourage } \\
\text { facilitation payments? }\end{array}$} & \multirow{2}{*}{$\begin{array}{l}\text { Yes } \\
\text { (1) }\end{array}$} & OV & 11 & 17 & \multirow{2}{*}{28} \\
\hline & & EV & 7.7 & 20.3 & \\
\hline & \multirow{2}{*}{$\begin{array}{l}\text { No } \\
\text { (2) }\end{array}$} & $\mathrm{OV}$ & 2 & 17 & \multirow{2}{*}{19} \\
\hline & & EV & 5.3 & 13.7 & \\
\hline \multicolumn{3}{|l|}{ Total } & 13 & 34 & 47 \\
\hline
\end{tabular}


Table 89: Chi Square tests for correlation permitting/encouraging facilitation payments and being victim of "Misuse of an Inventory"

\begin{tabular}{|c|c|c|c|c|c|}
\hline & Value & DF & $\begin{array}{c}\text { Asymp. Sig. } \\
\text { (2-sided) }\end{array}$ & $\begin{array}{l}\text { Exact Sig. } \\
\text { (2-sided) }\end{array}$ & $\begin{array}{l}\text { Exact Sig. } \\
\text { (1-sided) }\end{array}$ \\
\hline Pearson Chi-Square & $4.679^{\mathrm{a}}$ & 1 & 0.031 & & \\
\hline Continuity Correction ${ }^{b}$ & 3.352 & 1 & 0.067 & & \\
\hline Likelihood Ratio & 5.125 & 1 & 0.024 & & \\
\hline Fisher's Exact Test & & & & 0.046 & 0.030 \\
\hline Linear-by-Linear Association & 4.579 & 1 & 0.032 & & \\
\hline \# of valid cases & 47 & & & & \\
\hline
\end{tabular}

Significance Level $($ observed $)=0.046$ (Fisher's exact test $)($ Table 89$)$

Significance Level $($ chosen $)=0.05$

Significance level of Fisher's exact test is 0.046 which is less than the chosen level of 0.05 . Therefore, there is enough evidence to reject $\mathrm{H}_{0}$ on the 0.05 significance level. It means that there is an association between permitting/encouraging facilitation payments and experiencing "misuse of inventory" fraud.

In order to identify the degree of association between variables, Kendall-tau tests are applied. Below table shows the results of Kendall-tau tests. 
Table 90: Kendall-tau tests for permitting/encouraging facilitation payments and being victim of "Misuse of an Inventory"

\begin{tabular}{|c|c|c|c|c|}
\hline & Value & Asymp. Std. Error ${ }^{a}$ & Approx. $T^{b}$ & Approx. Sig. \\
\hline Kendall's tau-b & 0.316 & 0.121 & 2.453 & $\overline{0.014}$ \\
\hline Kendall's tau-c & 0.277 & 0.113 & 2.453 & 0.014 \\
\hline \# of valid cases & 47 & & & \\
\hline
\end{tabular}

In this case, Kendall-tau-b coefficient is used since the contingency table is square shaped. Kendall-tau-b coefficient is 0.316 and the significance level of Kendalltau-b coefficient is 0.014 which is less than the significance level of 0.05 . Therefore, on the 0.05 significance level, there is a positive association between the variables.

Result 21:

The companies which permit/encourage facilitation payments are more likely to experience "misuse of inventory" fraud.

\section{Correlation Analysis 22}

$\mathbf{H}_{0}$ : There is no significant association between permitting/encouraging facilitation payments and likelihood of being a victim of "cash theft" fraud. 
Table 91: Contingency table of permitting/encouraging facilitation payments and being victim of "Cash Theft"

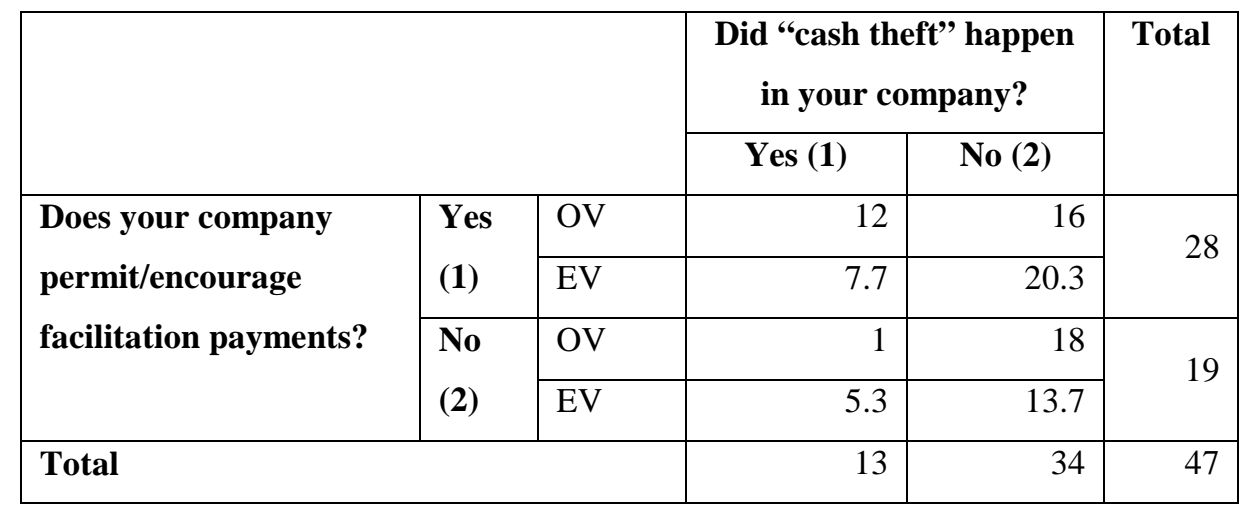

Table 92: Chi Square tests for correlation between permitting/encouraging facilitation payments and being victim of "Cash Theft"

\begin{tabular}{|l|r|r|r|r|r|}
\hline & Value & DF & $\begin{array}{c}\text { Asymp. Sig. } \\
\text { (2-sided) }\end{array}$ & $\begin{array}{c}\text { Exact Sig. } \\
\text { (2-sided) }\end{array}$ & $\begin{array}{c}\text { Exact Sig. } \\
\text { (1-sided) }\end{array}$ \\
\hline Pearson Chi-Square & $7.995^{\mathrm{a}}$ & 1 & 0.005 & & \\
\hline Continuity Correction & & & & & \\
\hline Likelihood Ratio & 6.227 & 1 & 0.013 & & \\
\hline Fisher's Exact Test & 9.355 & 1 & 0.002 & & \\
\hline $\begin{array}{l}\text { Linear-by-Linear } \\
\text { Association }\end{array}$ & 7.825 & 1 & 0.005 & & \\
\hline \# of valid cases & 47 & & & & \\
\hline
\end{tabular}

a. 0 cells $(, 0 \%)$ have expected count less than 5 . The minimum expected count is 5.26.

b. Computed only for a $2 \times 2$ table

Significance Level (observed) $=0.007$ (Fisher's exact test) $($ Table 92)

Significance Level $($ chosen $)=0.05$

Significance level of Fisher's exact test is 0.007 which is less than the chosen level of 0.05 . Therefore, there is enough evidence to reject $\mathrm{H}_{0}$ on the 0.05 
significance level. It means that there is an association between permitting/encouraging facilitation payments and experiencing cash theft.

In order to identify the degree of association between variables, Kendall-tau tests are applied. Below table shows the results of Kendall-tau tests.

Table 93: Kendall-tau tests for permitting/encouraging facilitation payments and being victim of "Cash Theft"

\begin{tabular}{|c|c|c|c|c|}
\hline & Value & Asymp. Std. Error ${ }^{a}$ & Approx. $\mathbf{T}^{\mathrm{b}}$ & Approx. Sig. \\
\hline Kendall's tau-b & 0.412 & 0.104 & 3.457 & 0.001 \\
\hline Kendall's tau-c & 0.362 & 0.105 & 3.457 & $\overline{0.001}$ \\
\hline \# of valid cases & 47 & & & \\
\hline
\end{tabular}

In this case, Kendall-tau-b coefficient is used since the contingency table is square. Kendall-tau-b coefficient is 0.412 and the significance level of Kendalltau-b coefficient is 0.001 which is less than the significance level of 0.05 . Therefore, on the 0.05 significance level, there is a positive association between the variables.

$\underline{\text { Result 22: }}$

The companies which permit/encourage facilitation payments are more likely to experience cash theft.

\subsection{Correlation Analysis Summary}

Summary of the results of correlation analysis are depicted in the following table: 
Table 94: Correlation analysis summary

\begin{tabular}{|c|c|c|c|c|c|}
\hline & $\begin{array}{l}\text { Independent } \\
\text { variable }\end{array}$ & $\begin{array}{l}\text { Dependent } \\
\text { variable }\end{array}$ & $\begin{array}{l}\text { Result } \\
\text { (on 5\% significance level) }\end{array}$ & $\begin{array}{l}\text { Kendall's } \\
\text { tau-b }\end{array}$ & $\begin{array}{l}\text { Kendall's } \\
\text { tau-c }\end{array}$ \\
\hline 1 & $\begin{array}{l}\text { Performing } \\
\text { projects } \\
\text { abroad }\end{array}$ & $\begin{array}{l}\text { Thinking } \\
\text { the } \\
\text { company is } \\
\text { under the } \\
\text { risk of fraud }\end{array}$ & $\begin{array}{l}\text { Respondents working for } \\
\text { construction companies } \\
\text { which perform projects } \\
\text { abroad do not think that their } \\
\text { company is under the risk of } \\
\text { fraud. }\end{array}$ & N/A & N/A \\
\hline 2 & $\begin{array}{l}\text { Annual } \\
\text { revenue }\end{array}$ & $\begin{array}{l}\text { Having code } \\
\text { of business } \\
\text { conduct }\end{array}$ & $\begin{array}{l}\text { The higher the company } \\
\text { revenue, the more likely is } \\
\text { that the company has code } \\
\text { of business conduct }\end{array}$ & N/A & 0.336 \\
\hline 3 & $\begin{array}{l}\text { Number of } \\
\text { employees }\end{array}$ & $\begin{array}{l}\text { Having code } \\
\text { of business } \\
\text { conduct }\end{array}$ & $\begin{array}{l}\text { The higher the number of } \\
\text { employees is working at } \\
\text { central offices, the more } \\
\text { likely it is that a company } \\
\text { has code of business conduct }\end{array}$ & N/A & 0.375 \\
\hline 4 & $\begin{array}{l}\text { Number of } \\
\text { employees }\end{array}$ & $\begin{array}{l}\text { Getting } \\
\text { external } \\
\text { audit } \\
\text { services }\end{array}$ & $\begin{array}{l}\text { The higher the number of } \\
\text { employees, the more likely it } \\
\text { is for the company to get } \\
\text { internal audit services }\end{array}$ & N/A & 0.373 \\
\hline 5 & $\begin{array}{l}\text { Annual } \\
\text { revenue }\end{array}$ & $\begin{array}{l}\text { Having an } \\
\text { internal } \\
\text { audit } \\
\text { function }\end{array}$ & $\begin{array}{l}\text { The higher the company } \\
\text { revenue, the more likely it is } \\
\text { for the company to get } \\
\text { external audit services }\end{array}$ & N/A & 0.295 \\
\hline 6 & $\begin{array}{l}\text { Number of } \\
\text { employees }\end{array}$ & $\begin{array}{l}\text { Having a list } \\
\text { of } \\
\text { qualified/sel } \\
\text { ected } \\
\text { vendors }\end{array}$ & $\begin{array}{l}\text { The higher the number of } \\
\text { employees works at the } \\
\text { central office of the } \\
\text { company, the more likely it } \\
\text { will be for the company to } \\
\text { have a qualified/selected } \\
\text { vendor list }\end{array}$ & N/A & 0.242 \\
\hline
\end{tabular}


Table 94: Correlation analysis summary (continued)

\begin{tabular}{|c|c|c|c|c|c|}
\hline 7 & $\begin{array}{l}\text { Annual } \\
\text { revenue }\end{array}$ & $\begin{array}{l}\text { Having a list of } \\
\text { qualified/selected } \\
\text { vendors }\end{array}$ & $\begin{array}{l}\text { The higher the company } \\
\text { revenue, the more likely it will } \\
\text { be for the company to have } \\
\text { qualified/selected vendor lists }\end{array}$ & N/A & 0.231 \\
\hline 8 & $\begin{array}{l}\text { Annual } \\
\text { revenue }\end{array}$ & $\begin{array}{l}\text { Having } \\
\text { requirement to } \\
\text { obtain bids from } \\
\text { multiple vendors }\end{array}$ & $\begin{array}{l}\text { The higher the company } \\
\text { revenue, the more likely it will } \\
\text { be for the company to have } \\
\text { requirements to obtain bids } \\
\text { from multiple vendors }\end{array}$ & N/A & 0.235 \\
\hline 9 & $\begin{array}{l}\text { Number of } \\
\text { employees }\end{array}$ & $\begin{array}{l}\text { Having segregated } \\
\text { purchase order and } \\
\text { vendor selection } \\
\text { functions }\end{array}$ & $\begin{array}{l}\text { The higher the number of } \\
\text { employees, the more likely it } \\
\text { will be for the company to } \\
\text { segregate purchase order and } \\
\text { vendor selection functions }\end{array}$ & N/A & 0.288 \\
\hline 10 & $\begin{array}{l}\text { Number of } \\
\text { employees }\end{array}$ & $\begin{array}{l}\text { Verifying } \\
\text { education and } \\
\text { certificate } \\
\text { information of job } \\
\text { applicants }\end{array}$ & $\begin{array}{l}\text { The higher the number of } \\
\text { employees, the more likely it } \\
\text { will be for the company to } \\
\text { verify education/certificate } \\
\text { information of job applicants }\end{array}$ & N/A & 0.205 \\
\hline 11 & $\begin{array}{l}\text { Internal Fraud } \\
\text { Occurred }\end{array}$ & $\begin{array}{l}\text { Thinking the } \\
\text { company is under } \\
\text { the risk of fraud }\end{array}$ & $\begin{array}{l}\text { The respondents who } \\
\text { experienced fraud case are more } \\
\text { likely to believe that the } \\
\text { company is under the risk of } \\
\text { fraud }\end{array}$ & 0.646 & N/A \\
\hline 12 & $\begin{array}{l}\text { Annual } \\
\text { revenue }\end{array}$ & $\begin{array}{l}\text { Internal Fraud } \\
\text { Occurred }\end{array}$ & No relationship identified & N/A & N/A \\
\hline 13 & $\begin{array}{l}\text { Number of } \\
\text { expertise areas }\end{array}$ & $\begin{array}{l}\text { Internal Fraud } \\
\text { Occurred }\end{array}$ & No relationship identified & N/A & N/A \\
\hline 14 & $\begin{array}{l}\text { Performing } \\
\text { projects } \\
\text { abroad }\end{array}$ & $\begin{array}{l}\text { Internal Fraud } \\
\text { Occurred }\end{array}$ & No relationship identified & N/A & N/A \\
\hline 15 & $\begin{array}{l}\text { Having an } \\
\text { internal audit } \\
\text { function }\end{array}$ & $\begin{array}{l}\text { Internal Fraud } \\
\text { Occurred }\end{array}$ & No relationship identified & N/A & N/A \\
\hline
\end{tabular}


Table 94: Correlation analysis summary (continued)

\begin{tabular}{|c|c|c|c|c|c|}
\hline 16 & $\begin{array}{l}\text { Checking the references } \\
\text { of job applicants }\end{array}$ & $\begin{array}{l}\text { Internal } \\
\text { Fraud } \\
\text { Occurred }\end{array}$ & $\begin{array}{l}\text { The companies that check the } \\
\text { references of job applicants are } \\
\text { less likely to experience fraud }\end{array}$ & 0.298 & N/A \\
\hline 17 & $\begin{array}{l}\text { Permitting/encouraging } \\
\text { facilitation payments }\end{array}$ & $\begin{array}{l}\text { Internal } \\
\text { Fraud } \\
\text { Occurred }\end{array}$ & $\begin{array}{l}\text { The companies which } \\
\text { permit/encourage facilitation } \\
\text { payments are more likely to } \\
\text { experience fraud }\end{array}$ & 0.364 & N/A \\
\hline 18 & $\begin{array}{l}\text { Thinking "organizing } \\
\text { entertainments for } \\
\text { employers is acceptable } \\
\text { for the survival of the } \\
\text { company" }\end{array}$ & $\begin{array}{l}\text { Internal } \\
\text { Fraud } \\
\text { Occurred }\end{array}$ & No relationship identified & N/A & N/A \\
\hline 19 & $\begin{array}{l}\text { Thinking "giving } \\
\text { presents to employers is } \\
\text { acceptable for the } \\
\text { survival of the } \\
\text { company" }\end{array}$ & $\begin{array}{l}\text { Internal } \\
\text { Fraud } \\
\text { Occurred }\end{array}$ & $\begin{array}{l}\text { The companies which consider } \\
\text { giving presents to the employers } \\
\text { in order to maintain the } \\
\text { existence of a company is } \\
\text { acceptable are more likely to } \\
\text { experience fraud }\end{array}$ & 0.346 & N/A \\
\hline 20 & $\begin{array}{l}\text { Thinking "bribing } \\
\text { employers is acceptable } \\
\text { for the survival of the } \\
\text { company" }\end{array}$ & $\begin{array}{l}\text { Internal } \\
\text { Fraud } \\
\text { Occurred }\end{array}$ & No relationship identified & N/A & N/A \\
\hline 21 & $\begin{array}{l}\text { Permitting/encouraging } \\
\text { facilitation payments }\end{array}$ & $\begin{array}{l}\text { Internal } \\
\text { Fraud, } \\
\text { "misuse } \\
\text { of } \\
\text { inventory } \\
" \\
\text { occurred }\end{array}$ & $\begin{array}{l}\text { The companies which } \\
\text { permit/encourage facilitation } \\
\text { payments are more likely to } \\
\text { experience "misuse of } \\
\text { inventory" fraud }\end{array}$ & 0.316 & N/A \\
\hline 22 & $\begin{array}{l}\text { Permitting/encouraging } \\
\text { facilitation payments }\end{array}$ & $\begin{array}{l}\text { Internal } \\
\text { Fraud, } \\
\text { "cash } \\
\text { theft" } \\
\text { occurred }\end{array}$ & $\begin{array}{l}\text { The companies which } \\
\text { permit/encourage facilitation } \\
\text { payments are more likely to } \\
\text { experience cash theft }\end{array}$ & 0.412 & N/A \\
\hline
\end{tabular}




\section{CHAPTER 6}

\section{RECOMMENDATION TO CONSTRUCTION PROFESSIONALS}

The survey revealed that there are some improvement opportunities which should be considered by construction professionals in order to mitigate internal fraud risks. Main improvement opportunities are explained below:

\section{Setting an Efficient Governance Structure}

Setting an efficient governance structure is one of the important steps to mitigate fraud risks. However, according to survey results less than $40 \%$ of the respondents stated that the companies that they are working for have code of business conducts and also less than $20 \%$ of them mentioned that they have internal trainings about fraud awareness, ethical rules and etc., in place.

However, governance should be established by providing written workflows, job descriptions, clear organizational structure, comprehensive policies and procedures to reduce the likelihood of internal fraud.

Implementing Effective Internal Controls and Periodic Fraud Risk Assessments

Internal controls should be implemented to ensure the effectiveness and efficiencies of operations and their compliance with laws and regulations.

Almost $60 \%$ of the respondents stated that the companies they are working for try to obey segregation of duties principle during vendor selection and purchase 
processes and also likelihood of obeying the principle increases when the number of employees and revenues increase. However, all of the companies should try to be in compliance with segregation of duties principle in vendor selection and purchase processes regardless its size and number of employees.

Survey results showed that past employment verification is the most common method applied by the companies before hiring employees. However, education verification and criminal conviction checks should also be established as preventive measures to mitigate fraud risks. Moreover, survey results also revealed that likelihood of applying employee background checks directly related with the size of the companies. However, background checks should be performed by the companies regardless its size.

More than half of the respondents stated that fraud risk assessment had never performed fraud risk assessment. However, periodical fraud risks should be performed to identify fraud risks and put controls to prevent those risks.

\section{Internal and External Audits}

Implementation of an independent internal and external audit program would help identifying new vulnerabilities, and measure the effectiveness of existing controls.

\section{Training of Employees}

Employees should be trained about policies and procedures related to fraud, internal controls, code of conduct and ethic policies. 


\section{Establishing a Whistleblower Hotline}

Whistleblower hotlines provide a confidential way of reporting for employees and they benefits had been proven. However, survey results showed that they are used by only less than $10 \%$ of the companies.

To be informed anonymously about vendor and customer related violations of policies and procedures, companies should establish whistleblower hotlines. 


\section{CHAPTER 7}

\section{CONCLUSION}

Construction companies face more challenges in dealing with the problem of internal fraud and corruption compared to the companies operating in other sectors due to the nature of construction works. However, dealing with this problem is now an easy process as it needs extra time and resources.

In order to understand fraud awareness level of Turkish construction contractors companies, a survey was applied to them. In the survey, the questions are related to three main areas. One of them is the proactive measures of the construction companies to prevent fraud, the other one is the common fraud types that the construction companies experience and the last one is the reactions of the construction companies after experiencing internal fraud incidents.

Almost half of the respondents stated that the companies that they are working for experience internal fraud cases. The most common ways of internal fraud are receiving fictitious invoices for goods or services, inflating invoices, reimbursement of fictitious or inflated business expenses by an employee, kickbacks/bribes taken by employees and cash theft.

Around $40 \%$ of the survey respondents believe that the companies which they are working for are under internal fraud risk. Besides, correlation analysis showed that the ones who already experienced an internal fraud incident or working for the construction companies which are doing construction projects abroad are more likely to believe that the company is under internal fraud risk. 
More than half of the respondents believe the importance of internal audit, external audit and implementation of segregation of duties principle to prevent fraud. Despite the fact that reports published by ACFE demonstrated the importance of encouragement and protection of whistleblowers and whistleblowing hotlines to prevent fraud, most of the respondents do not mention the importance of such services.

According to the respondents, fictitious invoices received for goods or services, inflated invoices, kickbacks/bribes taken by employee and bid rigging are the most likely ways of internal fraud in construction business. Inventory theft, cash theft, falsified working hours and ghost employee are mentioned as the less likely types of internal fraud.

Survey results show that more than half of the companies did not perform fraud risk assessment. Moreover, only internal audit is used as a fraud prevention method by more than half of the companies. Other preventive measures such as legal counsel, internal trainings, periodical legal due diligence and whistleblowing hotlines are used by only a small portion of the companies. Correlation tests show that the companies having internal audit functions are less likely to experience internal fraud incidents.

Noteworthy amount of companies, especially the ones which have higher revenues and number of employees, have developed structures for vendor selection procedures. It is observed that the methods such as using different parties for purchase order and invoice approval, obtaining bids from multiple vendors, having a list of qualified/selected vendors and using different parties for purchase order and vendor selection are used by most of the companies.

For employee selection procedures, it is observed that the construction companies mostly focus on past employment verifications and reference verifications. However, criminal conviction checks and education and certificate verifications 
are not common procedures. As a result of survey, it is noted that the companies checking the references of job applicants are less likely to experience fraud.

Considerable amount of respondents stated that they can rationalize giving presents to clients, organization of entertainments for clients, misrepresenting financial status of the company and making payments to clients if they believe the companies that they are working for has a survival risk. However, it is monitored that the companies are more likely to experience internal fraud incidences if the culture of the company permits to rationalize wrong actions for the survival of the company.

Facilitation payments could be another example for wrongdoings. Although facilitation payments comprise major corruption risks, nearly half of the construction companies permit facilitation payments. It is observed that the companies which show tolerance to facilitation payments and permit them are more likely to experience internal fraud incidences. According to the Kendal Tau tests, the fraud types, misuse of inventory and cash theft, are more likely to occur in companies which permit and encourage facilitation payments. 


\section{REFERENCES}

American Institute of Certified Public Accountants, Statement on Auditing Standards No: 99: Consideration of Fraud in a Financial Statement Audit. (2002).

Argandoña, A. (2005). Corruption and companies: the use of facilitating payments. Journal of Business Ethics, 60(3), p.251-264.

Asia Pacific Economic Cooperation (2007). APEC anti-corruption code of conduct for business. Retrieved from <http://www.apec.org/Groups/SOMSteering-Committee-on-Economic-and-Technical-Cooperation/Task-

Groups/ /media/Files/Groups/ACT/07_act_codebrochure.ashx> on 24 March 2011.

Association of Certified Fraud Examiners (2010). 2010 Report to the Nations on Occupational fraud and Abuse. Retrieved from <http://www.acfe.com/rttn/rttn2010.pdf > on 11 March 2011.

Association of Certified Fraud Examiners, Inc (2008). Fraud Examiners Manual.

Bayar, G. (June 2003). Corruption-A game theoretical analysis (Doctoral Thesis). Middle East Technical University.

Bierstaker, J. L., Brody, R. G., Pacini, C. (2006). Accountants' perceptions regarding fraud detection and prevention methods. Managerial Auditing Journal, $21(5)$, pp. $520-535$.

Cendrowski, H; Petro, L.W; Martin, J.P. (2007). The Handbook of Fraud Deterrence, $2^{\text {nd }}$ edition. John Willey and Sons Inc..

Chernoff H., Lehmann E.L. (1954), "The use of maximum likelihood estimates in $\chi^{2}$ tests for goodness-of-fit", The Annals of Mathematical statistics (25), pp.579586 
Coenen, T. (2008). Essential of Corporate Fraud, John Wiley and Sons, Inc., New York.

“corruption” Black, J., Hashimzade, N., and Myles, G. (2009). A dictionary of economics. Oxford University Press, Retrieved from<http://www.oxfordreference.com/views/ENTRY.html?subview=Main\&entr $\mathrm{y}=\mathrm{t} 19 . \mathrm{e} 606>$ on 24 March 2011.

Durant, A. (October/November 2005). The enemy within. Engineering Management, 15(5), p.30-33.

Engeli, G. and Pieth, M. (2000). Developing an integrity programme for FIDIC: a private sector initiative to prevent corruption in IFI-funded public procurement, Background Paper, commissioned by the World Bank and prepared for the Annual Meeting of FIDIC 2000 in Honolulu.

Ergün, G.O. (2007). Anti-Corruption Legislation In Turkish Law. German Law Journal. 8(9), p.903 - 914.

Ernst and Young (2010). 11 ${ }^{\text {th }}$ global fraud survey. Retrieved from <http://www.ey.com/Publication/vwLUAssets/EY_11th_GLOBAL_FRAUD_Sur vey/\$FILE/EY_11th_GLOBAL_FRAUD_Survey.pdf> on 11 March 2011

Ersnt and Young. (2009). Detecting financial statement fraud: What every manager needs to know. Retrieved from $<$ https://webforms.ey.com/Publication/vwLUAssets/FIDS-

FI_DetectingFinancialStatementFraud.pdf/\$FILE/FIDS-

FI_DetectingFinancialStatementFraud.pdf> on 10 March 2011.

Ernst and Young (2009). European fraud survey. Retrieved from <http://www2.eycom.ch/publications/items/fraud_eu_2009/200904_EY_Europea n_Fraud_Survey.pdf> on 11 March 2011.

Farragher G.P. and Nelder S.M. (March 2001). Construction fraud: The cost of doing business?. CPA Construction Niche Builder 22(3).

Fisher, R.A. (1954). Statistical Methods for Research Workers. Oliver and Boyd. 
"fraud" Ed Jonathan Law and John Smullen (2008).A dictionary of finance and banking. Oxford University Press. Retrieved from

<http://www.oxfordreference.com/views/ENTRY.html?subview=Main\&entry=t2

$0 . e 1513>$ on 8 March 2011

G 8 Countries (2005). Glenagles Comminique. Retrieved from

<http://www.unglobalcompact.org/docs/about_the_gc/government_support/PostG 8_Gleneagles_Communique.pdf> on 24 March 2011.

Green, B., Calderon, T. (1996). Information privity and the internal auditor's assessment of fraud risk factors. Internal Auditing, 11(4), pp 4-15.

Gupta, A.K., Govindarajan, V. (1991). Knowledge flows and the structure of control within multinational corporations. Academy of Management Review 16(4): pp 768-792.

Hartley, R. (2009). Fighting corruption in the Australian construction industry: the national code of practice. Leadership and Management in Engineering 9(3), p.131-135.

Hauserman, N. R. (March/April 1986). Whistle-blowing: individual morality in a corporate society. Business Horizons, Mar/Apr86, Vol. 29 Issue 2, p4, 6p

Henry, W. (2009). Addressing corruption in our engineering/construction industry. Leadership and Management in Engineering 9(3): p. 101-102

"internal auditing" The Institute of Internal Auditors. Retrieved from <http://www.theiia.org/theiia/about-the-profession/internal-audit-faqs/?i=1077> on 11 March 2011

International Accounting Standards Board. (Effective for audits of financial statements for periods beginning on or after 15 December 2009). International standard on auditing 240: The auditor's responsibilities relating to fraud in an audit of financial statements. Retrieved from <http://web.ifac.org/download/a0122010-iaasb-handbook-isa-240.pdf> on 11 March 2011. 
International Federation of Consulting Engineers, Code of Ethics. Retrieved from $<$ http://www1.fidic.org/about/ethics.pdf> on 10 March 2011.

Jong, M., Henry, W. and Stansbury, N. (2009). Eliminating corruption in our engineering/construction industry. Leadership and Management in Engineering 9(3): p. 105-111

Kendall, M.G. (1955). Correlation Methods. John Wiley and Sons Ltd., London

KPMG (2005). Global construction survey 2005: Risk taker, profit maker?.

Retrieved from

<http://us.kpmg.com/microsite/attachments/2005/Global_Construction_Survey_2 005.pdf> on 11 March 2011.

KPMG (2010). Global construction survey 2010. Retrieved from < http://www.kpmg.com/US/en/IssuesandInsights/ArticlesPublications/Documents/ kpmg-global-construction-survey-2010.pdf> on 11 March 2011.

Krishnan, C. (2009). Eliminating corruption in our engineering/construction industry. Leadership and Management in Engineering 9(3): p. 112-114

Kroll (2010). Global fraud report. Retrieved from <http://www.kroll.com/library/fraud/FraudReport_English-US_Oct10.pdf> on 11 March 2011.

Kruskal, W.H. (1958), "Ordinal Measures of Association”, Journal of the American Statistical Association, 53(284), pp.814-861

Lou, Y.I., and Wang, M.L. (2009). Fraud risk factor of the fraud triangle assessing the likelihood of fraudulent financial reporting. Journal of Business and Economics Research, 7(2), p.61-78.

Melgar, N., Rossi, M. and Smith, T. (2009). The perception of corruption. International Journal of Public Opinion Research 
“misappropriation” Black, H. C. (1979). Black's law dictionary, 5th edition, St. Paul, Minesota, West Publishing Co., pp. 901.

Murdock, H. (2008). The three dimensions of fraud: auditors should understand the needs, opportunities, and justifications that lead individuals to. Retrieved from < http://www.entrepreneur.com/tradejournals/article/183444845.html> on 11 March 2011

OECD, Directorate For Financial and Enterprise Affairs. (November 2004). Turkey: phase 1: Review of implementation of the convention and 1997 recommendation. Retrieved from <http://www.dtm.gov.tr/dtmadmin/upload/ANL/CokTarafliAnlasmaDb/rusvet/biri nci_inceleme_raporu_ing.pdf $>$ on 11 March 2011

OECD (Adopted by the Negotiating Conference on 21 November 1997). Convention on Combating Bribery of Foreign Public Officials in International Business Transactions. Retrieved from <http://www.oecd.org/dataoecd/4/18/38028044.pdf> on 11 March 2011.

Pricewaterhousecoopers (2010). Engineering and construction sector summary, Global Economic Crime Survey. Retrieved from <http://www.pwc.com/en_GX/gx/engineering-construction/fraud-economiccrime/pdf/global-economic-crime-survey-2009.pdf> on 11 March 2011.

Ravishankar, L. (2010). Encouraging Internal Whistleblowing in Organizations. Retrieved from <http://www.scu.edu/ethics/publications/submitted/whistleblowing.html > on 8 March 2011

Republic of Turkey Ministry of Finance Financial Crimes Investigation Board. (2008). Türkiye'de Yolsuzlukla Ulusal Mücadele. Retrieved from <http://www.masak.gov.tr/en/Board/presentation.htm>

Riaño, J. and Hodess, R. (2008) Bribe Payers Index 2008. Transparency International, Berlin, Germany. 
Rodriguez, D., Waite, G. and Wolfe, T., eds. (2005). The global corruption report 2005. Retrieved from

<http://www.transparency.org/publications/gcr/download_gcr_2005\#download> on 8 March 2011.

Seidman, J. S. (December 1939). Catching up with employee frauds. The Accounting Review, Part 1, 14(4), p.415.

Sohail, M. and Cavill, S. (September 2008). Accountability to prevent corruption in construction projects. Journal of Construction Engineering and Management, 134(9), p.729-738.

Stansbury, N. (2005). Exposing the foundations of corruption in construction, global corruption report special focus: Corruption in construction and post conflict reconstruction, Pluto, London. Journal of Construction Engineering and Management, 124(9)

The American Institute of Certified Public Accountants Committee of Sponsoring Organizations of the Tread way Commission. (1992). Internal Control Integrated Framework. New York.

The Chartered Institute of Management Accountants (2001). Fraud risk management - A guide to good practice. Retrieved from <http://www.cimaglobal.com> on 11 March 2011.

The Chartered Institute of Management Accountants (2009). Fraud risk management - A guide to good practice. Retrieved from <http://www.cimaglobal.com/Documents/ImportedDocuments/cid_techguide_fra ud_risk_management_feb09.pdf.pdf> on 11 March 2011.

Transparency International (2009). Business principles for countering bribery - a multi-stakeholder initiative led by transparency international. Retrieved from <http://www.transparency.org/content/download/43008/687420> on 24 March 2011.

Transparency International (2010). Corruption Perceptions Index 2010. Retrieved from <http://www.transparency.org/content/download/55725/890310> on 11 March 2011. 
Türk Müteahhitleri Birliği (July 2009) İnşaat Sektörü Analizi. Retrieved from <http://www.tmb.org.tr/arastirma_yayinlar/bulten_temmuz_son_2009.pdf > on 11 March 2011.

United Nations Office on Drugs and Crime, Vienna. (2004). United Nations convention against corruption. New York.

Welch, S., Holmes, S., Strawser, R. (1996). The inhibiting effect of internal auditors on fraud. Internal Auditing, 12 (Fall), p.23-32.

Wells, J.T. (March, 2003). How to Screen Job Applicants to Avoid Potential Employee Fraud. Retrieved from

<http://www.acfe.com/resources/view.asp?ArticleID=19> on 11 March 2011.

World Economic Forum in partnership with Transparency International and the Basel Institute on Governance (2005). Partnering Against Corruption Principles for Countering Bribery. Retrieved from <http://www.gopacnetwork.org/Docs/Main/PACI_Principles_EN.pdf> on 11 March 2011. 


\section{APPENDIX A: Sample Questionnaire}

This research is performed by Assoc. Prof. Dr. Murat Gündüz and Oytun Önder who is a graduate student in Construction Management section of Civil Engineering Department of Middle East Technical University. The purposes of this questionnaire are to understand the awareness of Turkish construction companies against fraud, to understand present proactive measures of Turkish construction companies to prevent fraud, to understand common fraud types that Turkish construction companies face with and finally to understand reactions of Turkish construction companies after internal fraud incidents.

This questionnaire will take 15 minutes at most. We are very grateful for your time and your interest in our questionnaire.

Your answers and survey results will be used for academic purposes and will be kept anonymously.

If you want to ask any questions, you can contact to us via correspondence addresses depicted below.

Murat GÜNDÜZ

Assoc. Prof. Dr.

Phone: 03122105422

Fax: 03122105401

E-mail: gunduzm@metu.edu.tr

\section{Oytun ÖNDER}

Graduate Student

Phone: 05326226901

Fax: 03124417486

E-mail: oytunonder@gmail.com 
1) What is your position in the company?

○ Owner / Shareholder / Member of Board of Directors

○ General Manager / General Coordinator

$\circ$ Project Manager

$\circ$ Site Chief

○ Technical Office Chief

$\circ$ Administration Manager / Procurement Manager

○ Internal Audit Manager / Internal Auditor

$\circ$ Other, please indicate

2) How many people are working in central office/s of your company?
$\circ 1-25$
○ $26-50$
$\circ>50$

3) What is the average annual revenue of your company from construction projects in the last three years? (In TL)
$0<15,000,000$
○ $15,000,000-100,000,000$
o $>100,000,000$

4) Please indicate the average number of projects simultaneously conducted by your company in the last three years.
$\circ 1-3$
○ 4-6
$0>6$ 
5) Please indicate most frequent type of contracts that were/have been conducted by your company in the last three years.

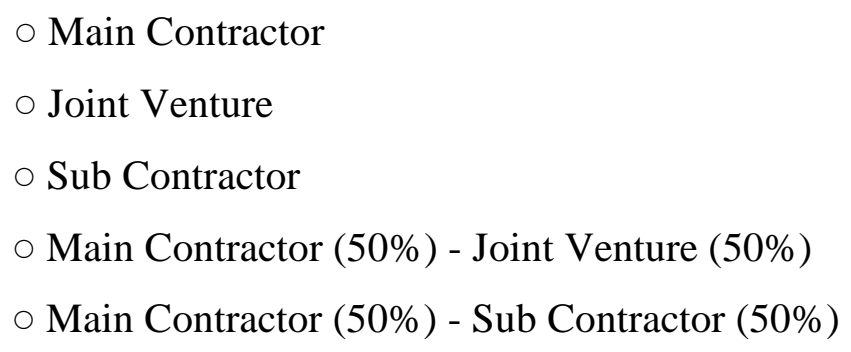

6) How many of the following types of the projects were/have been conducted by your company in the last three years?

i) Superstructure (Residential buildings, hospitals, schools, renovations, etc.)

ii) Infrastructure (Roads, water supply, sewers, power grids, telecommunications, etc.)

iii) Industrial (Medicine, petroleum, chemical, power generation, manufacturing, etc.)

iv) Mechanical Works (Plumbing, HVAC, etc.)

v) Electrical Works

vi) Airports, Seaports, Railways

vii) Dams, Hydro-electric Plants

$$
\begin{aligned}
& \circ 1 \\
& \circ 2 \\
& 0>3
\end{aligned}
$$

7) Has your company carried out a construction project abroad in the last three years?

$$
\begin{aligned}
& \circ \text { Yes } \\
& \circ \text { No }
\end{aligned}
$$


8) Do you think that your company is under the risk of internal fraud?

$\circ$ Yes

$\circ$ No

9) Which level of the employees is closer to perpetrate internal fraud?

o Senior Management (Management Board, General Director, CEO, CFO, etc.).

$\circ$ Middle Management (Managers, etc.)

○ Junior Management (Chiefs, In Charges, etc.)

○ Blue Collared (Workers)

$\circ$ Do not know

$\circ$ Do not want to answer

10) What types of preventive measures are likely to prevent internal fraud in construction sector? (On a scale of 1 to 3 , where 1 is "not at all likely" and 3 is "extremely likely")

\begin{tabular}{|l|l|l|l|}
\hline & 1 & 2 & 3 \\
\hline Implementing segregation of duties principle & & & \\
\hline Internal audit & & & \\
\hline Internal trainings & & & \\
\hline Management reviews - periodic reporting & & & \\
\hline External audit & & & \\
\hline Periodic rotation of employees & & & \\
\hline $\begin{array}{l}\text { Encouragement and protection of whistleblowers and } \\
\text { whistle-blowing hotlines }\end{array}$ & & & \\
\hline
\end{tabular}


11) What types of internal frauds are likely to occur in construction sector? (On a scale of 1 to 3 , where 1 is "not at all likely" and 3 is "extremely likely")

\begin{tabular}{|l|l|l|l|}
\hline & 1 & 2 & 3 \\
\hline Financial statement fraud & & & \\
\hline Cash theft & & & \\
\hline Inventory theft & & & \\
\hline Data theft & & & \\
\hline Misuse of an inventory or an asset of the company \\
\hline $\begin{array}{l}\text { Invoices received for fictitious goods or services, } \\
\text { inflated invoices }\end{array}$ & & & \\
\hline $\begin{array}{l}\text { Reimbursement of fictitious or inflated business } \\
\text { expenses by an employee }\end{array}$ & & & \\
\hline Bid rigging & & & \\
\hline Kickback/bribe taken by employee & & & \\
\hline Ghost employee & & & \\
\hline Falsified working hours & & & \\
\hline
\end{tabular}

12) Does your company permit/encourage facilitation payments for nonfirm processes such as custom processes, license application, etc.?
○ Yes
$\circ$ No
$\circ$ Do not know
$\circ$ Do not want to answer 
13) Which of the following actions can be acceptable in order to maintain the company's survival during an economic crisis?

\begin{tabular}{|l|l|l|l|}
\hline & Yes & No & $\begin{array}{l}\text { Do not } \\
\text { want to } \\
\text { answer }\end{array}$ \\
\hline $\begin{array}{l}\text { Making payments to employers to protect } \\
\text { the present work or win new businesses }\end{array}$ & & & \\
\hline $\begin{array}{l}\text { Giving presents to employers to protect the } \\
\text { present work or win new businesses }\end{array}$ & & & \\
\hline $\begin{array}{l}\text { Organization of entertainments for } \\
\text { employers to protect the present work or } \\
\text { win new businesses }\end{array}$ & & & \\
\hline $\begin{array}{l}\text { Misrepresenting financial status of the } \\
\text { company to the market }\end{array}$ & & & \\
\hline
\end{tabular}

14) When was the soonest fraud risk assessment project applied on your company?
$0<6$ months
$\circ 6$ months -1 year
$\circ>1$ year
○ Never
$\circ$ Do not know

15) Does your company have any of the following anti-fraud measures in place? 


\begin{tabular}{|l|l|l|l|}
\hline & Yes & No & Do not know \\
\hline Internal audit & & & \\
\hline External audit & & & \\
\hline Code of business conducts & & & \\
\hline Legal counsel & & & \\
\hline Periodical legal due diligence & & & \\
\hline $\begin{array}{l}\text { Internal trainings (fraud } \\
\text { awareness, ethical rules, etc.) }\end{array}$ & & & \\
\hline Whistle-blowing hotline & & & \\
\hline
\end{tabular}

16) Are background checks performed for potential vendors?
$\circ$ Yes
$\circ$ No
$\circ$ Do not know

17) Does the company have different parties for the processes of purchase order and vendor selection?
$\circ$ Yes
$\circ$ No
$\circ$ Do not know

18) Are the purchase invoices approved by the personnel/department who gave the purchase order?
$\circ$ Yes
$\circ$ No
$\circ$ Do not know 
19) Does your company have any requirement for obtaining bids from multiple vendors?
$\circ$ Yes
$\circ$ No
$\circ$ Do not know

20) Does your company have a list of qualified/selected vendors?
$\circ$ Yes
$\circ$ No
$\circ$ Do not know

21) While hiring a new employee, which of the following checks/verifications are applied by your company?

\begin{tabular}{|l|l|l|l|}
\hline & Yes & No & Do not know \\
\hline Past employment verification & & & \\
\hline Criminal conviction checks & & & \\
\hline Reference checks & & & \\
\hline $\begin{array}{l}\text { Education and certificate } \\
\text { verification }\end{array}$ & & & \\
\hline
\end{tabular}

22) Has your company been a victim of any sort of internal fraud in the last three years?
$\circ$ Yes
$\circ$ No
$\circ$ Do not know
$\circ$ Do not want to answer 
23) Please indicate which of the following/s has occurred in your organization in the last three years?

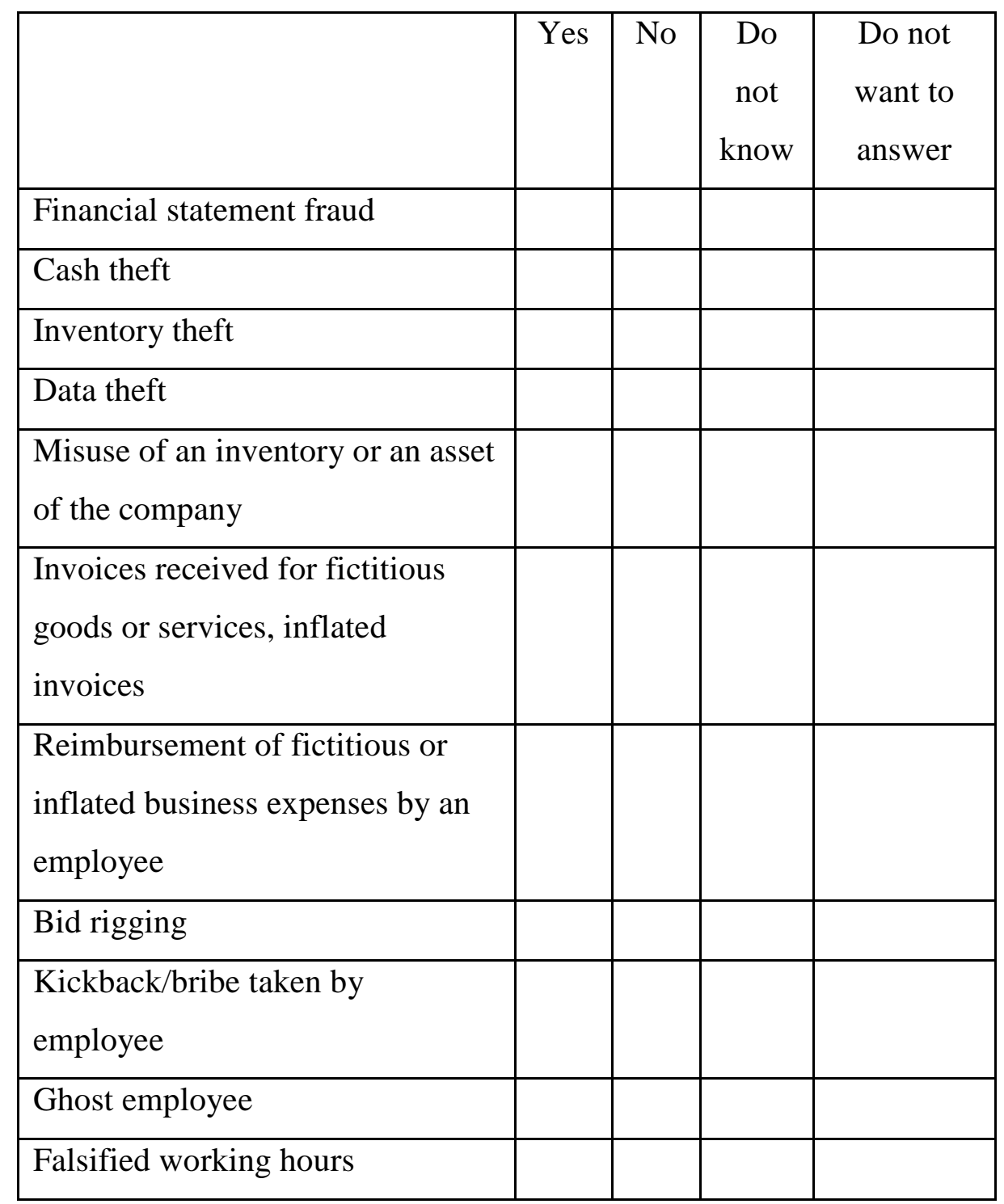


24) If your company has faced with an internal fraud/s, what action/s did you/management take?

\begin{tabular}{|l|l|l|l|l|}
\hline & Yes & No & $\begin{array}{r}\text { Do } \\
\text { not } \\
\text { know }\end{array}$ & $\begin{array}{c}\text { Do not } \\
\text { want to } \\
\text { answer }\end{array}$ \\
\hline Nothing & & & & \\
\hline Warned the employee & & & & \\
\hline $\begin{array}{l}\text { Dismissed the responsible } \\
\text { employee/s }\end{array}$ & & & & \\
\hline $\begin{array}{l}\text { Prosecuted the responsible } \\
\text { employee/s }\end{array}$ & & & & \\
\hline $\begin{array}{l}\text { Demanded restitution but did not } \\
\text { cover the damage }\end{array}$ & & & & \\
\hline $\begin{array}{l}\text { Demanded restitution and covered } \\
\text { the damage }\end{array}$ & & & & \\
\hline
\end{tabular}

